TAJIKISTAN UNRAVELLED:

\title{
THE STATE RESETTLEMENT OF CITIZENS
}

\author{
BY \\ NADINE WALICKI
}

\section{THESIS}

Submitted in partial fulfillment of the requirements for the degree of Master of Arts in European and Russian Studies at the Graduate School of Carleton University

(c) Nadine Walicki 2006 


$\begin{array}{ll}\begin{array}{l}\text { Library and } \\ \text { Archives Canada }\end{array} & \begin{array}{l}\text { Bibliothèque et } \\ \text { Archives Canada }\end{array} \\ \begin{array}{l}\text { Published Heritage } \\ \text { Branch }\end{array} & \begin{array}{l}\text { Direction du } \\ \text { Patrimoine de l'édition }\end{array} \\ \begin{array}{l}\text { 395 Wellington Street } \\ \text { Ottawa ON K1A ON4 }\end{array} & \begin{array}{l}\text { 395, rue Wellington } \\ \text { Ottawa ON K1A ON4 } \\ \text { Canada }\end{array}\end{array}$

Your file Votre référence

ISBN: 0-494-13425-9

Our file Notre référence

ISBN: 0-494-13425-9

NOTICE:

The author has granted a nonexclusive license allowing Library and Archives Canada to reproduce, publish, archive, preserve, conserve, communicate to the public by telecommunication or on the Internet, loan, distribute and sell theses worldwide, for commercial or noncommercial purposes, in microform, paper, electronic and/or any other formats.

The author retains copyright ownership and moral rights in this thesis. Neither the thesis nor substantial extracts from it may be printed or otherwise reproduced without the author's permission.
AVIS:

L'auteur a accordé une licence non exclusive permettant à la Bibliothèque et Archives Canada de reproduire, publier, archiver, sauvegarder, conserver, transmettre au public par télécommunication ou par l'Internet, prêter, distribuer et vendre des thèses partout dans le monde, à des fins commerciales ou autres, sur support microforme, papier, électronique et/ou autres formats.

L'auteur conserve la propriété du droit d'auteur et des droits moraux qui protège cette thèse. $\mathrm{Ni}$ la thèse ni des extraits substantiels de celle-ci ne doivent être imprimés ou autrement reproduits sans son autorisation.
In compliance with the Canadian

Privacy Act some supporting forms may have been removed from this thesis.

While these forms may be included in the document page count, their removal does not represent any loss of content from the thesis.
Conformément à la loi canadienne sur la protection de la vie privée, quelques formulaires secondaires ont été enlevés de cette thèse.

Bien que ces formulaires aient inclus dans la pagination, il n'y aura aucun contenu manquant.

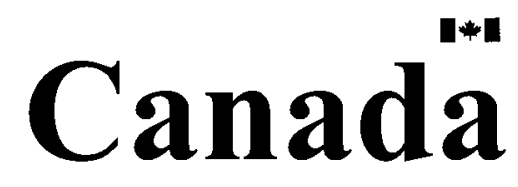




\begin{abstract}
The state resettlement of citizens in Tajikistan has resulted in a confused situation. Designed to strengthen the economy and prevent suffering from natural disasters, the Tajik state has failed to implement resettlement policy as planned due to low financial and institutional capacity. The state nonetheless exhibits itself as a "strong-weak" state, with fluctuating capacities. The major actors in this resettlement are state officials, resettlers and representatives of international organizations. Members of each of these groups exhibit a range of responses, play multiple roles and have different experiences in resettlement. As such, none can be considered a unitary actor. Despite their fragmentation, these groups are interdependent and shape each other's opportunities and outcomes. Their interdependent relationship reveals power as a dispersed and ubiquitous phenomenon in Tajikistan. It also shows that resettlement is a dynamic process changing over time, not necessarily tending towards one fixed destination.
\end{abstract}




\section{ACKNOWLEDGEMENTS}

I owe a great deal of thanks to the International Organization for Migration (IOM) for helping make this research study happen. Without the financial and institutional support of this organization, I would not have been able to complete this study to the same degree. In particular, I would like to thank Heather Salfrank who first sparked my interest in the topic and later guided me in the fieldwork, all the while providing insightful comments and suggestions.

Above all, I would like to thank my father and Jamison for their ongoing support of my travels and this thesis. Their encouragement and interest in this project was a constant source of motivation that I will always remember. 


\section{TABLE OF CONTENTS}

\section{CHAPTER 1}

INTRODUCTION

CHAPTER 2

A FRAGMENTED ACTOR: THE STATE IN RESETTLEMENT 31

CHAPTER 3

IMPORTING THEIR INFLUENCE: INTERNATIONAL ACTORS IN TAJIKISTAN 76

CHAPTER 4

SHIFTING GROUND: RESETTLERS AND RESETTLEMENT. 106

CHAPTER 5

CONCLUSION 143 


\section{LIST OF FIGURES}

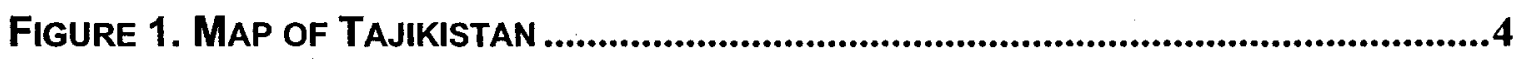

Figure 2. Geographical Distribution of Resettled Households........................35

Figure 3. MAgnitude of RESETtLement: SEnding Districts...................................35

Figure 4. Magnitude of Resettlement: Receiving Districts................................36 


\section{LIST OF APPENDICES}

APPENDIX 1. INTERVIEW QUESTIONS FOR GOVERnMENT OfFICIALS......................175

APPENDIX 2. INTERVIEW QUESTIONS FOR RESETTLERS..................................177

APPENDIX 3. INTERVIEW QUESTIONS FOR REPRESENTATIVES OF INTERNATIONAL

ORGANIZATIONS....................................................................................181

vi 


\section{CHAPTER 1 \\ INTRODUCTION}

Flying through the Pamir Mountains in a small aircraft, I could see details of the Tajik landscape that were invisible from the roadside. The brown sandy mountains were sparsely speckled with trees. The contour of the mountain rock face seemed to have emerged from a woodcarver's tool. Patches of green tiny villages were interspersed between the mountains. The villages appeared isolated from any access road.

I commented on the beauty of the mountains to my colleague. She turned to me and reflected "it's hard to believe that something so beautiful can cause so much harm". Indeed, mountains pose serious challenges for Tajikistan. The mountains are ubiquitous, covering over ninety per cent of the territory. Telephone communication and transport between different regions is generally difficult. Two key mountain passes, including their roads, close during the winter. The closure further isolates the northern and eastern regions from the central and southern regions. Most devastatingly, Tajikistan is host to annual natural disasters such as avalanches, earthquakes, landslides and floods.

In an attempt to manage natural disasters before they occur, as well as address population loss and a weakened economy following the civil war, the Tajik government devised population resettlement schemes starting in 1999. Since then, the government has been moving people from locations with a serious threat of natural disaster, overpopulated areas and places with an inadequate amount of arable land to sites with available land that the state has 
deemed to be safe from natural disasters. The state organizes, finances and oversees the resettlement process and provides resettled households with transportation to the resettlement area, as well as a plot of land and financial assistance at their new home.

The resettlement policy documents outline a straightforward household resettlement plan. State agents in departure areas are to compile a list of resettlers, and organize and transport them to the resettlement area. State agents in destination areas must prepare water, electricity, education, health and communication infrastructure, as well as integrate resettlers upon arrival. Despite the clear delineation of responsibilities, this resettlement has not produced straightforward results. On the contrary, resettlement has resulted in a confused and complex situation where the state, international organizations and resettlers are simultaneously shaping and hindering each other's opportunities.

This study focuses on these government resettlement schemes. The main players in resettlement are the state, representatives of international organizations and resettlers. By looking at how this policy is being implemented in practice and how each of the players is acting, I will expose the various notions of power at work in Tajikistan. I will also make conclusions about the state, international organizations and resettlers in Tajikistan. Recent studies on Tajikistan focus on the civil war, the presidency, the Soviet legacy, gender relations and the role of religion. This work fills the research gap on contemporary Tajikistan and adds to the literature on Central Asian and postCommunist states and power. 
Tajikistan is a landlocked country located in the southeastern corner of Central Asia ${ }^{1}$. Kyrgyzstan lies to the north, Uzbekistan to the west, Afghanistan to the south and China to the east. In 2000 , the country was divided into five oblast-level units: 1) Dushanbe ${ }^{2}$, the capital and largest city of Tajikistan; 2) Sugd oblast (formerly Leninabad oblast); 3) Direct Rule District (DRD); 4) Khatlon oblast (formerly Kurgan-Tyube and Kulyab oblasts), and 5) an autonomous region, Gorno Badakhshan Autonomous Oblast (GBAO). Most investments went to northern Sugd province during Soviet times. As a result it is richer and more industrialized than other regions. The capital city, Dushanbe, as well as main aluminum plants are located in the Direct Rule District. Southern Khatlon province is agricultural and impoverished, though less mountainous than the other regions. Eastern Gorno Badakhshan is the largest, most isolated region with few roads.

\footnotetext{
${ }^{1}$ For the purposes of this paper 'Central Asia' refers to the five post-Soviet states of Kazakhstan, Kyrgyzstan, Tajikistan, Turkmenistan and Uzbekistan.

${ }^{2}$ Since I conducted the research for this study in Russian, I will use the transliteration of Russianstyle place names and terminology.
} 


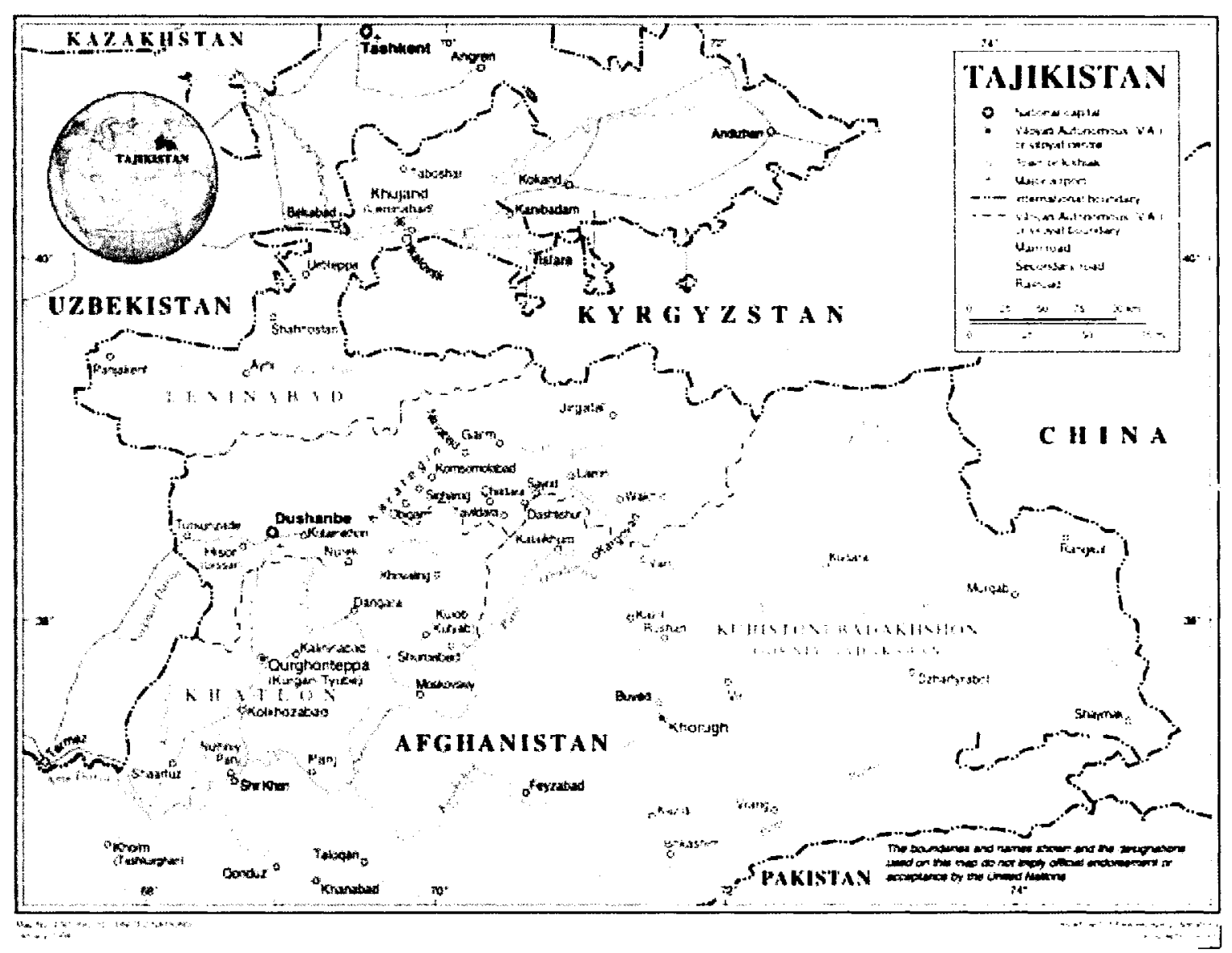

Figure 1. Map of Tajikistan ${ }^{3}$

According to the results of the 2000 census, Tajikistan has a population of 6.1 million people (Rowland 2005, 204). Tajiks constitute eighty per cent of the total population, Uzbeks fifteen per cent, Russians one per cent and Kyrgyz one per cent (ibid., 209). Most of Tajikistan's population is concentrated in the western half of the country, owing to the rugged mountainous terrain of the eastern Gorno Badakhshan region. Tajiks are spread fairly evenly throughout the country but other ethnic groups tend to be concentrated in certain areas. For

\footnotetext{
${ }^{3}$ United Nations. 1 October 1997. Cartographic Section. "General Map of Tajikistan." Internet. Available from http://www.un.org/Depts/Cartographic/map/profile/tajikist.pdf; accessed 21 December 2005.
} 
example, Pamiris ${ }^{4}$ are found in eastern Gorno Badakhshan province, Uzbeks are found mainly in southwestern Khatlon province and northern Sugd province, while Kyrgyz are found mainly in northern Sugd province and eastern Gorno Badakhshan province. Since 1989 there has been an increase in rural population and a decrease in urban population, which has been accompanied by a decline in urbanization (Rowland 2005, 210).

Tajikistan is a unique case among the former Soviet republics. Embroiled in a civil war from 1992 to 1997 , it underwent a sustained, large-scale, violent conflict after independence. The only other former Soviet republic that faced civil war after independence was Moldova. Scholars identify many factors that sparked the war, including nationalist aims, political struggles, religious differences and regional agendas. Adding to the complexity of the situation, external actors such as Iran, Russia and Uzbekistan supported certain groups during the war. The war ended with a United Nations (UN) brokered peace agreement. According to this agreement, opposition parties are guaranteed thirty percent of the top government posts.

The apparent success of international peacemaking to end the war also makes Tajikistan a unique case. Multilateral peacemaking has failed to solve many conflicts around the world including those in Yugoslavia, Rwanda and Somalia. One reason for this is a lack of cooperation and coordination among the many mediators involved in the process. International relations specialist Tetsuro lji argues that in the case of Tajikistan, close cooperation and effective

\footnotetext{
${ }^{4}$ Pamiris adhere to the Ismaili sect of the Muslim faith, derived from the Shiite, and speak Pamiri, a0 language incomprehensible to Tajiks. They consider themselves "religiously" and "nationally" different from Tajiks, the majority of whom practice Sunni Islam (Akcali 2003, 421).
} 
coordination on the part of a wide variety of actors involved, and the fact that these actors played complementary roles, led to the successful implementation of the peace agreement (lji 2005, 189). Russia and Iran were the major external actors in building the peace, while the UN, Organization for Security and Cooperation in Europe (OSCE) and Commonwealth of Independent States (CIS) were the major intergovernmental players. All of these external actors had converging interests: none wanted the war to continue and all hoped to be seen as a contributor in settling it (ibid., 191). Therefore the interested states supported the mediation process, reached a consensus on how to terminate the war and the UN acted to make this a reality.

Although the UN power-sharing agreement has generally been respected, the situation has been changing since 2004. In January 2004 President Rakhmonov replaced senior government officials from political parties other than his own with members of his own party, reducing other parties' share of top posts to five per cent (Human Rights Watch 2005). Also in January 2004, the Supreme Court sentenced Shamsuddin Shamsuddinov, deputy Chairman of the opposition Islamic Renaissance Party (IRP) to sixteen years in prison on charges of polygamy, organizing an armed criminal group during the civil war and illegally crossing the border. Likewise in 2005, Mahmadruzi Iskandarov, the leader of the opposition Democratic Party (DP), was sentenced to twenty-three years in prison for charges relating to terrorism and embezzlement, a move that critics say was politically motivated (British Broadcasting Corporation 2005).

The economic and social effects of the civil war were devastating. At 
independence in 1991, Tajikistan was the poorest Soviet republic. No longer able to count on monetary transfers from Moscow, and with disrupted trade relations and a fall-off in investment, economic growth was seriously impaired. The civil war only served to exacerbate the situation. Widespread destruction of property and neglect of infrastructure left a shortage of housing, resources and employment for the general population. The war cost CAD $\$ 8$ billion $^{5}, 35,000$ homes were destroyed, 50,000 people died, 437,000 people left Tajikistan and 600,000 people were displaced internally within Tajikistan (Rowland 2005, 207208). Emigration deprived the republic of needed skilled workers and professionals and labourers were lost that could not be replaced. As a result, many factories closed down. A 2003 World Bank study concluded that sixtyeight per cent of the population in Tajikistan lives below the poverty line on less than CAD $\$ 2.50$ per day. As an International Crisis Group (ICG) report explained, "[p]overty is evident everywhere...For most people, life in Tajikistan is a constant struggle for survival in difficult economic circumstances" (ICG 19 May 2004, 19).

In addition to a poor economic situation, life in Tajikistan is also fraught with paradox. More than sixty per cent of all Central Asian water resources originate in Tajikistan, however there is a shortage of drinking and irrigation water in Tajikistan. After years of neglect and looting during the civil war as well as lack of funds for maintenance, the water system is inefficient and serves only certain localities. The facilities available for treating and distributing water within Tajikistan are "pitiful" (IWPR 2005b). Indoor plumbing exists only in the major cities, otherwise people access water from communal water pumps. Analyses of

\footnotetext{
${ }^{5}$ All currencies in this study have been converted to Canadian dollars for consistency.
} 
water samples collected throughout Tajikistan in 2002 showed that over forty per cent of the water was not safe for drinking (World Bank 2005, 32). In its 2003 study on living standards Tajikistan, the World Bank found that thirty-three per cent of the population had access to chlorinated piped water and twenty-nine per cent drank water from a spring or a well (ibid., 30). Other people drank from rivers, reservoirs or above-ground cement irrigation canals. Outbreaks of waterborne diseases remain commonplace. The World Health Organization reported in 2003 that the lack of safe drinking water in Tajikistan is the principal cause of sixty per cent of diseases, particularly cholera, typhoid, diarrhea, dysentery, diphtheria and hepatitis (United Nations Development Program 2003, 19; Eurasia Net 2003).

The irrigation water system is also in poor shape. According to the United Nations Development Program (UNDP), "around 84 per cent of all water used in Tajikistan is consumed by the agricultural sector, yet only half of this is thought to reach the crops - the rest is lost to evaporation and inefficiencies in the water transport infrastructure" (UNDP 2003, 18). The state pumps water to elevated areas "to keep the rural populace occupied," but this is unprofitable when it lifts the water over two elevation levels to people living in mountainous areas (ICG $2005,29)$. Continued neglect of the pumping systems may cause them to break and this could lead to conflict in rural areas. Further complicating the issue is that cotton traders may be using their political influence to keep areas under their control irrigated regardless of the cost to the state, and in this way they are depriving others of scarce water sources. The International Crisis Group 
concludes, "Even such a seemingly mundane matter as water pumping is fraught with economic, political and social peril" (ICG 2005, 29).

Another paradox of life in Tajikistan is that agriculture is both the foundation of the economy and employment despite the fact that irrigated land covers less than ten per cent of Tajikistan's territory. Although sixty-five per cent of the population depends on agriculture for their livelihood (UNDP 2003, 18), much of the rural population continues to rely on international food aid (ICG 19 May 2004, 1). This is because of the lack of regular irrigation water, but also because of poor soil conditions. The ICG explains:

\begin{abstract}
Ironically water infrastructure shortcomings mean land receives too much water. As it becomes saturated, the water table rises, carrying minerals to the surface. The land becomes swampy, and the water gradually evaporates, leaving a crust of salt behind. High levels of salt are toxic and hinder plant absorption of water through osmosis. Salinization likewise puts a further strain on water use, as farmers attempt to flush out their fields by applying even more water. Eventually the land becomes useless for agriculture (ICG 2005, 29).
\end{abstract}

Lack of crop rotation and land tenure policies that offer farmers few incentives to invest in their land also contribute to poor land quality.

Citizens face problems with water and land because the state controls these resources and the cotton industry takes priority. Cotton is the overwhelmingly dominant cash crop in the agricultural sector and one of the main export commodities accounting for almost thirty percent of the country's export earnings (World Bank 2005, 18). Three quarters of Tajikistan's farmlands are dedicated to growing cotton, as is almost half of Tajikistan's labour force. To ensure these profits, the state directs water first to cotton fields. Any water left over is then sent to communal water pumps. Likewise the most fertile land is relegated to the cotton industry. Private farms are also forced to plant cotton and 
if they refuse, inputs such as water, seeds and fertilizer may be withheld by the local authorities and suppliers (UNDP 2003, 38). Taken altogether, the state reliance on the cotton industry is a 'cotton monoculture' (ICG 2005).

This monoculture is for the benefit of the state and to the detriment of the general population. Although the state has grown cotton in Tajikistan since Soviet times, a private gin sector emerged in the early 1990 s when government funding of the cotton sector became unsustainable. These gins use the money paid by their foreign partners, for example Paul Reinhart or Credit Suisse-First Boston, to advance credit to farmers to buy inputs. In return, farmers deliver a fixed amount of cotton to the gin. The price of the inputs is inflated while the cotton purchase price is depressed. The result is that Tajik cotton farmers now owe an estimated CAD $\$ 255$ million to the middlemen gins (Peel 2005). Millions of the rural poor work for little or no reward growing and harvesting the crop. Farmers who grow cotton are more likely to be poor than those who grow potatoes, despite the fact that cotton is the number one cash crop (ICG 2005, 9). The considerable profits go to the state or small elites with powerful political ties.

With such poor living conditions and bleak employment prospects, many Tajiks have left Tajikistan to search for work. Labour migration emerged as a stabilizing factor to offset the effects of economic crisis after independence. It was initially linked to the streams of refugees who fled Tajikistan during and after the civil war. Now labour migration is one of the main features of contemporary Tajikistan affecting the domestic economy, labour force and family life (International Organization for Migration 2003, 5). The International Organization 
for Migration (IOM) estimates that upwards of 600,000 men leave Tajikistan each year in search of casual seasonal employment in the Russian Federation and other parts of the CIS (ibid. 2003, 6). The Russian Federation attracts the majority of Tajik labour migrants because Tajiks need not present a visa to enter Russia, most Tajiks speak Russian and there is a Tajik diaspora there (ibid., 22). Tajik labour migrants are mainly men who work predominantly in the construction industry, the food industry, the service industry and chemical plants (ibid., 24). Two age groups mainly pursue labour migration, 20-29 years of age and 40-49 years of age, and their main purpose in going abroad is to earn money for family celebrations and housing (ibid., 26). Labour migrant remittances total twenty per cent of the Gross Domestic Product (GDP) and serve as the main source of income for most families (ICG 19 May 2004, 12). In 2002, the combined value of cash and goods flowing into Tajikistan through its migrant workers was estimated at CAD\$230-265 million (IOM 2003, 94).

Russia and Tajikistan have more in common than Tajik labour migrants. Viewing the rugged Tajik-Afghan frontier as a possible security risk that an impoverished Tajikistan could not safeguard on its own, Russia stayed on after the collapse of the Soviet Union to help Tajikistan patrol this 1,206 kilometre border. This border had been "fairly porous" during much of the Soviet decline and ceased to be an effective barrier to traffic from Afghanistan after 1991 (Merry 2004, 292). This extra Russian manpower notwithstanding, Tajikistan emerged as a major transit country for narcotics produced in Afghanistan during the 1990s. Tajikistan is still a major channel for drug trafficking to Russia and 
Europe (Human Rights Watch 2004). Russian soldiers under Moscow's direct control guarded the border until 2005 when the task was handed over to Tajik border guards (British Broadcasting Corporation 2005c). Russian soldiers are still present in Tajikistan as Russia officially opened a military base in Dushanbe in 2005.

This issue highlights the importance of international actors in Tajikistan, especially since the events of 11 September 2001. After 11 September 2001, the security of Central Asia, including Tajikistan, became a priority for many states in the anti-terrorist coalition. Specifically in Tajikistan, member states of this coalition believe an effectively managed Tajik-Afghan border implies the containment of drug trafficking flows as well as the containment of people belonging to radical Islamist groups arriving from Afghanistan. Research Fellow in Central Asian Studies Annette Bohr argues that Tajikistan ousted Russian troops because offers from the United States to assist with border management were more attractive.

Possibly emboldened by the U.S. pledge of nearly $\$ 2$ million worth of equipment to Tajik Border Service in addition to professional training for army officers, Tajik border officials stated on several occasions in 2003 that Tajikistan was ready to dispense with Russian troops that have been guarding country's border with Afghanistan (Bohr 2004, 490).

However, as political scientist Roger McDermott comments, Tajikistan wanted the Russian soldiers to leave the border, but Russian assistance to continue.

The public show of asking the Russian border service to hand over control of the border areas to Tajik border troops has now given way to recognition of the need for Russian expertise in developing the Tajik State Border Guard Committee (McDermott 2005a).

Following 11 September 2001, Tajikistan also had significant offers from the European Union and international organizations to assist with border 
management. President Rakhmonov accepted these offers of assistance and realizing Tajikistan's significant geopolitical position and that he is working with low state capacity, he began to appeal for assistance in other problem areas.

As a result, international actors emerged as significant players in the state-building process in Tajikistan. This is in part due to President Rakhmonov's realization that Tajikistan is unable to perform all state tasks independently. As, Erika Weinthal explains, "post-Communist states may encourage international involvement to perform what are ostensibly state tasks because they are weak and poor" (Weinthal 2004, 251). Due to their unique position outside of the citizenry and outside of the state, these international actors are able to influence both state policy and citizen behaviour. With actors from various countries and with different interests and priorities, the state building process in Tajikistan is influenced as much from without as it is from within (Grzymala-Busse and Jones Luong 2002, 531).

For this study, I define state capacity as the ability of the state to implement policies in order to achieve its economic, social or political goals (Barkey and Parikh 1991, 526; Weinthal 2004, 247). State capacity is usually equated with institutional capacity, but it also has technical, fiscal and organizational dimensions. State capacity to carry out objectives is a product of the state's institutional structure, but it is also a product of the state's ability to mobilize external resources like expertise and capital (Barkey and Parikh 1991, 534). State capacity is acquired through institutions such as the bureaucracy, or through resources such as external ties to expertise and finance capital. 
Originally used by sociologists Karen Barkey and Sunita Parikh to articulate comparative perspectives of the state, this definition of state capacity is advantageous for two reasons. A review of the literature for this study uncovered no research on state capacity in Tajikistan. This definition is useful since it focuses on state policy, which is the case study of this paper. Also, the same definition was used by Pauline Jones Luong, Kelly McMann and Erika Weinthal in their studies of post-Soviet Central Asian states. Since I refer to their conclusions in this paper, I will use the same definition for consistency.

Several scholars argue that Tajikistan is a weak state. According to international relations specialist Sally N. Cummings Tajikistan is weak because its economy is weak and the president takes repressive action against citizens. Offshoots of low economic growth such as drug trafficking and terrorist insurgencies have weakened Tajikistan even more, as has corruption. President Rakhmonov has pointed to these issues as justification in using repressive measures against citizens, which also reveal the weak character of the state (Cummings 2002, 12). Historian Muriel Atkin also concludes that Tajikistan is a weak state (Atkin 2002, 111). She agrees a weak state is that with a weak economy and adds that such states lack legitimacy and vision. Atkin writes,

The government's writ barely applies in some parts of the country. Even apart from that, the government is in such a weak financial position that it cannot afford to do what needs to be done to address the country's problems and has little vision of what the effective remedies might be (Atkin 2002, 97).

Atkin also highlights the limited ability of the state to regulate the economy and to provide adequate social protection. She adds that the Tajik state is weak because of its "incompetent powers of coercion" and because security bodies are 
poorly paid and ill equipped (ibid., 99). Shirin Akiner writes, "The Tajik state today is as weak and impotent as is society as a whole...it is scarcely able to discharge the basic functions that are expected of government" (Akiner 2002, 183). These views suggest the lack of any evidence of a strong Tajik state.

More recent studies have characterized the Central Asian states as "strong-weak" states. Political scientist Kelly McMann coined the term in her study of non-governmental organizations in Kyrgyzstan. According to her, the Kyrgyz state is strong since it possesses the monopoly on a relative wealth of resources that the civic sphere requires to function. But the state is simultaneously weak as exhibited by a lack of capacity to fulfill policy objectives and cooperate with civic organizations (McMann 2004, 239). Pauline Jones Luong extends this argument to the region as a whole and characterizes all Central Asian states as "strong-weak states" (Jones Luong 2004a, 280). She explains that Central Asian states are strong in the sense that they can shape citizens' expectations and opportunities by limiting their access to scarce resources. However, they are simultaneously weak since they can neither form coherent goals nor implement policies consistently and they harass, torture and imprison political opponents. As observed by Hannah Arendt, a state that continually uses coercion against citizens is actually relatively weak (Arendt $1970,4)$. Physical power and coercion can inflict terrible suffering, but they are not an effective source of stable social control and are therefore evidence of a weak state (Haugaard 2003, 109). Leaders have sought to maintain control over resource distribution networks and to limit democratization and this coupled with 
residual powers and low state capacity according to Jones Long, "has left the state in Central Asia both strong and weak" (Jones Luong 2004b, 280).

Other authors have documented this duality of states with respect to 'Third World' countries. Professor of international studies Joel Migdal acknowledged the "duality of states" in his study of strong states and weak societies in the "Third World,' which concluded that states have unmistakable strengths in penetrating societies and surprising weaknesses in effecting goal-oriented social changes (Migdal 1988, 9). This duality is apparent in Tajikistan where the state is a part of the daily life of citizens since it controls water and electricity provision, but is unable to implement its resettlement policy as planned.

These opinions on state strength in Tajikistan and Central Asia reveal several components of the definition of state strength and state weakness that will be used for this study. A weak state uses repressive measures against the citizenry and political opponents, is unable to form reasoned goals and implement policies consistently, and has a weak economy. A strong state can shape citizen's expectations, limit their access to scarce resources and can achieve policy goals. These definitions contain concrete criteria against which to measure state strength and weakness, making it useful for this study. Migdal adds that in cases of a strong state, the state gains compliance and participation from the population and the population accepts and approves the state's desired social order since it accepts the state's rhetoric (Migdal 1988, 32). Migdal's definition is especially helpful here as it deals directly with how citizens interact with the state, which will be investigated here. Therefore the definition of state 
strength that will be used here is a combination of that given by authors who have studied Central Asia cited above and Migdal's definition. This study will explore state strength according to implementation of resettlement policy.

Power is also a salient theme in this study. It is ubiquitous in relations among state officials, resettlers and representatives of international organizations, as well as in the experiences of each of these actors. Power theorists can be divided into those that believe power is based on consensus, those that believe power is based on conflict and those that believe it is both consensual and conflictual. Sociologist Talcott Parsons argues that power is "a consensual circulating medium" (Parsons in Haugaard 2002, 77). He continues that power is not just out there, it has to be created. Also, a gain in power is not necessarily at the expense of others. Although relations between agents may be based on inducement and coercion, he says ultimately one agent secures the compliance of another. In his view, power is not exercised when compliance is achieved through threat of superior force. Michel Foucault, on the other hand, argues that "the relationship of power may be an effect of a prior or permanent consent, but it is not by nature the manifestation of a consensus" (Faubion 1994, 340). Furthermore, one rarely has power without resistance.

Other theorists such as Mark Haugaard argue that the insistence on actual and observable conflict as essential to power is unsatisfactory. In his view, power can be consensual and not necessitate coercion, but most frequently it is both consensual and conflictual. Most social relations take place in the middle of 
compliance and coercion since peoples' motives are complex and because all social action has goal oriented and structural aspects.

Power theorists can also be divided between those that believe power is agent-centered and those that believe it is subject-centered. Agent-centered theorists such as Anthony Giddens argue the concept of power lies in the fact that things are given meaning and structure, allowing us to accomplish things we would otherwise not do. Power is generated in and through the reproduction of this structure. He writes,

\begin{abstract}
Agency is possible only because of resources which exist only as a potential facility because they are meaning given. The resources of a wealthy person or of a political leader exist only because of the meaning of money and authority. As the carrier of meaning, structure is central to the constitution of power resources. When a social agent acts, he or she draws upon certain resources to bring about certain situations which would not otherwise have occurred. When action takes place, an agent uses structure which, in the moment of being drawn upon, are recreated and, simultaneously with this act of structuration, the individual is facilitated in producing effects. In short, power is generated by structural reproduction which takes place in the moment of agency (Giddens in Haugaard 2002 149).
\end{abstract}

Structures signify and legitimize things and therefore facilitate agency and power. Another agent-centered power theorist Joseph Nye purports that power exists in both soft and hard formats. Hard power is economic and military power, and can also rest on inducement or coercion. Soft power is the ability to shape the preferences of others. "When you can get others to admire your ideals and to want what you want, you do not have to spend as much on sticks and carrots to move them in your direction. Seduction is always more effective than coercion and many values like democracy, human rights and individual opportunities are deeply seductive" (Nye 2004, 55). Soft power is more than just persuasion or the ability to move people by argument, it is the ability to attract, and its resources 
are those that produce such attraction (ibid., 30). Individuals are at the center of this perspective, which sees power circulating between individuals..

Subject-centered power theorists such as Michel Foucault stress that power is not the possession of an agent, but, rather, power is a dispersed, decentralized and ubiquitous phenomenon. It operates from below through lowlevel "capillary circuits" (Faubion 1994, xxv). Power is not a thing or institution. It exists only as an action on the actions of others, not on others themselves. According to Foucault,
the exercise of power...is a set of actions on possible actions; it incites, it induces, it seduces, it makes easier or more difficult; it releases or contrives, makes more probable or less; in the extreme, it constrains or forbids absolutely, but it is always a way of acting upon one or more acting subjects by virtue of their acting or being capable of action. A set of actions upon other actions...The exercise of power is a "conduct of conducts" and a management of possibilities." (ibid., 341).

Foucault's central claim is that power is productive as well as controlling, it produces, and constitutes subjects: it forges their characters and normalizes them, rendering them able and willing to adhere to norms by "systematic surveillance and self-surveillance" (Lukes 2005, 490). In this perspective, power exists outside of individuals, but it nonetheless determines the actions of individuals.

In addition to the definitions of power cited above, there are several other useful definitions in the literature. Giddens writes that power is a capacity to achieve outcomes. Steven Lukes agrees that power identifies a capacity. "It is a potentiality, not an actuality" (ibid., 478). It is a potentiality that may never be realized. The exercise or vehicle of that capacity is not power, only the potentiality is power. He adds that "sometimes...abstention or non-intervention 
can be a form of power" (ibid., 480). In addition, as stated earlier, Hannah Arendt argues that power is not violence. They are opposites. Where one rules the other is completely absent. According to Arendt, violent state repression of citizens signifies a loss of power rather than ultimate power (Arendt 1970, 10). Powerful states do not have to resort to violence in order to persuade their citizens to act in the ways preferred by the state.

For this study, power is defined as a capacity that may be utilized to secure an outcome. This capacity must be created through an action. It may exist outside and beyond the body of a person. Such an approach has numerous advantages for this study. It allows for the consideration of "inactive power" that derives from status (Lukes 2005,480 ). This is particularly useful as state officials are one of the actors being considered here. This definition also equates power with more than power resources, such as wealth and military forces. Such blatant power resources are not entirely relevant in this study, and as Lukes cautions "having the means of power is not the same as being powerful" (ibid., 478). More relevant are the more subtle aspects of power that give rise to habits, popular information, reactions and opinions.

The state resettlement of citizens in Tajikistan has resulted in a confused and complex situation. To begin, state agents, representatives of international organizations and resettlers are not homogenous actors. Resettlement programs move people mainly from mountainous areas to the valleys. Some state officials employ deceptive methods to convince people to move, while others provided citizens with an accurate depiction of the resettlement area. Greeted by a foreign 
climate, the absence of clean drinking water, infertile land, a lack of income opportunities and housing in need of serious repair in the resettlement area, many resettlers have moved elsewhere in Tajikistan or to Russia to find employment. Others have worked together to improve the access to safe water and electricity in the resettlement area. Still others wait for the state to live up to its promises. Some international actors provided assistance to resettlers, while others categorically refused.

Another aspect contributing to this confused situation is low state capacity. State officials report they do not have the funds necessary to create acceptable living conditions in resettlement areas or to enforce the obligatory residence rule. This low state capacity is undermining the objectives of the resettlement programs. With their expectations unmet, resettlers are advancing their own interests and articulating their autonomy from the state by leaving the resettlement areas and finding employment elsewhere. Many resettlers have financed their way back to their original place of residence in this manner, further undermining the policy objectives. The government gets away with low state capacity since there is no governmental accountability to society. It also gets away with low state capacity since international actors step in and provide resettlers with humanitarian aid, making up for the low capacity of the state.

Misinformation complicates the situation even more. State agents have different understandings about the repayment of financial assistance and the resettlement agreement. State agents also identify agricultural opportunities in resettlement areas based on Soviet-era harvest information and not on the 
contemporary reality. There is a large discrepancy between what state officials think living conditions are and the reality that resettlers report. For instance, state agents claim they inspected houses before resettlement, whereas resettlers reported that they arrived to find houses with cow manure inside and no windows or doors. Most potential resettlers do not have the means to investigate resettlement area conditions before moving and so they rely on information given by state officials, who often have not traveled to the resettlement areas due to a lack of state funds. Many resettlers are consequently disappointed upon arrival in the resettlement area. There is also confusion amongst the resettled population about who owns their houses and most resettlers are not aware of their rights.

The state exhibits ethnic and geopolitical motives in this resettlement. Mainly ethnic Tajiks are being moved to areas close to state borders, and sometimes to areas mainly inhabited by ethnic Uzbeks. Several representatives of international organizations in Tajikistan believe one aim of this resettlement is to "Tajikify" the borders in an attempt to increase border security. The Tajik government is resettling Tajik citizens in the frontier for reasons similar to that done by the Israeli government throughout the $20^{\text {th }}$ century, which are to strengthen sovereignty, to obtain territorial security, to stabilize frontier areas, and to maintain the boundaries of the state (Hasson and Gosenfeld 1980, 332).

The Soviet legacy is important in Tajikistan for state rejuvenation, but the continuance of Soviet practices is propagating citizens' Soviet-type expectations of the state. The state-directed cotton industry in Tajikistan is an example of this. 
Faced with devastated aluminum and hydroelectric plants at the end of the civil war, the Tajik government focused on the cotton trade to improve the economy. The central government sets annual quotas for each region and local administrators are reprimanded if they are not met, as during Soviet times. Resettlers in Tajikistan also have Soviet-era expectations of the state. They expect the state to provide housing, education, health care, employment, communication, water, electricity and land. These expectations are legitimized since according to the government resettlement resolutions, state agencies are responsible for providing this infrastructure. This legitimacy notwithstanding, the state is unable to meet citizens' expectations, leading to a complex situation where citizens take various approaches to gain access to such infrastructure.

Elements of the Soviet regime coexist with elements of a new independent Tajik state. Drinking untreated water has deteriorated the health of the population and a low income and infertile land has undermined their agricultural livelihoods. Many teachers have abandoned the profession because of the measly wage, leaving a shortage of qualified educators. The radical Islamic group Hizb ut-Tahrir al-Islami (The Party of Islamic Liberation) is reportedly scattering anti-government leaflets in the impoverished areas of the country and there is little attempt to address the economic sustainability of the cotton sector. Central Asian states are neither being built from scratch nor are they based entirely on Soviet structures. States are a mix of the "Soviet past as well as the international present" (Jones Luong 2004, 23).

Tajikistan is a "strong-weak" state. The state intervenes in the everyday 
life of citizens, but does not have the capacity to implement its policies and so society must fend for itself. However, the state is also able to shape the expectations of citizens and limit their access to scarce resources. Tajik society is also "strong-weak" as some resettlers are able to influence policy implementation by articulating their movement preferences, while others lack initiative and depend on a weak state to provide for them.

The origins of this project stem from my work at the IOM in Dushanbe, Tajikistan. The idea for this research came out of the results of a 2004 IOM preliminary study on internal displacement in Central Asia, which showed that internal displacement is not entirely voluntary in Tajikistan. As an IOM-funded project, I received permission from the IOM to use the results of the research for this study.

The strategy for this research was a survey approach. I conducted faceto-face in-depth interviews with 33 resettled migrants, 8 non-resettled migrants, 39 state officials and 33 international organizations representatives for a total of 116 interviews for the entire research project. The interview questions for each group are attached in Appendix 1, 2, 3 and 4 respectively. Interviews with resettled migrants, non-resettled migrants and international organizations occurred over the period August 2004 to November 2004. Interviews with state officials took place from August 2004 to March 2005. Resettled migrants were interviewed among eighteen resettlement areas and non-resettled migrants were interviewed in nine locations. 
On arrival in resettlement areas I first introduced myself at the municipal government office, presented my research to the local governor and requested permission to conduct interviews in the village. Although it was possible to approach state officials as an independent researcher for this study, access to these officials and resettlement areas would have been restricted. In many areas of Tajikistan, there were heightened security measures at the time of this research and as such, every foreigner was obligated to report their arrival and activities to the local governor. Being able to rely on the good reputation of the IOM, as well as the government's willingness to cooperate with an international organziation with a view of potential future assistance meant privileged access to state officials and resettlers.

I used the 'snowball' method of identifying interviewees. After receiving permission from the local governor to conduct interviews, I approached the director of the local school. I explained the project and asked whether they could recommend a resettled migrant to interview. Rather than asking state officials to introduce me to resettled migrants, since the presence of state officials may alter their answers, I chose to approach the director of the local school since he/she was usually aware of recently arrived families. After interviewing the first resettled migrant recommended by the school director, I asked if they could recommend another resettled migrant for me to interview. This method worked quite well since school directors were interested to fill my request and resettlers were not intimidated by the school director, as they might have been by state officials. 
There is a risk of producing a biased sample with this technique. Interviewees may recommend other subjects from a part of their community that may be similar to them in certain ways. In effect, the sample may exclude those who are not linked to the individual at the centre of the snowball. Although I aimed to interview equal numbers of men and women, the sample I collected over-represents men and the unemployed. I mainly conducted interviews during the afternoon and also during the cotton harvest, which means my sampling method may have excluded the employed. Also, although I interviewed many women resettlers, where men were interviewed their wives left the room and would not return despite my invitation.

One challenge that presented itself during the fieldwork for this study was that several resettlers would volunteer to be interviewed as a group. This raised questions of anonymity and confidentiality. A disadvantage of this interview technique is that the answers of one interviewee may influence those of another. On the other hand, the answers of one interviewee may spark the memory of another and in this way provide information that would otherwise be lost in an individual interview. Another advantage is that whereas if interviews were done individually, the interviewer may receive a range of answers to the same question and, although there may not be one right answer to the question, the researcher would interpret this in a certain way. In a group interview, the interviewees are able to discuss answers to the question amongst themselves. This method illuminates the multiple realities and perceptions that may exist and/or their consensus on which reality is 'correct'. While marginal or unpopular views may 
be suppressed in a group interview, the important factor here was that people remembered differently and remembered different things. Therefore the answers given by a group of people about the details of an event that occurred one, two or three years ago can provide more informative answers than if individuals were asked to recount the same event. As a result, group interviews were not refused if interviewees felt more comfortable in this format.

For this fieldwork, I travelled with a driver in a car marked with an IOM logo. As the location of this car at a particular house in the resettlement area may pose a risk to the owner of that house, the car and driver remained at the local school while I conducted interviews. In all cases, interviewees chose the location of the interview. Interviews with resettled migrants and non-resettled migrants for the most part occurred at their place of residence. Although it was assumed that they would choose a place that would not be a risk to their security, my emergence from that location may have posed a security risk to them due to my non-Tajik characteristics. Interviews with state officials and representatives of international organizations in every case took place at their office.

I conducted interviews in Russian or Tajik and the language was the choice of the respondent. A Tajik-Russian translator was present for those interviews conducted in Tajik. A total of twenty interviews were in Tajik and three different translators were used; two translators were IOM staff, while the third was the director of a non-governmental organization who had conducted training sessions on land rights in one resettlement area. For those interviewees who agreed, interviews were audio-recorded. Otherwise I wrote down interviewees' 
responses to my questions in my fieldwork notebook. A typist transcribed the audio interviews into electronic text documents. A fourth Tajik-Russian translator translated the Tajik parts of these interviews into Russian. The IOM official translator approved the oral skills of all potential translators.

The use of local translators can pose a confidentiality risk to interviewees. There is also a risk of biased responses and inaccuracies in translation. I briefed all translators and the transcriber on the resettlement schemes before meeting with interviewees and requested that they sign a confidentiality form. Despite these measures, inaccuracies may have resulted in translation since I do not speak Tajik and the translators were not experts on resettlement issues.

In addition to interviews, I conducted a media search to locate media coverage of this resettlement. I searched the Tajik daily newspapers Jumhuriat, Najot, Avesta, Charkhi Gardun and Asia-Plus and performed an online Internet search. I presented the preliminary findings of this research to members of international organizations and non-governmental organizations in Tajikistan on two occasions. The discussion that ensued was extremely insightful and helped me shape some of the arguments presented here. The material on which this report is based is thus drawn from diverse sources.

The quotations throughout this essay stem from recorded interviews, notes taken during interviews and observations recorded in my field notes. Pseudonyms are used in the place of individual names. Although those involved with resettlement in Tajikistan may recognize individuals quoted or portrayed here, I have made every effort to conceal their identity. 
In-depth interviews can provide rich descriptive and anecdotal data, which suggests patterns, variables and hypotheses for further study. Indeed the data collected here reveals much about how resettlers live, problems they encounter, their survival strategies and outlooks on their situation. The sample collected is not representative of the resettler population. The small data set fails to represent the totality of the resettler population's experience and does not allow a statistical analysis. I drew conclusions for this study by analyzing the text of each interview and identifying common themes for each of the main players in resettlement; resettlers, state officials and representatives of international organizations. Then, keeping in mind the definition of power, state capacity, state weakness and state strength used for this study, I developed conclusions about what the common themes illustrated about each of these aspects as they pertain to the players in resettlement.

The chapters are organized to highlight the interdependence of the players and the complexity of the resettlement situation in contemporary Tajikistan. Chapter 2 discusses the role of the state in resettlement. I show that the state is not a homogenous actor and is a mix of its Soviet past and international present. The state is able to manipulate the interests of international actors and resettlers in order to reach its own policy goals. Chapter 3 discusses the role of international actors in the Tajik governance structure and in resettlement. There is a significant international presence in Tajikistan. With different priorities and outlooks, there is more than one 'international community' in Tajikistan. Although international actors try to shape the state and resettlers, 
their effectiveness is questionable. Chapter 4 discusses the living conditions of resettlers, as well as the role of resettlers in resettlement and their interactions with state officials and international actors. I show that resettlers react to their situation differently and as such live in different conditions and share different realities. Resettlers are able to shape the state, just as the state is able to shape society. 


\section{CHAPTER 2}

\section{A FRAGMENTED ACTOR: THE STATE IN RESETTLEMENT:}

Located at a major intersection in the center of Dushanbe, and facing the Ministry of Foreign Affairs, is a monstrous statue of Ismoil Somoni, one of the Somonid dynasty's alleged greatest kings. The Somonid dynasty ruled over much of the Central Asian region for about 170 years in the ninth and tenth centuries. Costing over CAD $\$ 24$ million, this statue stands eleven metres tall under a golden arc and is guarded by two statues of tame lions on either side. Rediscovery of the Somonids, which reached symbolic culmination in 2000 with the erection of this statue, has formed the foundation of the new official history in Tajikistan where Ismoil Somoni is a cultural symbol of Tajik civilization (Torbakov 2001). To further instill Ismoil Somoni as a national symbol, the Tajik government introduced a new national currency called the Somoni and renamed Mount Communism as Mount Somoni.

As an independent, post-war state, Tajikistan is keen to promote itself as having a deep history and important presence in the world (Horsman 1999, 41). Charged with creating new institutions and building legitimacy after independence and the civil war, Tajik statesmen sought to build cohesion and serve new frameworks of entitlement and spatial sovereignty (Wennberg 2002, 408). Attaching a Somonid king to national items such as currency and geographical landmarks is to legitimize the Tajik nation-state and to build a general atmosphere of national glory and pride. In this pursuit, the state has also replaced Russian names of streets and cities with Tajik names, placed state flags 
and billboards with President Rakhmonov's words of wisdom along highways, as well as taken down statues of Lenin and replaced them with Tajik heroes ${ }^{6}$.

The state resettlement of households is also being done with the aim of nation building. In preparation for the $2700^{\text {th }}$ anniversary of the founding of the city of Kulyab, the central state apparatus has instructed the Kulyabi mayor to resettle 17 families currently residing on the site of the original city fortress (Dikayev 2005b). The state is resettling households not only for reasons of paying homage to sites of national historical interest and constructing the nation, however but also to improve border security and revive the cotton industry.

Through a discussion of these state motives for relocation of citizens, I will draw a picture of the complex situation that has resulted from resettlement. Old and new institutional forms, procedures and roles coexist in Tajikistan along with evidence of simultaneous high and low state capacity, resulting in a "strongweak", disconnected Tajik state that is in flux and far from a consolidated, definitive endpoint. This chapter will outline the actions of the Tajik state in resettlement and show the complex situation that has resulted from resettlement. I will start this discussion by explaining the resettlement scheme and the government motives for resettlement. After arguing that there are other underlying motives of the state for relocating citizens to the valleys, I will show the state is a fragmented actor exhibiting simultaneous low and high state capacity. The result is a "strong-weak" state that shifts between strong and weak over time and depending on the issue at hand.

\footnotetext{
${ }^{6}$ For example, in the city of Gharm, the statue of Lenin was replaced with a statue of Nusratulla Makhdum (1881-1938), the first chairman of the central executive committee of Tajikistan.
} 
Eight government resolutions enacted over the period 1999 to 2004 direct current resettlement schemes in Tajikistan and are the first indicator of the complexity of resettlement. According to these resolutions, state officials approach residents living in the relevant areas, explain the terms of resettlement and suggest that they take part in the relocation program. Both state agents and citizens must sign an agreement for this movement to take place. The government is responsible for transporting resettled households to the resettlement area, providing resettled households with financial assistance and land in the resettlement area, as well as preparing the resettlement area for their arrival. Resettlers are responsible for organizing their belongings and family for resettlement as well as for repaying a percentage of the financial assistance that the government provides to them in the resettlement area.

The eight resolutions dictate two types of movement of people within Tajikistan: movement from areas with a serious threat of natural disaster, or 'ecological migration'; and movement from areas with an inadequate amount of arable land, or 'voluntary migration', as termed by the Tajik state. People resettling from ecologically dangerous areas must take down their houses and relinquish their land to the local authorities. 'Ecological' resettlers are forbidden from returning to live in an ecologically dangerous area and should reassemble their houses in the resettlement area. 'Voluntary' migrants, on the other hand, may maintain their houses and land at their original place of residence after they migrate. 
The resolutions differ in more than outlining the difference between 'voluntary' and 'ecological migration'. While some resolutions are quite lengthy and call for general resettlement, others are succinct and call for resettlement from one specific district to another. Also, some resolutions specify the number of households to be resettled per district and the tasks of each state agency involved in resettlement, while others do not. Furthermore, the mere fact that the state passed eight resolutions over a five year period shows the commitment of the state to the resettlement of households as a state policy. The later resolutions do not address the inadequacies of the previous ones. Rather, each subsequent resolution outlines a new locality from which the government will relocate citizens. In all, a review of these resolutions governing state resettlement in Tajikistan reveals that resettlement is an involved and serious, but albeit confused effort of the contemporary Tajik state.

Resettlement areas are located in various regions of Tajikistan. Figures 2 through 4 show the geographical location of the sending and receiving areas, as well as the magnitude of resettlement. As these maps show, the government has mainly resettled people to the central and mountainous Varzob district, to the northern hilly Isfara district away from the border with Kyrgyzstan, to valleys in Zafarabad district near the Tajik-Uzbek border and to valleys in Beshkent district near the Tajik-Afghan border. The majority of resettlement areas are located within twenty kilometers of a state border, and most are along the Tajik-Afghan border. 


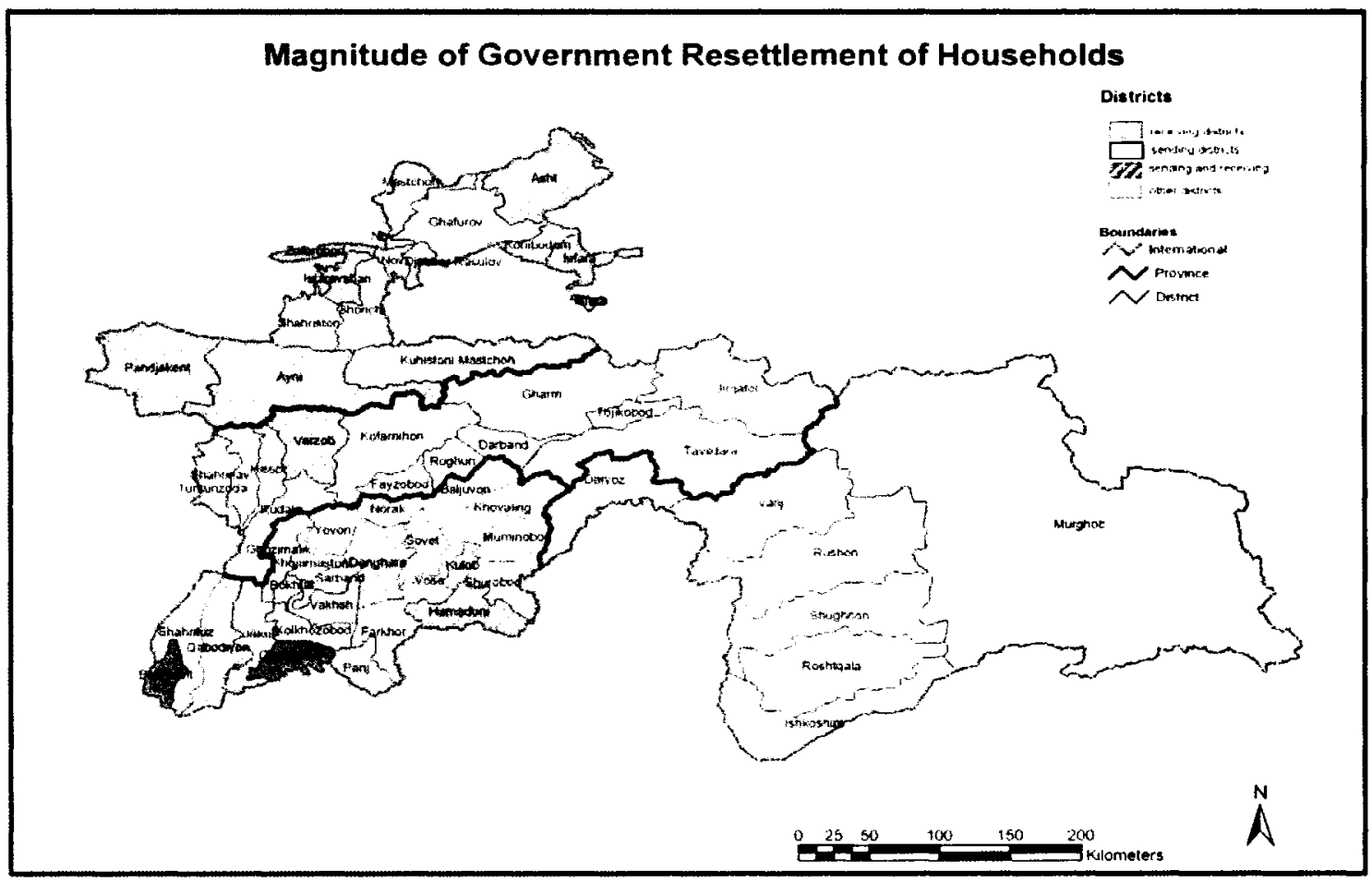

Figure 2. Geographical Distribution of Resettled Households:

\section{Sending and Receiving Districts}

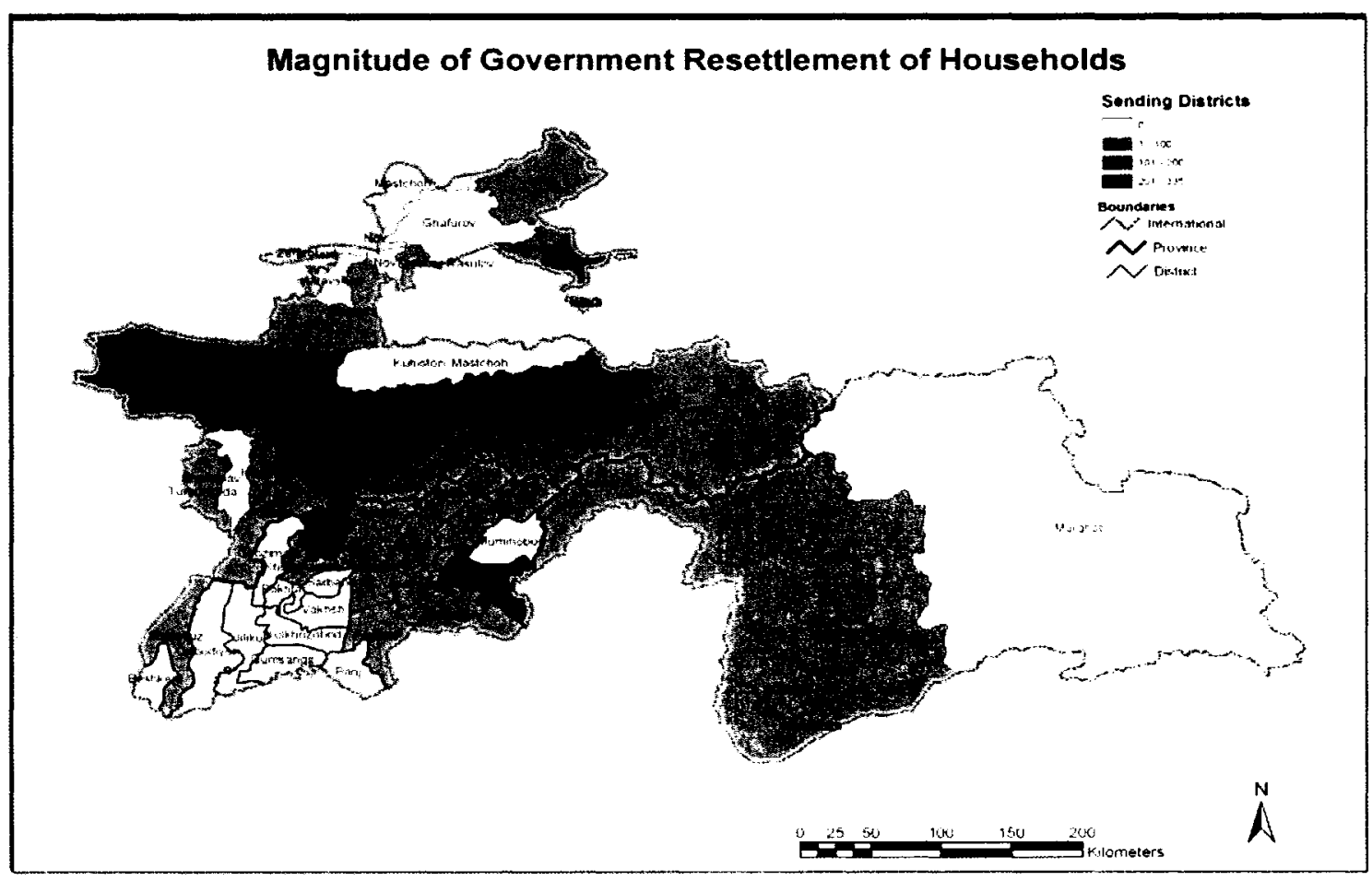

Figure 3. Magnitude of Resettlement: Sending Districts 


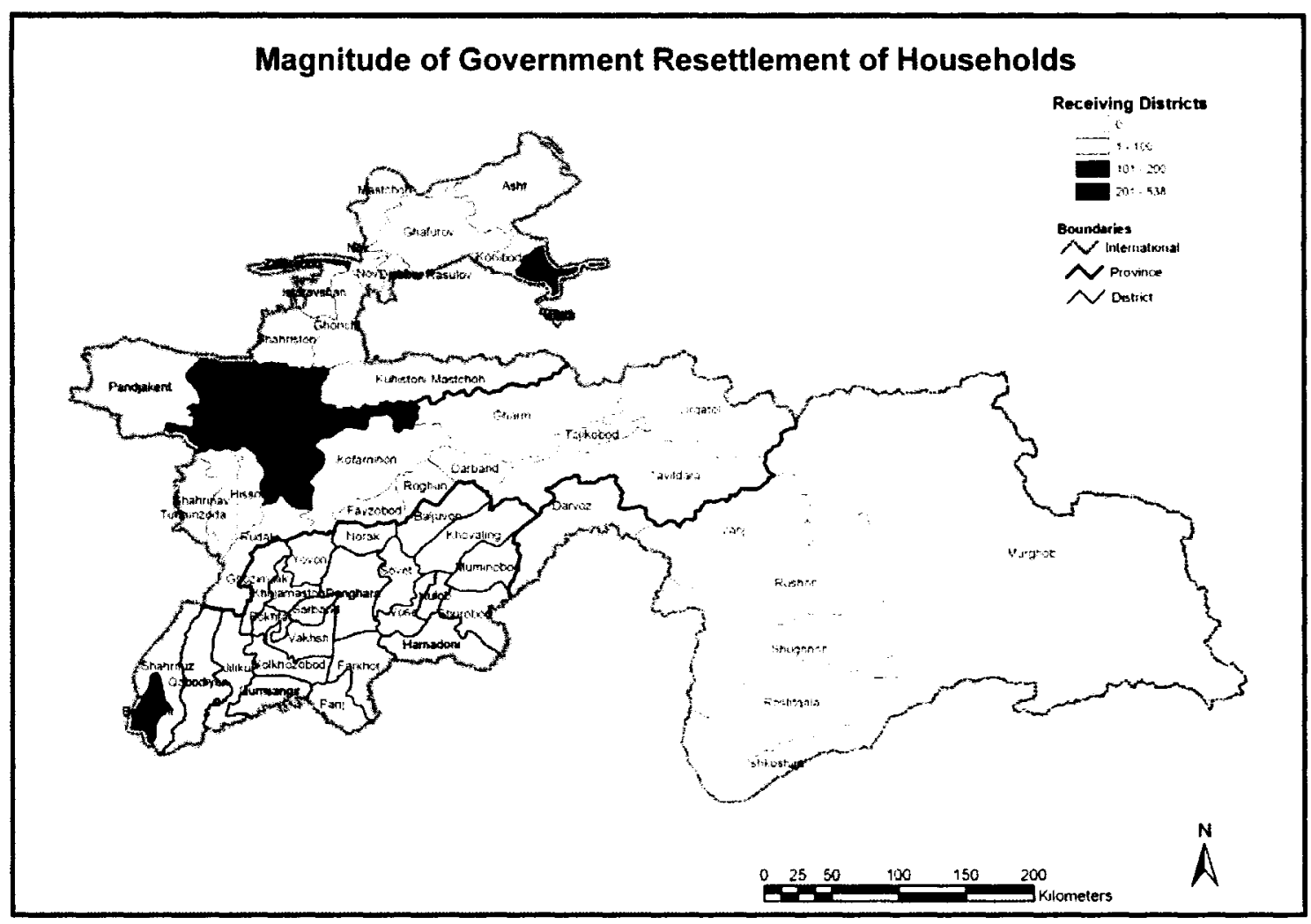

Figure 4. Magnitude of Resettlement: Receiving Districts

State officials explain that the Tajik government devised population resettlement schemes in an attempt to address the weak post-war economy, as well as to avoid the human and material loss associated with frequent natural disasters. This is in addition to the objectives listed in the resolutions governing resettlement, which are to develop the economy (Tajikistan 2001, Tajikistan 2004), develop land (ibid., Tajikistan 2001, Tajikistan 2003), increase employment (Tajikistan 2004) and decrease the poverty level of the population (ibid.). Due to its mountainous and extensively deforested landscape, much of Tajikistan suffers from annual floods, landslides, earthquakes, drought and avalanches. Natural disasters have been exacerbated by the fact that since independence in 1991, most residents have relied on burning wood and brush as 
a heating and cooking source since they live without electricity for much of the winter. This deforestation has rendered mountainside and riverbank support fragile (United Nations Office for the Coordination of Humanitarian Affairs 2002b). Since the Tajik state lacks a disaster management program, there are hundreds of victims of natural disasters every year. In the first nine months of 2005, 4654 residential buildings were affected by natural disasters, with 1429 of them destroyed completely, and 47 people left dead (Kondrashova 2005). Participants of a meeting held in October 2005 to discuss this situation considered resettlement of 838 families across the country to "the center" (ibid.). Indeed, resettlement is the manner in which the Tajik state deals with post-natural disaster situations. In such cases, the Ministry of Emergency is the first on the scene evacuating victims to a local, safe building and supplying assistance and materials to victims, after which State Migration Services becomes involved and organizes the permanent evacuation and resettlement of the victims to an area safe from natural disasters (Usmonov 2004).

According to state officials, the resettlement schemes are an attempt at disaster management before the fact, as well as an attempt to revive the devastated post-war economy. Economic conditions in Tajikistan deteriorated sharply in the first year after gaining independence in 1991. The subsequent civil war had a devastating effect on the civilian population and crippled the already weak economy. Four years of severe drought thereafter caused further damage and hardship. State officials viewed resettlement as an opportunity for a better life for people from impoverished mountain communities (Khairuddinov and 
Abdullaev 2004; Latifov 2004). Recognizing this ecological and economic reality, the Tajik government put forward a resettlement policy for disaster management and economic revival.

Interviews with state officials uncovered one additional aim of resettlement: to contain radical Islamic activity. One state official divulged that in addition to the reasons listed in the resolutions, the state was also aiming to change peoples' "religious mentality" through resettlement. He explained that the government is moving people from mountainous areas, where there is a "narrow way of life", and educating them in places where people are more "cultured" in order to contain Islamic fundamentalism (Vokhobov 2005). The general trend in Central Asia since the Tashkent bombings of 1999 and the events of 11 September 2001, has been to suppress domestic Islamic activity. In addition to arresting alleged supporters and members of the radical Islamist movement Hizb ut-Tahrir since 2000, the Tajik government clamped down on unregistered mosques in 2002, then in 2004 jailed the deputy chairman of the Islamic Renaissance Party, and in 2005 banned Islamic headscarves in secular schools (ICG 2003, i). Although some of these actions seem more an attempt to root out political opposition, others are to prevent the growth of religious extremism and present Tajikistan as a secular state (ibid., 14). Given these recent measures taken by the Tajik state, it is plausible that the state may also use resettlement to contain radical religious activity.

However, my examination of resettlement shows that although the containment of Islamic activity is one underlying motive of resettlement, it is not 
the main goal of relocation. The state planned to resettle the most number of households from the northwestern districts of Penjikent, Varzob and Aini, and not from the districts which are generally regarded as more religiously conservative and home to members of the Islamic Renaissance Party, central Garm district and southwestern Kurgan Tyube region (Horsman 1999, 37). The only reference to religion in interviews was in popular expressions such as "only god knows" or "it's up to god". The lack of reference to Islamic practice in interviews may imply that interviewees were reluctant to discuss such practices with the interviewer, the state is not actually resettling its target group or perhaps even that general religious extremism is absent. While some people in Tajikistan strictly follow Islamic rules and principles, others abide by them only on major holidays or for life-cycle ceremonies such as marriages, births, circumcisions and funerals (Akcali 2003, 418; Glenn 1999, 130). Although the Islamic Renaissance Party became a leading player in the United Opposition during the civil war, support for political Islam declined sharply after the end of the civil war. As explained by a 2003 International Crisis Group report,

for much of the population in Central Asia, Islam is not the central factor in their lives. Secularism has gone a long way in undermining religious norms, and the struggle to earn a living while battling with corrupt officials, closed borders and oppressive business environments looms largest (ICG 10 July 2003, ii).

The resettlement plans and interviews only weakly support the suggestion that the state is resettling citizens to stifle radical Islamist activity.

In addition to the state-declared resettlement motives of disaster management and rejuvenation of the domestic economy, there are two underlying state objectives of these resettlement programs: to strengthen 
national border security and to rejuvenate the cotton industry. The Tajik government aims to strengthen national border security through resettlement in several ways, including stabilizing border areas, ensuring spatial control over unstable territory and contested boundaries, and asserting spatial congruency of the Tajik nation-state. Similarly, by providing a labour force in cotton-growing areas, the state aims to rejuvenate the industry, but it also aims to make a considerable profit. The discussion will now turn to these two underlying motives of resettlement.

Foreseeing the eventual withdrawal of Russian troops from the TajikAfghan border and recognizing the importance of border communities in securing border areas, the Tajik state opted to resettle citizens in sparsely populated border areas to secure its borders. Members of the international community in Tajikistan, including the Russian border guards, have been concerned since the end of the civil war that the withdrawal of the Russian border guard service would render the Tajik-Afghan border less secure and porous to the illicit movement of people and goods, particularly narcotics (European Union 2005b; British Broadcasting Corporation 2005c). The Tajik government had the same concerns and acted by installing stationary civilians in border communities. Similar to the state resettlement of households conducted in Israel throughout the $20^{\text {th }}$ century, with a surplus of potential settlers and limited qualified soldiery, Tajikistan aims to stabilize frontier areas by household resettlement rather than through the massive expense of massing troops at the frontier (Hasson and Gosenfeld 1980, 320). One state official alluded to the fact that the Tajik state must devise its own 
methods of securing border areas when, in discussing the evolution of the resettlement programs, he stated, "Russia is not our state, it cannot guarantee the safety of our people" (Pulotov 2004). The Director for the Department of Regulation of Migration Processes and International Relations explained that entrants who bypass border checkpoints when entering a country usually choose uninhabited areas over populated areas when designing their route of entry (Vokhobov 2004). By this logic, inhabited border areas deter unofficial entry into the country. Therefore in resettling citizens to border areas, the state aims to supplement weak Tajik military force, curb illegal border crossings and in effect, improve border security.

Although resettlement under the resolutions to border areas began in 2000 , most telling is that a few months following the agreement with Russia for partial troop withdrawal in October 2004, the Tajik parliament approved a new five-year plan for resettlement of citizens to Pyanzh, a town located directly on the border with Afghanistan and only a few kilometres from a border checkpoint which was controlled by the Russian border forces. This resettlement site is also approximately fifteen kilometres from Nizhniy Pyanzh, to where people were resettled in 2004 and where a Tajik-Afghan bridge will be completed in 2007 . In addition to bringing citizens closer to potential economic opportunities that may arise as a result of the bridge, the resettlement strategy also populates a border area, rendering the state less vulnerable to entry by those who choose to bypass the border checkpoint or the future bridge. The risk is that these people could become conduits for illegal cross-border activity. However, international 
organizations recognize this risk and currently have several projects aiming to improve the living standards of border communities to alleviate this risk.

International actors are also bulking up Tajikistan's border guards at the frontier, which enables the Tajik state to focus its border security efforts on resettlement. After the fall of the Soviet Union, the events of 11 September 2001 , and the withdrawal of the Russian border forces, the policing of the TajikAfghan border has become a priority for many states in the international community. An effectively managed Tajik-Afghan border implies the containment of drug trafficking flows as well as the containment of people belonging to radical Islamist groups arriving from Afghanistan, all of which are priorities of Russia, the United States and the European Union, to name a few. Russian Defense Minister Sergei Ivanov admitted in October 2005 that the main threats to Russia's security come from Central Asia and especially from Afghanistan, with the main concern being the financing of terrorism through drug trafficking (RIA Novosti 2005b). International bilateral donors, mainly the European Union and United States, have been providing millions of dollars to train border guard officials, equip border checkpoints and implement measures to improve border security in Central Asia for several years. Though, drug interdiction has failed as evidenced by an increase in narcotics volumes being trafficked across the borders of the Tajik state since 2001 .

Tajik state officials also appealed to international donors to assist with resettlement of households, but most donors refused for reasons which will be elaborated on in Chapter 3. Realizing that the majority of international 
organizations refused to fund resettlement, but continue to generously fund border guard training and other border-related projects, the Tajik state opted to focus state funds on resettlement rather than on border capacity, and supplement Tajik border forces with a civilian population. It is this understanding of the priorities of international donors, as well as the receipt of international funds, which allows the Tajik state to allocate funding for and address its own priorities, in this case strengthening border security by installing civilians at the border.

In addition to populating border areas as a complement to military force, the Tajik government is resettling people to legitimize the borders of the state in an atmosphere of regional border disputes. Despite general agreement to use Soviet boundaries, negotiations between Central Asian state officials over where to demarcate the borders have often been contentious and as a result, the borders in the region have still to achieve their final status (Akcali 2003, 412; European Union 2002). This is often the case in post-colonial situations as political geographer J.V. Prescott notes, "[t]he re-establishment of these boundaries by the independent successors to the colonial states often causes friction and gives rise to territorial or positional boundary disputes" (Prescott 1987, 163). Although Kazakhstan and Turkmenistan agreed on the delimitation and demarcation of their common border in 2003, in 2005, longstanding border disputes were still unresolved between Kazakhstan and Uzbekistan, Turkmenistan and Uzbekistan, Kyrgyzstan and Uzbekistan, as well as Kyrgyzstan and Tajikistan (United Nations Office for the Coordination of 
Humanitarian Affairs 2005a; Akcali 2003, 411). In this climate of contested boundaries, state resettlement of households is a tactic that most Central Asian states are pursuing to control present and future border placement (Bosc 2004). While Turkmenistan uses forced resettlement to punish political opponents, assimilate ethnic minorities, curb cross-border smuggling of commodities, and to improve socioeconomic conditions by moving people to newly cultivated land, Uzbekistan has forcibly moved people away from the border to safeguard those living on the Uzbek-Tajik border affected by the risk of natural disasters, as well as incursions of the Islamic Movement of Uzbekistan (IMU) (Global IDP Project 2005a; ibid. 2005b). In Uzbekistan, mainly ethnic Tajiks were forcibly moved from the mountainous border region on the Uzbek-Tajik border in Surkhandaria province in southern Uzbekistan to a desert area 250 kilometres away, which is reminiscent of similar practices in Soviet times. With the Tajik population removed from the Uzbek side of Tajik-Uzbek border, President Rakhmonov is unable to lay future claims to this land or contest this border. Just as Uzbekistan is moving ethnic Tajiks away from the Tajik-Uzbek border, Tajikistan is moving ethnic Tajiks towards the Tajik-Uzbek border to legitimize the area as part of the Tajik nation-state.

Poor relations with Uzbekistan have also motivated the Tajik state to legitimate its borders through resettlement. The shared border between Tajikistan and Uzbekistan has been a major point of tension between the two states, as well as the precise site symbolizing these hostile relations. Although there has been cultural tension between Uzbekistan and Tajikistan with Tajikistan 
claiming that Uzbekistan undeservedly received the cultural centers Bukhara and Samarkand, and Uzbekistan claiming Tajiks are simply Uzbeks who have forgotten their mother tongue, relations between Tajikistan and Uzbekistan soured even further during Tajikistan's civil war and worsened following IMU incursions from Tajikistan into Uzbekistan in 1999. After these incursions Uzbekistan enforced a rigorous visa regime for Tajik citizens, installed land mines in its border regions, expelled residents from border areas, unilaterally demarcated certain border territories and regularly cut off energy supplies to Tajikistan (Bohr 2004, 495). As of October 2005 the Uzbeks had begun demining this border, but relations are still "frosty" between the two powers with trust and political will lacking on both sides (Azizmamadova 2005). In a climate of poor relations with Uzbekistan as well as fearing future Uzbek claims to land in southwestern Tajikistan where there is a mainly Uzbek population, the Tajik state is placing an ethnic Tajik population in border areas where there is a Tajik minority to ensure current and future spatial control over these potentially contested boundaries.

Power dynamics are salient at state frontiers and Tajik borders are no exception. State border regimes may be thought of as the ultimate exercise of power. Power there

...is a set of actions on possible actions; it incites, it induces, it seduces, it makes easier or more difficult; it releases or contrives, makes more probable or less; in the extreme, it constrains or forbids absolutely, but it is always a way of acting upon one or more acting subjects by virtue of their acting or being capable of action. A set of actions upon other actions... (Faubion 1994, 341).

Military force is the most visible symbol of power at state borders denoted by watchtowers, fences, checkpoints, surveillance equipment and border guards. 
Although such visible symbols of power remain intact at Tajik borders because the Russian border guards left their equipment behind after their withdrawal, Tajik border guard capacity is nonetheless low and so the image of power at Tajik borders is more symbolic than real. Despite this low capacity, border guard regimes, as well as the border communities located beyond them, signal 'other' to those located on the opposite side and constrain their movement across the border. The border also restricts mobility through visa regimes, limiting citizens' ability to cross the border and even enter the border area in some cases near the Tajik-Afghan border. Infested with land mines, the border also serves as a place of secrecy and fear, legitimated through a discourse of security (Berdahl 1999, 16). The exercise of institutional state power at borders produces this reality.

In addition to establishing resettlement areas for pragmatic geopolitical considerations, the Tajik state is also establishing border resettlement areas to assert the legitimacy of the Tajik nation-state. Research Fellow in Central Asian Studies Annette Bohr argues that all Central Asian states can be characterized as nationalizing regimes, aspiring to become the states of and for a particular core nation (Bohr 2004, 495). In her view these are more than attempts to strengthen sovereignty: the aim is to make the state and the nation "spatially congruent" (ibid.). This is indeed the case in Tajikistan, where the government is using resettlement schemes to achieve territorial congruency between nation and state. The state chooses the sending and receiving districts and in this way is ensuring the ethnic Tajik settlements coincide with current state borders. The bulk of resettlers are moved from areas of high ethnic Tajik population density to 
unpopulated areas or areas where there exists a Tajik minority living alongside another ethnic group majority. As pointed out by two representatives of international organizations in Dushanbe, only ethnic Tajiks could be moved since ethnic Uzbek or Kyrgyz populations are not present in the areas people moved from. However, the main point is that the state chose to resettle people mainly to areas with a low ethnic Tajik population. Resettling ethnic Tajiks to border areas positions the nation at the border and legitimates the Tajik state. As such, the Tajik nation-state is being constructed from the center outward and settlements along the Tajik-Afghan, Tajik-Uzbek and Tajik-Kyrgyz borders tie the periphery to the center and work towards establishing territorial congruency of the nation and state.

The ethnic dimension of this resettlement is most salient in Beshkent district. This area is located in southwestern Tajikistan less than 20 kilometres from both the Tajik-Uzbek and Tajik-Afghan borders. On arrival, resettlers encountered a mainly ethnic Uzbek population and learned the single language of instruction in schools was Uzbek (Saidov 2004, Beshkent 2 Group 2 2004). Although schools where Tajik is the language of instruction were later established in some resettlement areas, two resettlement area schools still teach only in Uzbek (Chashma Group 2004, Saidov 2004). This is undermining the resettlement objective of "Tajikifying" border areas since children are educated in a language other than Tajik. When asked why resettlers are being educated in Uzbek language, state officials responded there was a lack of Tajik language teachers in Beshkent district resettlement areas. This reveals poor state 
coordination since resettlers are offered employment according to their profession in the resettlement areas, but the state was unable to resettle the number of Tajik language teachers needed. Resettlement to this area went forward despite the fact that in 1999, government experts deemed the valley unfit for habitation (ICG 2005, 32; Mamadshoev 2002b). With such land conditions, the state could not have moved a mainly Tajik population there for land development or economic revival, as stated in the government resolutions. Although the area is a valley and apparently safe from natural disasters, more likely is that the state moved ethnic Tajiks there to make the state borders correspond to ethnic Tajik settlements by "Tajikifying" an ethnic Uzbek populated area. However, this was done in an uncoordinated manner revealing the Tajik state as a set of isolated and disconnected state actors.

Resettlers and representatives of international organizations agreed resettlement is being done to "Tajikify" border areas. One resettler in the TajikAfghan border settlement of Navruz informed, "[w]e were brought here to make Tajikistan a more Tajik place...It was a decree from the President. We were told that it was our duty to come here" (Chorshanbieva 2004). Similarly, resettlers from eastern Badakhshan province arrived in Beshkent in March 2002 "to make this corner of the Homeland flourish" (Abdullo and Akobir 2002). Most members of the international community in Tajikistan recognized this ethnic aspect of resettlement and, as mentioned earlier, refused to respond to government appeals for assistance in resettlement. In interviews, the majority of representatives of international organizations who were aware of the 
resettlement programs believed the motives to resettle households were several: economic development, land development and to "buffer the borders" with an ethnic Tajik population (Bosc 2004, Abel 2004, Hall 2004). They explained that the borders with Afghanistan, Uzbekistan and Kyrgyzstan are vulnerable since they are home to ethnic groups other than Tajiks and so the Tajik state seeks to 'buffer' them by placing ethic Tajiks there. Curious though, is that the state is moving ethnic Tajiks away from the border with Kyrgyzstan. This is not evidence of "Tajikifying" the borders, but the opposite. People are likely being moved away from this border because this district contains the highest population density in the country, but a lack of available land (Pulotov 2004). Despite this outward resettlement, an ethnic Tajik population is maintained at the border.

After improving state security, the second underlying objective of the state resettlement schemes is to increase cotton revenues. Under the planned relocation programs, the government has mainly resettled people to cottongrowing lowlands, where the cotton sector is often the only source of income. This is to provide a labour force in sparsely populated areas with potential for growing cotton (Khairuddinov and Abdullaev 2004). Southern Khatlon province is the heart of the cotton industry and produces sixty per cent of all cotton in Tajikistan, followed by Sugd at thirty per cent and Direct Rule District at ten per cent (ICG 2005, 6). The civil war was especially violent in Khatlon province and devastated much of the cotton-growing infrastructure there (Horsman 1999, 38). The 1999 drought also significantly reduced cotton yields. The state devised 
planned resettlement programs in an effort to rejuvenate this industry in Khatlon with new recruits and ultimately, to improve the national economy.

Unable to find employment in their profession, many resettlers are diverted to work in the cotton industry. Prior to resettlement, state officials informed potential resettlers that they would be employed according to their profession in the resettlement area, but the state did not extend concrete employment offers or orders. Those without a profession would be offered work in the cotton fields. While a handful of resettlers work as teachers, policemen, tractor drivers or state agents, the majority of resettlers in these cotton-growing areas failed to find employment according to their profession on arrival. With a lack of other income alternatives in the resettlement areas, these resettlers turned to working on the cotton farms. This occurred not because of purposeful deception, but rather because there was a lack of coordination of information between the sending and receiving areas. Receiving areas failed to inform sending areas of the number of professionals needed, while the sending areas chose resettlers according to their placement on the list, not according to their profession. Therefore often the type of professionals sent to certain resettlement areas conflicted with the employment needs of the resettlement area revealing poor state coordination. For example, many musicians and artists were sent from eastern Badakhshan province to various villages in Beshkent district. With only a school, a medical centre, houses and cotton farms in the resettlement villages in this valley, resettlers could not find employment in their profession, besides playing music at local weddings. As the income earned at weddings is 
not enough to sustain a family, these musicians and artists venture to work in the cotton fields. This uncoordinated employment-by-profession policy is ultimately providing a labour force for the cotton industry since many resettlers are unable to find work in their profession in the resettlement area and turn to the cotton fields as a source of income.

Such diversion has indeed increased cotton production in the majority of resettlement areas in Khatlon province from 31000 tons to 57000 tons for the resettlement period 2000 to 2003 (Tajikistan 2004, 20). To be sure, the expansion of the cotton labour force as a result of resettlement is not the only factor responsible for this increase; however, state officials acknowledge resettlement is a significant factor contributing to this overall cotton production increase (Vokhobov 2005). This may cease to be the case in the future, as resettlers, tired of working in the cotton fields without pay, prefer to not work at all, which was confirmed in interviews with resettlers (Nazirov 2005; Beshkent 2 Group 2 2004; Beshkent 2 Group 1 2004; Saidov 2004).

The motive for resettlement to these cotton-growing areas may also be coming from international actors. One futures company enjoys an unchallenged monopoly on credit, inputs and purchasing in Kabodiyon, Shaartuz, Beshkent, Kumsangir, Kolkhozobod, Jilikul and Pyanzh districts, all except two of which are resettlement area districts (ICG 2005, 8). The owner of this particular company has familial ties to President Rakhmonov and as a result could have been pushing for an increased labour force in these areas, though this information 
could not be confirmed (ibid. 2004). However, there is more evidence that shows the state is resettling people to rejuvenate the cotton industry.

Lack of water and widespread saline soil also divert the labour force in resettlement areas to work in the cotton fields. The agricultural sector consumes eighty-four per cent of all water used in Tajikistan, but the United Nations Development Programme estimates that only half of this water reaches the crops, the rest being lost to evaporation and inefficiencies in water transport infrastructure (United Nations Development Program 2003, 18). Ironically, in some places these infrastructure shortcomings and poor administration mean the land receives too much water. As it becomes saturated, the water table rises, carrying minerals to the surface. The land becomes swampy, and the water gradually evaporates, leaving a crust of salt behind. High levels of salt hinder plant absorption of water. Salinization puts a further strain on water use since farmers attempt to flush out their fields by applying even more water (ICG 2004, 34). Although most resettlers did receive private plots on resettlement, most plots are saline and located up to ten kilometres from their place of residence (Beshkent 2 Group 2 2004, Beshkent 2 Group 1 2004, Saidov 2004, Beshkent 1 2004). Lacking irrigation water for private use and accessibility to inputs such as fertilizer to improve the quality of the land, due to financial constraints and distance from district centers, many resettlers are unable to earn an income from fruit, vegetable or wheat growing (Chashma Group 2004, Shakhbur Group 2004, Sadulloev 2004, Chorshanbieva 2004, Selobod Group 2004). This information is corroborated by a 2004 Oxfam report, which states: "Only 5 out of 145 resettled 
families [in Beshkent 2] were able to cultivate lands" (Oxfam 2004). However, two groups of resettlers reported that they were able to grow food on their land (Muroteppa Group 2004; Karadum Group 2004). Most resettlers are unable to use their plot of land to feed their families, and with an absence of other infrastructure such as the service industry or small businesses in resettlement villages, the lack of water for household gardens and the low quality of the land plots they are given pushes people into employment in the cotton industry.

Additional evidence showing that an underlying objective of resettlement is to rejuvenate the cotton industry in Tajikistan is that two resettlement areas were designed specifically for the revival of the cotton industry in Beshkent district. Under an inter-regional agreement, the government resettled cotton specialists to Sultanobod and Muroteppa in the Beshkent Valley. All of these specialists work in cotton "by the order of the President" (Muroteppa Group 2004). President Rakhmonov visited these resettlers before their departure and announced that they were exempt from paying taxes for three years on the condition that they worked in cotton for that time period. Some resettlers in other areas also reported that they received this same offer. Although exact numbers were not available from the Tajik State Statistics Committee, this is evidence that the state is willing to forfeit tax revenue to potentially receive increased revenue from cotton. With cotton revenue totaling CAD $\$ 160$ million in 2004 , and tax revenue likely totaling much less since workers receive CAD $\$ 0.02$ for each kilogram of cotton they pick, it is not such a generous offer of the state to waive taxes. However, this exemption shows that the Tajik state understands what conditions 
motivate the citizenry to take the decision preferred by the state and that the state exercises the institutional power to induce them to make that decision. A personal visit and proposition to work and be exempt from taxes by the President himself is hardly an offer to be turned down in Tajikistan where the bulk of the population lives in poverty, distanced in status and location from the President. Although these workers stated they resettled for reasons other than this exemption from paying taxes, they told that it was nevertheless still an incentive to move (Muroteppa 2004). Over the course of one year, and with the help of equipment donated by their home district, these workers turned the swampy land they were given into productive cotton fields. This example shows how the President himself uses his "statist capital" to sway people into resettlement and work in the cotton sector (Bourdieu 1999, 57). Presidents have considerable authority over the citizenry, as do government officials, simply by virtue of holding the position through which one wields the power of the state. By understanding the desires of cotton labours, being able to make them a tempting offer and putting the difference in status between him and cotton labourers into operation, President Rakhmonov achieved the state goal of reviving the cotton industry through resettlement.

The state is heavily involved in cotton production and individual state officials personally gain from the industry, another motive for resettling citizens to cotton-growing areas. An ICG report states that "Despite some formal liberalization, the industry is still run by the state, for the state-or more accurately for certain key players close to the state apparatus, and powerful 
political players dominate the industry" (ICG 2005, 6). The Ministry of the Economy sets cotton production quotas for all cotton-growing districts that vary little from Soviet-style cotton production plans. These quotas are backed by state control of land use and local state agents in cotton-growing areas have an incentive to force fulfillment of these quotas (ibid.). These state agents are significant players in the industry closely linked with ginning companies and stand to make considerable profits from the harvest. District administrators often work "hand-in-glove" with so-called futures companies, forcing farmers to grow cotton and in some cases the administrator of a district or province will also have a controlling interest in the local cotton ginning plant (ibid., 7; United Nations Development Programme 2003, 38). In order to meet their quotas, local state agents put their office work aside during the harvest and pressure community members to assist with the cotton harvest ${ }^{7}$. They round up and ship school and university students to the cotton fields to pick cotton during the harvest without remuneration (International Organization for Migration 2005, 56). Local state administrators also pressure minibus drivers into transporting cotton workers to the fields free of charge. Those who refuse to assist with the harvest are penalized. For example, during winter 2004, the government cut the electricity supply for resettlers in the northern village of Selobod when they did not agree to prepare the fields for the spring cotton planting (ICG 2005, 26). The CAD\$915 000 spent on resettlement is justified since it secures a cotton labour force and in

\footnotetext{
${ }^{7}$ A portion of the field work for this project took place during the cotton harvest season. It proved especially difficult during that time to locate state officials for interviews since they were in the cotton fields directing the harvest.
} 
turn, significant revenue for the state and state officials. This shows the Tajik state seeks to maximize wealth, as do individual state officials.

Interviews revealed a fragmented Tajik state consisting of disconnected government officials with a Soviet memory working in the present. State officials have varying knowledge of resettlement policy and conditions in resettlement areas. Through a characterization of the disjointed Tajik state I will show that the Tajik state has multiple centers of authority and shifts between elements of Soviet legacy and new institutions which coexist, as well as between high and low state capacity. Despite evidence of low capacity, the Tajik state can use state structures and manipulate the interests of citizens and international actors in order to reach its own goals, revealing a paradoxical "strong-weak" state.

Tajik state officials have carried Soviet practices over to the independent Tajik state. Planned resettlement programs figured into Soviet internal migration policy and had the goal of boosting the cotton industry in Central Asia. One of the main migration policies in Central Asia during Soviet times was 'resettlement from the mountains to the plain', which was initiated in 1925 and lasted until 1940 in the Tajik Soviet republic. Professor at Stavropol State University in Russia, Pavel Polian explains that an excess of peasant population and high unemployment in mountainous regions, coupled with the need to bring huge reserves of unused lands into agricultural production dictated the logic of this organized resettlement in Central Asia. This migration occurred within regional boundaries and was aimed at rendering the country's economy self-sufficient in terms of cotton production and other crops. For the period 1925-1940, the 
regime resettled 48,000 households within Tajikistan, but approximately twentyfive per cent of these households could not bear the hardships of relocation and moved away from the resettlement area (Polian 2004, 67). Timur Nazarov, representative of the non-governmental organization Youth EcoCenter in Dushanbe, and Tadjiniso Nosirova, representative of the Ministry of Environmental Protection in Tajikistan, term this resettlement "tragic" for resettlers, citing the lack of state funds for resettlement and shortage of arable land as reasons for the general failure of these resettlement programs (Nazarov and Nosirova n.d.).

Failure notwithstanding, post-Soviet Tajikistan continues to implement such resettlement programs today. In interviews for this research state officials acknowledged the failure of Soviet resettlement policies in Tajikistan and admitted that many people who were resettled during Soviet times returned to live at their original place of residence on their own initiative after Gorbachev's 1989 resolution permitting freedom of movement. These state officials continued that resettlement under the Soviet Union failed because people were forcibly moved. The Director of the Department of Ecological and Voluntary Resettlement contends that since people move "voluntarily" under the current resettlement programs, the Tajik state is not repeating a failed Soviet policy, but rather "giving people a better life" (Latifov 2004 ). However, people's lives are not always better under the current resettlement programs, nor is resettlement entirely voluntary, showing a discrepancy between state officials' thoughts and the reality. This is another example of how Tajik state officials remain wedded to 
the Soviet way of doing things (Merry 2004, 286). Social theorist Mark Haugaard argues:

In a long established political system procedures become so taken for granted that political actors, by and large, would not consider questioning these structures and institutions. The procedures have become, so to speak, 'the way we do things here'. When practices are practical consciousness in this way, conflict over structure is substantially less likely than when procedures are newly established and hence more discursive consciousness (Haugaard 2002, 315).

Although the political system has changed in Tajikistan, actions have not. Procedures are predictable because they are the ones used during the previous regime. Since resettlement was the way to supply a cotton labour force during Soviet times, faced with the same need today this same approach is used by state officials in independent Tajikistan.

The nature of resettlement in Tajikistan is not 'voluntary' or 'forced,' but rather 'induced voluntary'. Nazarov and Nosirova write that current resettlement in Tajikistan is similar to that introduced in the 1930s, but it has important differences: "it is carried out on a voluntary basis" (Nazarov and Nosirova n.d.). Although these authors do not define the term "voluntary" in their article, such a categorization is inaccurate and fails to grasp the complexity of resettlement. For the purposes of this research, voluntary resettlement was defined as "resettlement to another area proceeding from one's own choice, unconstrained by interference, without legal obligation and with an awareness of the nature and consequences of one's actions". This definition was drawn from the definitions of voluntary repatriation and voluntary return in the 2004 International Organization for Migration Glossary on Migration. Using this definition, the "voluntary" nature of the resettlement programs in Tajikistan is questionable. As will be detailed in 
Chapter 4, despite the fact that resettlers of the 'voluntary' resettlement program made the choice to resettle themselves, unconstrained from interference and without legal obligation, very few resettlers were aware of the actual consequences of resettling.

Since this resettlement was not entirely voluntary a more accurate description is required. Indeed, few migrants are wholly voluntary or wholly forced as much migration involves some kind of compulsion and choice. Therefore it is more useful to consider the nature of migration along a spectrum, where most migration fits somewhere between the extremes of voluntary and forced, rather than at the extremes, and contains elements of both voluntary and forced migration. One migration determination model captures this spectrum by defining four major types of migration: voluntary, induced-voluntary, involuntary and compulsory-voluntary (Gebre 2002, 270). Induced voluntary migration occurs when people leave their place of residence to resettle elsewhere due to deliberate acts of inducement by outside agencies. Migrants have decisionmaking power, but many of the facts on which their decisions are based are analyzed and provided by state agencies. This type of migration best categorizes the resettlement under study here.

This migration is further coloured by elements of agency, deception and coercion. Although not officially permitted under the resolutions, in practice some resettlers exercised their option to both remain at and return to their original place of residence. However, such acts of agency were not always the case. Several state officials responded in interviews that they would convince such 
families to resettle by repeating that it is "forbidden" to remain in areas with a threat of natural disaster and asking them to think of the future of their children (Olimov 2004; Latifov 2004). Twenty-three Kulyabi families from Hamadoni state farm stated they were "incited" to move to Beshkent (Abdullo and Akobir 2002), while other resettlers reported that state officials confiscated their passports in the resettlement area, preventing their departure (Rushanova 2004, Global Partners 2004b). Discussions with international actors on the issue of departure from resettlement areas revealed the suspicion that state officials fear that an exodus would have a negative impact on their careers, since it could be seen as an admission that a social experiment instituted by President Rakhmonov has failed, though state officials did not admit this during interviews (Khairuddinov and Abdullaev 2004). In another case, the state coerced 75 families that survived a flood into resettling over 400 kilometres from their original residence by rejecting their request for new land near the disaster area and offering them financial and material assistance only in the resettlement area.

State officials also employed deception to induce people to resettle and this was most salient in their descriptions of the living conditions in resettlement areas. Although some state officials were truthful with resettlers about housing conditions, others gave false information. Some Tajik state officials deceived resettlers by describing good living conditions in the resettlement area, when these conditions did not exist or resettlers did not have access to them. In Kulyab city, state officials showed potential resettlers a video of a nice cabin surrounded by lush land and told them that they could expect to live in such 
conditions on arrival. However, after being guided to abandoned, looted homes badly in need of renovations on arrival, resettlers soon learned that the cabin and land in the video belonged to the local cotton farm manager (Sixty Years of Border Troops Group 2004). Likewise, state officials showed potential resettlers in Badakhshan province a film of an abandoned home and attractive facilities and told resettlers they would find such housing on arrival in Navruz (Mamadshoev 18 June 2002). A resettler explained:

\footnotetext{
Before moving here, we did not have any sort of impression about this place. Before moving we had not been here not even once. They showed small houses on the television, which were located along roads and said that there are available homes that need windows and doors. Then we arrived here and there were tents set up (Chorshanbieva 2004).
}

The resettlers passed these small homes on their way to their resettlement areas where tents were waiting for them (ibid.). Another family endured the journey to the resettlement area only to find that "their new home was a former cowshed, still full of manure and rotting hay, which they had to clear out themselves" (Mamadshoev 2002b; Prelics 2004). Most other resettlers arrived to find tents waiting for them. Resettlers from Sultanobod reported, "There is no housing here. They fooled us a little, they promised that there were houses available, but there were not" (Sultanobod Group 2004). Some resettlers were also told the land is fertile in resettlement areas. "[State officials] informed us that it is possible to receive several harvests per year" (Chashma Group 2004). Resettlers from Badakhshan believe state officials concealed the real state of affairs in Beshkent (Mamadshoev 2002b).

Although this concealment is plausible given the coerced and deceptive nature of resettlement, it is also plausible that state officials did not possess the 
accurate information themselves, revealing low state informational capacity. The state official heading the resettlement programs at State Migration Services in Dushanbe reported that as a result of financial difficulties the state is unable to provide a travel budget. He admitted, "I myself have not seen [the resettlement areas]...we have a poor state, I am unable to go" (Latifov 2004a). As a result, state officials are ill-informed of the true conditions in resettlement areas. On receiving such intriguing information from state officials about the conditions in resettlement areas, resettlers are apt to believe it since, in many cases, they and their family also lack the funds to travel to resettlement areas to view the conditions. With a lack of information resources providing such information, resettlers are dependent on information from state officials or acquaintances who have visited the area. Resettlers are therefore making important decisions based on unsubstantiated information as a result of the low financial capacity of the state. This low state financial capacity leads to misinformation and deception on the part of the state, as well as disappointment in the case of resettlers.

Despite this lack of coordination, state officials are able to exercise power over the citizenry. In providing both accurate and inaccurate information to potential resettlers, the state also shows itself as inconsistent and disconnected. At the same time, the state exhibited high capacity to gather, organize and transport resettlers to the resettlement area. This gives rise to what political scientist Kelly McMann terms a "strong-weak state" (McMann 2004, 285). In her analysis of the "civic sphere" in Kyrgyzstan, McMann explains that Kyrgyzstan is both a strong and weak state since it determines citizens' opportunities by 
limiting access to scarce resources on one hand, but it is unable to implement policies consistently on the other. This paradox is also the case in Tajikistan, where the state determines movement possibilities for the bulk of the population, yet is unable to implement resettlement policies in a consistent manner.

In addition to giving misinformation, state officials offered resettlers significant incentives, inducing them to resettle. State agents recruited potential resettlers in densely populated areas and areas with a threat of natural disaster. People living in such areas find appeal in these resettlement programs. Suffering from landslides and floods on an annual basis, in addition to living in mountainous areas with little garden space, people were attracted to resettlement since, according to state officials, they would be safe from natural disasters and able to grow more food for their family in the resettlement area (Latifov 2004; Vokhobov 2005). Other citizens were attracted to the possibility of new housing in the resettlement area. It is common that several generations of one family live in one house in Tajikistan and potential resettlers view the resettlement programs as an opportunity to relieve such congestion. Interviewees living in densely populated areas reported that prior to being introduced to the resettlement schemes they appealed to the local authorities for land, but the authorities refused their request. A State Migration Services official from the northern city of Isfara explained, "they were forced to move, because we have little land. If we gave all of our land for personal gardens, people would have nowhere to work" (Pulotov 2004). This reveals the land dilemma in Tajikistan. Arable land is scarce, yet agriculture is the foundation of both the 
national economy and employment. With a state policy for retaining land for state economic purposes, people have little choice other than to pile up in one household. Certainly the financial credit scheme adds additional incentive to resettle for citizens of Tajikistan. In a country where sixty-four per cent of the population lives in poverty, receiving $C A D \$ 560$ as financial credit for house construction, and grants of CAD $\$ 10$ for each head of household and CAD $\$ 6$ for each member of the family is quite appealing (World Bank 2005). Indeed, most resettlers interviewed for this research responded that receiving financial assistance and land in the resettlement area were the main stimulus for their decision to resettle. Indeed, "it was a lure too strong to resist for many families who struggled to eke out a living in [eastern Badakhshan province]" (Mamadshoev 2002b). With the infrastructural capacity to understand and offer solutions for the poor living conditions of its citizenry, the state induces the citizenry to take the decision preferred by the state. In this way it gains citizen involvement in policy implementation. Sociologist Steven Lukes argues that securing compliance by controlling the thoughts and desires of another person is a "supreme exercise of power" (Lukes 2002, 58). In Tajikistan the state controls land allocation as well as movement possibilities of the citizenry, which, having been the case since Soviet times, has created a need and desire for safe and additional housing on the part of the people there. In effect, over time the Tajik state has shaped the desires of the population with regard to housing and is now able to feed into these desires and act to meet its underlying objectives through 
resettlement policies. Although, as will be detailed later the Tajik state is unable to fully implement resettlement policy.

An examination of the financial credit scheme that the state offers as part of resettlement demonstrates the state's ability to exercise infrastructural power. The state provides financial assistance in order "to support the initiative and independence of ecological migrants and personal participation in their settling in [the resettlement area]" (Tajikistan 2000). Resettlers must pay back fifty per cent of the financial credit they received starting from the third year after resettlement until the fifth year. The remaining fifty per cent is paid at the expense of the state budget (ibid.). Some resettlers reported that financial credit is the only promise the state came through on. "Out of everything promised, they only gave us the credit, they are still promising everything else" (Beshkent 2 Group 2).

However, the state also exhibits low capacity in financial credit allocation. Most resettlers received a lower amount of credit than provided for in the resettlement policy documents, for example CAD $\$ 110,120,185$ and 520 . Some resettlers informed that state officials at their original place of residence promised to provide a monthly sum of CAD $\$ 10$ for five years to each household, but they have only received one installment of this grant (Chashma Group 2004; Beshkent 2 Group 2 2004). Many did not receive the one-time grant. State officials did not inform all resettlers about financial assistance and as a result, they did not attempt to claim it in the resettlement area. Other resettlers were told they were receiving an apartment instead of credit and since they did receive an apartment, they did not attempt to claim financial credit. The resolutions state 
that the Ministry of Finance allocates funds for this financial assistance to the state bank, which distributes the financial assistance to resettlers (Tajikistan 2000). State officials insisted in interviews that financial credit was distributed only through the bank, and resettlers received varying amounts because a certain amount was automatically deducted for those who agreed to have the state renovate their dwelling. However, on speaking with resettlers only a few agreed to such renovations, while others did renovations themselves. Therefore, this fails to explain the widespread inconsistent amounts of financial credit, which reveal low state capacity.

Financial assistance nurtures resettlers' dependence on the state. It places strict state control over citizens since resettlers must remain in the resettlement area until the financial assistance is paid back. With few employment prospects, it is unlikely that resettlers will be able to repay the credit according to schedule. In interviews state officials also gave different responses to the question of the procedure in the case a resettler is unable to repay their portion of the financial credit, revealing further inconsistency, disconnect and unpreparedness of the state for such a reality. This debt leaves citizens under the control of the state and demonstrates how the state is able to exercise infrastructural power despite low state capacity.

State officials have different understandings of the rules of resettlement, revealing low institutional capacity for implementing policy and that the state is not a unitary actor in Tajikistan. State officials responded differently to my question in interviews about whether resettled households can return to their 
original place of residence. The Minister of State Migration Services answered that resettlers can return, but he does not see the logic in doing so since the conditions in resettlement areas are better (Bobaev 2004). Some answered that resettlers can leave anytime and stated, "Nobody is forcing them to live there" (Zuribekov 2004) and, "If they want to leave, they will leave. It is their own will" (Avazlieva 2004). Others replied that resettlers can leave if they provide state officials with the name of a guarantor (Pulotov 2004; Olimov 2004). Yet another answer was that resettlers cannot leave during the first five years after resettlement (Barotov 2004). This is actually similar to the condition on return listed in the government resolutions, which states that those who receive financial credit from the government after resettling are registered and prohibited from moving away from the resettlement area for five years, or until the credit is repaid. Some state officials maintained that resettlers could leave before repaying their debt. These contradictory statements on a major crux of the resettlement scheme, the right to return, testify to the low capacity of state cadres and demonstrate that the Tajik state is a disconnected set of actors with various understandings of state policy. With inconsistent understandings of the program among state officials, resettlers gain the capacity to determine their own movement, as will be detailed in Chapter 4. Although some resettlers do not move from resettlement areas because of their dependence on the cotton industry for income, they nonetheless still have the capacity to move. The state does not have effective control over the movements of citizens: it only has a monopoly on the authority to restrict movement. 
In practice, the Tajik state does not have the capacity to enforce the rules of resettlement, however they are understood. Although the independent Tajik state inherited intelligence and policing institutions from its Soviet counterpart, it cannot control the movement of resettlers and as such, the state objectives of resettlement are being undermined. Two local representatives of State Migration Services stated that they conduct monthly checks on resettled families to confirm their residence and determine their place of employment. However, with few income opportunities in resettlement areas, people are leaving to seek employment elsewhere without notifying the local authorities. Those who have the means to seek work elsewhere leave the resettlement areas in this pursuit. Many resettlers have left for Dushanbe and even Russia and Kazakhstan, as will be described in more detail in Chapter 4 . Others have left for their former place of residence, including forty households originally from Badakhshan province and five households from Kulyab city. The authorities lack the institutional capacity to track these citizens outside of the resettlement area. This ineffective tracking system reveals a weak state that is unable to implement the five-year residence policy. This low institutional capacity directly undermines the resettlement program since resettlers can leave resettlement areas without state permission. The result is a decreased cotton workforce and fewer people to safeguard the border areas.

The state aims to play the role of provider for and director of its citizens as during Soviet times, but it fails to live up to this role. State agencies are responsible for ensuring that all infrastructure is ready in the resettlement area 
before the resettled population arrives. This includes water, electricity, communication lines, transport routes, schools and medical centres. State officials added in interviews that the state must supply the population with employment, as during Soviet times:

In the village Chorkukh, there are 26000 residents, but there is not any kind of industry, business, there is only one farm that has 200 hectares of plowed land and about 400 hectares of orchards. People have to work somewhere. They have to be supplied with work...We are forced to resettle them, residents of these villages in these districts (Pulotov 2004).

In addition, state officials report that they "help with food and all the necessities that they need, that they demand, these resettlers... what they need, food, money, everything that is necessary, we [give this assistance]" (ibid.). One woman informed that state officials told her only to take enough food for three days to the resettlement area since the state would provide resettlers with food on arrival. However, the state did not provide food on arrival and eventually the woman sold her gold jewellery in order to buy bread and vegetables (Sixty Years of Border Troops 2004). This was also the case in other resettlement areas. Another resettler describes, "on arrival here, we suffered a lot since we had practically nothing to eat" (Beshkent 2 Group 2 2004). The state fails to play the old, mythical role of provider for the citizenry.

State officials rely on old, Soviet-era information to choose resettlement areas, and therefore fail to realize the actual conditions in resettlement areas. State officials revealed in interviews that resettlement areas were chosen based on the presence of abandoned homes and vacant land (Umarov 2005, Pulotov 2004). Others disclosed the use of old information, saying, "[w]e resettled to Beshkent because...at one time they gave a good harvest of cotton" (ibid.) and 
"[t]here had been an excellent state farm there during Soviet times, which produced high quality cotton and everyone lived "really well" (Bobaev 2004). Still another state official answered, "there are not a lot of people there, there is a lot of land, the land there is good, the living conditions are good and the area won first place for tomatoes in harvest competitions under the Soviet Union" (Umarov 2005).

The fact is that this Soviet-era information fails to accurately describe the area today. The five-year civil war had a disastrous toll on basic infrastructure and this coupled with natural disasters has left 80,000 hectares of land salinized and 30,000 hectares water-logged (ICG 2004, 34). The land in resettlement areas in the northern Asht district and southern Beshkent district is particularly heavily salinized (ibid.). As discussed earlier, many resettlers are having difficulty growing food on the land they receive on resettlement and in some cases this has forced resettlers to beg for food from fellow villagers. State officials often fail to realize this reality. A state official in the northern city of Isfara reported, "In Beshkent...there is good land there...people who resettled there received a good harvest of melons, onions, wheat, they had a good cotton harvest in Beshkent...There is land. There is water" (Pulotov 2004). The same state official reported that resettlers in the northern town of Shurab live "with all of the living conditions, with all of the conveniences. We extended a water-pipe system for them to provide them with water and now they live in good conditions" (ibid.). However a representative of the international organization Schools Online in Isfara reported that the land is not fertile in Shurab, people live in poverty, 
there is a lack of water and it is not safe to drink. Indeed, interviews with resettlers in Shurab confirmed these details (Shurab 1 2004, Shurab 22004 , Shurab 3 2004).

State officials make and defend decisions based on old, Soviet-era information and this coupled with the domination of cotton in the agricultural and economic sector, means that resettlers face low food security in resettlement areas. The use of Soviet data for present policy shows that the resettlement plan is not based on the current reality and does not have the objectives of decreasing poverty of the population and developing land as stated in the resolutions governing resettlement.

Questions about soil quality in resettlement areas also exposed inconsistent understandings of the resettlement program among state officials. As mentioned earlier, State Migration Services carried out an assessment of Beshkent district in 1999 and determined it was unsustainable for mass migration movements. In 2001, different employees at State Migration Services conducted another similar assessment and concluded the region was sustainable (ICG $2005,27)$. Curiously, none of the state officials reported that Beshkent district was chosen as a resettlement area because of this favourable assessment. The Minister for Labour Migration and International Relations responded that state agents at the State Land Committee took a soil analysis of land in different potential resettlement areas. They chose the most fertile land for resettlement so that families could feed themselves and work. Although he could not provide a copy of the results of this analysis, he continued that the soil analysis for Navruz 
was of low quality and that is why the resettlement there is not very successful (Vokhobov 2005). The state agent in charge of resettlement at State Migration Services in Dushanbe also reported that a soil test is performed before sending people to a given area, but could not share the results of these tests (Latifov 2005). However, the deputy of the State Land Committee responded that this information was incorrect. Land analyses are not done in Tajikistan since land can be neither bought nor sold. According to him this means that there is no need to know whether the land is fertile and a commission of representatives from various state agencies choose resettlement areas based on a general survey of the area (Umarov 2005). Although state officials may have given answers that they believe international actors like to hear, such inconsistent responses expose the fragmented agencies that make up the Tajik state that collaborate on occasion, but which for the most part work in isolation with different information.

State officials exhibit different attitudes towards resettlers. Some state officials are assisting resettlers in their new area. In addition to sending three tractors and seeds with resettlers to the resettlement area, one state official in a sending area proposed, "whatever problems they bring up, we try to solve" (Pulotov 2004). Other state officials have ordered the repair of water motors, provision of food supplies, medical centres and telephone lines after resettlement (Rakhimdzhanova 2004). President Rakhmonov visited the village Dashti Zhon to view a new school and Prime Minister Akil Akilov personally visited Beshkent district to evaluate the implementation of resettlement, after which he ordered the 
construction of water pipelines and electricity lines (ibid.). The head of the Department of Social Protection of the Population Bobokhon Makhmadov also visited Beshkent district and hosted an open meeting with resettlers (Mamadshoev 2002a). He decided issues of land allocation, passport renewal and provision of farming machinery (ibid.).

Other state officials interviewed for this study expressed a hostile attitude towards resettlers. The general opinion amongst these agents is that resettlers expect too much from the state. "They can't expect everything on a silver platter" (Vokhobov 2005). Another official singles out resettlers from eastern Badakhshan and concludes, "They do not want to work. They have never-ending problems and they only talk about their problems. I cannot find a common language with them" (Avazlieva 2004). Indeed, the first language of these resettlers is Pamiri, but they do speak Tajik. They moved from a mountainous location with a cool climate to a flat, desert area with extreme temperatures and high winds, and their answers in interviews demonstrate that they had the most difficulty adapting to the climate and landscape in the resettlement area. When explaining that these resettlers waited for the government to fix their roofs when a strong wind tore their roof panels off, this same state official commented, "These are their houses, they should want to fix them. Should the government brush the mosquitoes away for them? Why don't they live and do something with their life?" (ibid.). One representative of the Aga Khan Foundation took a similar view stating, "Resettlers cannot sit there with empty hands. They have to work for themselves, doing chickens or lambs...Saying "this is so difficult" all the time 
affects their children. They cannot have everything in five years" (Abdullaev 2004).

The main issue here is that the state is unable to follow through on its promises. It is attempting to play the old Soviet role of provider, but due to poor administration and infrastructure shortcomings it is unable to play this part successfully. As such it is unrealistic for resettlers to expect the state to provide for them today, despite what the state says or promises. That said, I believe the state is at fault here. Most resettlers find the state responsible for their situation, not themselves. By promising good living conditions in resettlement areas and then not providing them, the state is creating a disillusioned resettlement community, the repercussions of which will be elaborated on in Chapter 4 .

Tajikistan is a dynamic post-Communist state shifting between elements of Soviet legacy and new institutions which coexist. Tajikistan is a mix of the Soviet past and the globalized, international present. It also presents itself as a sovereign state by coining money and building national heroes, as well as by managing its own borders. The Tajik state has multiple centers of state authority operating at the central, district and local level. Actors at the lower levels are as important as the central ones in determining the shape of the state and its ability to implement policies and achieve its goals. Resettlement has produced a confused situation, with multiple sets of rules, and uninformed and disconnected state officials unable to implement resettlement policy according the plan due to low state capacity. The state and state officials exhibit both low and high capacity. They are able to exercise infrastructural power, and still have the 
capacity to use state structures to achieve goals. However, the state is unable to consistently and fully implement policies, revealing low capacity. The state is able to manipulate the interests of citizens and international actors in order to reach its own goals through infrastructural and coercive capabilities, revealing a paradoxical "strong-weak" state. 


\section{CHAPTER 3}

\section{IMPORTING THEIR INFLUENCE: INTERNATIONAL ACTORS IN TAJIKISTAN}

Traveling from Tajikistan's capital city, Dushanbe, to the south-central city of Kulyab, the rough dirt road with many potholes suddenly transforms into a smooth paved road. Roads in Tajikistan are generally poor and so smooth roads are immediately noticeable. In response to my comment on the sleek road, my driver replied, "the Italians built it." Roads elsewhere in Tajikistan are due to improve as the Asian Development Bank pledged CAD\$ 2 million in 2005 to repair the rural road system, a necessity for this landlocked country, highly dependent on its road system (United Nations Office of Coordination of Humanitarian Affairs 2005b). Most infrastructure that is in good condition in Tajikistan has been repaired or built with international donor money. Japanese donors funded the repair and construction of elementary schools, the French military repaired the Dushanbe airport landing strip and the United States government is currently funding the construction of a bridge linking Tajikistan with Afghanistan. There are numerous other instances where international donors have funded projects that achieve less visible results, such as the organization of disaster management training seminars, micro-credit schemes and elementary school breakfast programs.

This chapter will first chronicle current international interest in Tajikistan and then discuss relations between international actors and the state, as well as relations between international actors and resettlers. I will show that international actors depend on the Tajik state to endorse their activities, while the Tajik state 
depends on international actors to compensate for low state capacity. Relations between the two groups reveal both overt and subtle forms of power. I will also demonstrate that the international community in Tajikistan is a fragmented actor by outlining the range of responses international organizations exhibit to the state policy of the resettlement of households, which are based on the mandate of their organization as well as their personal perceptions of the government motives behind resettlement. The result is various types of relations between international actors and state actors. Finally, I will outline the various types of relations between international actors and resettlers and show that these relations also uncover both overt and subtle forms of power.

International interest in Tajikistan grew after the events of 11 September 2001, as new security concerns in Central Asia emerged. Although international actors have been present in Tajikistan since the fall of the Soviet Union, the security and well-being of Tajikistan quickly became a priority of Russia, Europe and the United States after 11 September 2001 since, sharing a long border with Afghanistan, it was seen as the gatekeeper in preventing 'terrorist' elements from reaching their soil. However, this interest in Tajikistan is also due to Tajikistan's conduct at home and in the international arena. Tajikistan first made clear its refusal to support terrorist activity in early 2001 when it ousted those people allegedly involved in the Islamic Movement of Uzbekistan (IMU) ${ }^{8}$. Then after declaring its position as an ally in the American-led 'war on terror,' and making efforts to build a multilateral foreign policy, Tajikistan emerged as a "credible

\footnotetext{
${ }^{8}$ In 2005, the Tajik state continued to engage in operations against the $I M U$, Hizb ut-Tahrir and other groups it regards as security threats.
} 
player" in the international arena (United States Embassy in Tajikistan 2005). As a result of this stance and the new security concerns in the region, the number of international actors in Tajikistan especially grew after the events of 11 September 2001.

In order to meet the objectives of their security agenda, the states embroiled in the 'war on terror' increased donor aid to Tajikistan after 11 September 2001. In 2005, the United States government was the largest bilateral donor in Tajikistan, extending CAD $\$ 70$ million for all United States assistance programs in Tajikistan, with most of it slated for security and law enforcement programs ${ }^{9}$ (United States Agency for International Development 2005; United States News Service 2005). According to the United States Administration,

\begin{abstract}
United States assistance aims to enhance Tajikistan's territorial integrity and security; prevent the flow of narcotics, illicit weapons, and persons of concern; foster democratic and economic reforms; and address dire humanitarian needs...a stable, peaceful Tajikistan, secure within its own borders, will help prevent the spread of radical groups and terrorists, and increase the potential for development in the region (United States Library of Congress 2005).
\end{abstract}

The United States aims to support its own security agenda through assistance to Tajikistan as it explicitly states that assistance funds requested for the 2006 fiscal year will help Tajikistan "support U.S. security interests and objectives" (ibid.). The European Union also acknowledges that international security is one of its goals in providing assistance to Central Asian countries. In its strategy paper outlining its financial assistance program in Central Asia it states that

\footnotetext{
${ }^{9}$ This amount is small relative to United States government aid to Afghanistan in 2004 which was CAD 1 billion, and to Iraq, which was CAD $\$ 3.5$ billion (United States Embassy in the Philippines 2005).
} 
[i]t is clear that overcoming the challenges faced by the region is vital both for the countries themselves and for wider international peace and security...The EU has a strong interest in using all the means at its disposal to promote the peaceful political and economic development of the region (European Union 2002).

The ambassador of the Embassy of the United Kingdom in Tajikistan openly stated that the Embassy was established there due to regional security concerns (Ruz i Nav 2004). These states are involved with Tajikistan to meet their own security objectives.

This self-interested presence for the sake of security is an established practice. As political scientists David Lehrer and Anna Korhonen state in their study of post-communist aid negotiation,

[m]any have argued that development aid is structured and allocated so as to promote donor interests, that the West sets development agendas and guidelines for action, that donor discussions of recipient interests are rhetorical postscripts to decisions self-interestedly made ... (Lehrer and Korhonen 2004, 598).

An academic with the Institute for International Studies of Copenhagen and representatives of Danish Church Aid and the Danish Refugee Council relate this self-interest to security in their analysis of forgotten humanitarian crises. They conclude, "we are witnessing a new security agenda characterized by the increased use of humanitarian aid for the purpose of crisis management" (Olsen, et al. 2003, 122). Indeed, this is true of the case described above. The United States and the European Union are candidly using financial assistance to meet their own security interests in Tajikistan.

Russia is meeting its own security interests in Tajikistan through business investment and military installations. In announcing the new ambassador to Tajikistan in 2005, Russian President Vladimir Putin called Tajikistan a "priority partner", stressing the importance of bilateral military and technical cooperation 
(RIA Novosti 2005c). Although Russia has maintained its presence in Tajikistan since Soviet times, it began solidifying its security ties and geopolitical influence in the region after 11 September 2001 (Bohr 2004, 489). According to Russian Defense Minister Sergei Ivanov, the main threats to Russia's security come from Central Asia, and mainly from Afghanistan (RIA Novosti 2005b). Russia's military presence in Tajikistan helps Russia counter these security threats, as Tajikistan protects Russia's southern border from threats from Afghanistan due to its location in Central Asia. Most recently Russia secured this presence through investment. In agreeing to invest in the construction of two hydroelectric power plants and write off CAD $\$ 290$ million of Tajikistan's debt, Russia won unlimited use of Tajik military bases free of charge (Buszynski 2005, 559). Although Russian troops withdrew from the Tajik-Afghan border in 2005, this departure was countered by the installation of a Russian military base in Dushanbe and the Russian takeover of Tajikistan's space monitoring centre at Nurek (British Broadcasting Corporation 2005b). Commenting on the installation of the Russian military base, Martha Brill Olcott stated, "It's more about Russia benefiting from being able to expand its forces, rather than helping Tajikistan's current situation" (Salahi 2005). Regardless of whether Russia is helping Tajikistan's situation, security is the decisive factor in explaining the growth in Russian assistance and investment in Tajikistan since 2001. The case of Russia shows that in addition to increased donor assistance, the security agenda since 11 September 2001 is also characterized by increased investment and military presence in countries of interest. 
Such international interest bodes well for Tajikistan financially. One of the poorest republics during Soviet times, it emerged after the civil war in total economic ruin. Tajikistan has annual state revenues totaling CAD $\$ 360$ million, annual state expenditures totaling CAD $\$ 373$ million and a total external debt of CAD\$ 1.25 billion (United States Central Intelligence Agency 2004; United States Department of State 2005). The only former Soviet republic to fall into a prolonged civil war, Tajikistan is the Central Asian state most dependent on external economic and military support (Merry 2004, 296). The attention and financial assistance Tajikistan has garnered since the beginning of the 'war on terror' has been a "financial windfall", in addition to a boost in its geopolitical status (Bohr 2004, 490).

Having understood Tajikistan's strategic geographical importance to the international community, and its own dire economic situation, President Rakhmonov has expanded his appeals for assistance in areas unrelated to security. For example, in 2005 , he appealed for CAD $\$ 15$ billion to achieve the United Nations Millennium Development Goals, which include halving the number of poor and halting the spread of HIVIAIDS and malaria by 2015 (United Nations Office for the Coordination of Humanitarian Affairs 2005c). In his opening remarks at the 2003 United Nations-sponsored Fresh Water Forum, he stated that Tajikistan is not fully capable of maintaining, repairing and operating its water infrastructure, and he closed his speech with an appeal for financial support in this regard (Eurasia Net 2003). Rakhmonov's call was heard since in 2005, the World Bank allocated CAD\$ 15 million in non-repayable funding for an 
overhaul of the water system in Dushanbe and in Sugd province (Institute for War and Peace Reporting 2005b). As Erika Weinthal concluded in her study of international actors in the environmental sector in Central Asia, "post-Communist states may encourage international involvement to perform what are ostensibly state tasks because they are weak and poor" (Weinthal 2004, 251). Tajikistan is appealing to international actors to assist with state tasks because it is weak and poor, but it is also making such appeals because it understands the priorities of international actors. Therefore just as state actors understand the needs of the citizenry and in this way are able to influence their decision-making process, state actors also understand the priorities of the international community and in this way are able to gain increased financial assistance.

The Tajik state determines the presence and activities of international actors in Tajikistan, revealing elements of the power of the state. In 2005, the Tajik authorities enforced a policy by which all organizations funded by international donors communicate their activities, including meetings with Tajik activists, to the Ministry of Foreign Affairs. Also in 2005, the Ministry of Foreign Affairs failed to renew the temporary resident visas of several employees of the American organization National Democratic Institute, apparently linked with the "colour revolutions". Furthermore, perhaps his own response to regional action against the United States in 2005, President Rakhmonov stated that "there never was nor will there ever be" a United States military base in Tajikistan (Radio Free Europe/Radio Liberty 2005a). As vulnerable as it might be, and even though it grapples with the dual incentives, pressures and interventions of Russia and the 
United States, Tajikistan benefits from an augmentation in political status and exposure on cooperation with both the United States and Russia.

International organizations occupy a place in the governance structure in Tajikistan as a result of their non-profit and non-violent aims. Lacking the authority of law enforcement agencies and substantial economic resources of corporations, international organizations operate on a level different from states and transnational companies. Although Tajikistan may be under pressure from other states to incorporate international organizations into its governance structure, the credibility, respect and influence of international organizations is primarily founded on their non-material power resources. Perceived to act out of motives other than the accumulation of wealth, and since they pursue power politics by persuasion rather than coercion, international organizations are prescribed legitimacy and influence in governance structures as "knowledge brokers" (Holzscheiter 2005, 726). These actors bring modes of interaction as well as resources, and as a consequence, "multiple facets of power and loci of authority" (ibid., 724). Power lies not only with the Tajik state, but also with international actors in Tajikistan who have been incorporated into the governance structure.

International organizations exercise power through text and speech. In collaborating with state officials, international actors must find issues of common concern and connect via the token linguistic rules and social practices of the environment, all the while making their text and speech resonate with officials. International actors are in a favourable position to do this especially in situations 
of asymmetries of knowledge that provide these actors with the greatest inroads into decision making processes (Holzschleiter 2005, 743). International actors bring non-material resources to such discussions, including knowledge, expertise, information, contact and credibility. In this way, international organizations become forceful actors vis-à-vis states. Indeed, several representatives of international organizations that I interviewed for this study explained that in their experience, the framing of issues and sharing of prized information was extremely important in dialogues with government. An OSCE representative explains:

Silent diplomacy is sometimes the useful way. Shouting about human rights can be helpful, but sometimes one gets better results in other ways...We have an ongoing dialogue with the government on human rights, we are moving ahead with prison reform and on the death penalty - we have gotten results. If we maintain good relations with the government, its much easier for us to work...There is a climate of cooperation and non-confrontation, and it is working (ICG 2004, 16).

The placement of international organizations in Tajikistan's governance structure, and the fact that their power lies in linguistic creativity, or how they frame discussions with state officials, as well as in their resources, shows that in Tajikistan "political power is being repositioned, recontextualized and to a degree, transformed by the growing importance of other less territorially based power systems" (Held et al. 1999, 447). There is no monopoly on power as it is dispersed throughout structures, practices and players in Tajikistan.

Several international organization representatives interviewed in Tajikistan exposed their assumptions about the Tajik state in their responses to questions on resettlement. Some international actors argued they must intervene and rein in the Tajik government in its approach to resettlement. One representative 
stated, "[t]he international community needs to address this issue. The government is acting inappropriately and violating human rights. The offerings for the resettled migrants are unfair...It is an example of top-down authority, Soviet-style..." (Abel 2004). This representative judges the activities of the Tajik government based on western ideals of human rights and uses western claims to formulate her opinion, which is Eurocentric behaviour according to political scientists Caroline Thomas and Peter Wilkin.

[T] We West has built an image of itself as the disseminator of enlightenment, progress and civilization to the rest of the world...The a priori assumption is that the west strives to do good and occasionally errs...Eurocentrism is a term often used here to describe the assumption that western claims to knowledge are, a priori, the highest against which all others will be judged (Thomas and Wilkin 2004, 252).

Human rights concerns are certainly noble applied anywhere in the world. However, the concerns expressed by some representatives of international organizations are embedded with the assumptions that Soviet concepts should be replaced, and that the Tajik state needs to be directed. To be sure, the Tajik state summoned international actors to assist with this cause after independence. This invitation notwithstanding, some international actors view their role as teachers and enforcers rather than as advocates, and in making such assumptions they fail to benefit from lessons they may have learned from fusing ideas rather than imposing their own ideas.

International organizations present in Tajikistan have various mandates, interests and activities, which can cause friction between organizations. Tajikistan receives aid not only from bilateral donors such as the United States government and the EU, but also from multilateral and non-governmental donors. 
The Aga Khan is the largest non-state donor, though there are dozens of other non-governmental organizations operating in the country with headquarters abroad. The main multilateral donors are the World Bank, Asian Development Bank, United Nations, International Development Bank and the European Bank of Reconstruction and Development. There are other international nongovernmental organizations operating in the country, which are also dependent on donors themselves. As stated in the introduction, I interviewed thirty-five representatives of international organizations for this study in twenty-eight different organizations, including twenty international non-governmental organizations, seven multilateral organizations and one bilateral organization. These organizations are of different shapes and sizes with different annual budgets, mandates as well as target groups and scope of activities. Organizations with similar mandates can also be differentiated within the international community in Tajikistan. For example, the United Nations High Commissioner for Refugees (UNHCR) and the International Organization for Migration (IOM) both concentrate on migration management. Although these organizations cooperate, they conceptualize their place in the global migration management system differently and these differences in their perceptions can cause friction in inter-agency interaction. When activities are not clearly identified and communicated, overlap may occur leading one or both organizations to conclude the other is invading their traditional territory.

Given the differences between international organizations in Tajikistan, it is hardly surprising that the government resettlement policy resulted in a range of 
responses from the international community ${ }^{10}$. Divisions between organizations include their placement within or outside of the United Nations system, the country of origin of their donors and extent of experience in Tajikistan. Some organizations have been in Tajikistan since during the civil war, while others set up more recently. Since 1999, the Tajik government has appealed several times to international organizations located in Tajikistan to assist in the resettlement of households. Some organizations willingly provided aid, while others staunchly refused. Still others assisted and then later declined to provide aid.

This chapter will now focus on the divisions among international community representatives in Tajikistan. Through an outline of the various opinions on and approaches to resettlement, I will show that assistance to resettlers has been uncoordinated. In addition, representatives of international organizations work based on their personal perceptions of government actions and their own place in the Tajik governance structure.

Representatives were informed on resettlement to varying degrees, while others were completely unaware of the resettlement policy. Those organizations unaware of the policy ${ }^{11}$ were likely bypassed by the government in their appeal for assistance since their scope of activities did not encompass anything related to resettlement. Representatives of international organizations may also have

\footnotetext{
${ }^{10}$ The divisions within the international community in Tajikistan in terms of their approach to aid coordination came to light in 2001 when these organizations attempted to coordinate aid to Afghan refugees stranded on the Pyanzh islands between Afghanistan and Tajikistan. "There was significant disparity between the positions of the various humanitarian organizations on the issue of moving the displaced Afghans into Tajikistan" (Overland 2005, 139). This incident was after the civil war and some of the organizations present were under pressure to make themselves useful in the country in a post-war atmosphere, which may explain the difference in organization approaches.

${ }^{11}$ These organizations were Relief International, Mission East, ICRC, German Agro Action, Save the Children UK, Mercy Corps (Khujand affiliate) and MSDSP Khorog.
} 
been unaware because the representatives of these organizations arrived after 2003 when most appeals for assistance from the government were being delivered. Representatives of ten international organizations were informed on the government resettlement policy, but stood aside from providing assistance ${ }^{12}$. Although this group shares the approach to resettlement policy of not providing aid, their motivations vary. Some organizations did not provide aid despite being informed of the situation because their scope of activities does not permit this. For example, United Nations Office for the Coordination of Humanitarian Affairs (UNOCHA) is a neutral coordinating organization in times of natural disaster. Since resettlement by state policy did not occur after natural disasters, UNOCHA was unable to mobilize funding for the cause. In another case, the headquarters office of Save the Children USA instructed the director in Tajikistan against providing aid due to the possible ethnic angle of resettlement. A local affiliate of Shelter for Life in the northern town of Shaidon was also knowledgeable and involved on local examples of resettlement, but was dependent on orders from its Dushanbe office for aid provision.

Fourteen organizations opted to provide aid to resettlement areas, but with various motivations. The European Commission (EC) provided indirect assistance to resettlers by including two resettlement areas in the geographical scope of its call for project proposals for a poverty alleviation program in Khatlon province. The EC representative responded in an interview that they decided to

\footnotetext{
12 These organizations were Counterpart, International Federation of the Red Cross, Oxfam, Save the Children USA, Schools Online, United Nations Development Program, United Nations OC Humanitarian Assistance, Shelter for Life (Shaidon affiliate), World Health Organization and International Crisis Group.
} 
include these two resettlement areas in the call for proposals because of a government request to do so and after doing an assessment for themselves, they concluded the two resettlement areas were indeed in need of humanitarian assistance (Habart 2004). Some organizations provided assistance only in a certain resettlement area and only for a limited time. Mercy Corps installed water pumps in the northern resettlement area Somoniyon because of the need for potable water as identified by the prevalence of water-borne diseases and also because it was identified as a need by Isfara district government to resettle people there (Burniske 2004).

Several organizations chose not to render assistance in Beshkent valley due to seeming ethnic overtones of resettlement, but opted to provide aid elsewhere. Shelter for Life assisted resettlers in Navruz, but not in Beshkent, though they did not investigate the possible ethnic motives behind resettlement. Action Against Hunger was also hesitant about giving aid in Beshkent because of the suspected political motives behind resettlement, but provided aid nonetheless in five resettlement areas. These suspicions about the motives behind resettlement were not based on their own information, but information circulating in the international community. Other organizations were in general disagreement with the programs, but provided aid because the situation and entire population of the resettlement area, indigenous population included, fell into their scope of activities. For example, Global Partners Dushanbe provided aid because food security is tightest in the springtime and because "the situation seemed dire" (Gamble 2004). The Aga Khan Development Network also 
provided aid in the form of transportation to a natural water source free of charge.

The Aga Khan Foundation (AKF) has a memorandum of understanding with the government that both parties will support each other's activities. Although the text of this memorandum was unavailable for consultation during this research, the AKF directed aid at the Ismaili resettled population and did not include the indigenous population or other resettlers in the aid program. This raised concerns among members of the international community about possible conflict in resettlement areas, though this research did not uncover any such conflict.

Other organizations gave aid with conditions that resettlers and the government had to fulfill. In its 'food for work' program, the United Nations World Food Program (UNWFP) provided resettlers with food assistance in exchange for their help in building their house. However, this occurred only in two areas since it was carried out on the condition of a contribution from the local government. In other resettlement areas the government did not contribute for housing and so UNWFP provided only food aid in the form of seeds and flour in two resettlement areas.

Resettlers' need of assistance prompted other agencies such as the Central Asian Development Agency ${ }^{13}$ (CADA) and the Shaartuz office of the Organization for Security and Cooperation in Europe (OSCE) to provide aid. The Shaartuz OSCE office is located 20 kilometres from Beshkent valley and as such, was heavily involved in resettlement. Resettlers appealed to this office for

\footnotetext{
${ }^{13}$ CADA is a Christian humanitarian relief agency which provides food and material aid to those in need. It also has an English language center and an Internet resource center. It's goal is "the relief of suffering and improvement of the lives of the people of Central Asia, physically and spiritually."
} 
assistance and in this way the director of the office developed a rapport with resettlers. As resettlement and migration are not in the scope of OSCE activities, this organization could not launch a project in a resettlement area. However the director of this organization donated a refrigerator and Russian textbooks to resettlers. He also communicated the details of resettlement to representatives of other international organizations that could potentially assist resettlers.

Several representatives of international organizations chose to stand aside from assisting resettlement areas based on their perceptions of government motives. Although the European Commission Humanitarian Organization $(\mathrm{ECHO})$ has the capacity to assist any vulnerable population, the representative of this organization was skeptical of the government's capacity to carry out its resettlement policy. Having visited one resettlement area, she wondered whether the government had thought through the potential consequences of resettlement and believed that state capacity was a serious limiting factor in resettlement policy implementation. She wondered what the procedure was if people returned to their abandoned homes to find resettlers living there. She also wondered how the government believed they could fulfill their promises to resettlers. Her motivation for not providing aid seemed to lie more with her lack of confidence in the government, than with resettlement areas not meeting ECHO's criteria for project initiatives. The decision was also taken according to how the government was conducting itself in the case with Save the Children USA, whose headquarters instructed the director to abstain from assisting due to the possible ethnic factor and political overtones of resettlement (Save the 
Children USA 2004).

Three organizations categorically refused to assist in resettlement, also due to their perception of government motives behind resettlement. These organizations chose not to assist because of the political motives behind resettlement, though their suspicions were based on similar resettlement schemes in other Central Asian state and the apparent trend of resettling Tajiks to areas mainly inhabited by Uzbeks. None of the organizations had conducted a fact-finding mission to determine whether there was any truth to these political motives. This shows that some international organizations in Tajikistan make decisions to provide aid based solely on their perceptions of government activities. In the case of those organizations which abstained from providing aid, negative perceptions of government capacity and integrity set the pretext for aid provision.

International assistance to resettlers has been largely uncoordinated due to a mismatch of approaches to domestic aid provision. While some representatives argued for aiding the citizenry whenever required, others were extremely cautious about when and where they provided aid. Still others were both cautious and generous. An international agent in disagreement with providing aid explained her position thus:

The international community cannot and should not respond to the government requests for assistance. This will encourage the government to continue with such resettlements...(Abel 2004)

This is similar to her position in 2002 when she wrote: "Any assistance to resettled populations will be viewed as an enabling action which may absolve the government of its responsibility to provide assistance that has been promised" 
(Abel 2002). Similarly, another international actor responded, "[i]f the international community takes a united stance on this, the government will not be able to carry out its plan. They can't move people when no one is willing to fund it" (Gamble 2004). At an inter-agency meeting on resettlement in 2004, "All participants felt that the government had unnecessarily branded the relocations as an emergency situation, and that this should not be encouraged" (UNACU 13 May 2004).

These comments show that international actors believe they accurately gauge state capacity, that they have power over state policy and that aid provision is tantamount to policy implementation. These international actors assume that the state lacks the financial capacity to realize state policy on its own. They also assume that international assistance for a given state program is an endorsement of that program and that such endorsement necessarily leads the state to enact similar programs in the future. To be sure, aid provision is a powerful tool. Japan, one of the world's largest aid donors, used foreign aid in the 1990 s as a tool of foreign policy vis a vis recipient countries and imposed aid sanctions when issues at stake overrode the country's economic interests (Katada 2001, 55). However, it is important to note that despite the decision of these organizations not to provide aid, the Tajik government passed a resolution in 2005 for another resettlement program. This indicates that the Tajik government is intent on resettlement despite the opinions of international actors and its low capacity. 
International organizations also believe they have clout with the Tajik government. "It was decided [by $3 \mathrm{UN}$ agencies, $3 \mathrm{EU}$ agencies, 3 other agencies] that it would be appropriate to deliver a note of concern to the government, which should also indicate a willingness to support such issues in a more developmental fashion" (United Nations Office for the Coordination of Humanitarian Affairs 13 May 2004). The United Nations Office for the Coordination of Humanitarian Affairs agreed to prepare the draft of this letter for comments, but it was never sent. Since the person responsible for sending this letter had left Tajikistan at the time of this research, I was unable to determine why this letter never reached the government.

Some agencies were more concerned with changing the living conditions in resettlement areas than with changing government policy. In discussing the implications of aid provision, the representative of the Central Asian Development Agency explained his position thus:

[Resettlers] are barely surviving on the international assistance they are receiving. If international aid stops then only the migrants will suffer, this will not change the way the government thinks or prevent them from carrying out additional programs. The government will find ways of carrying out resettlement. The question is how can international organizations pull out without resettlers suffering? (White 2004)

The OSCE representative expressed a similar view: "international organizations have the possibility to do something, so they should do it" (Prelics 2004). For these international actors, helping those persons in need when possible is more important than trying to change government practices. This outlook results in a different approach to aid provision and ultimately fragments the international community in Tajikistan. 
International organizations also exhibit a lack of coordination of activities and information amongst each other, further exposing the fragmented international community. Although the representative of the OSCE did well to inform other organizations of the resettlement situation in Beshkent valley, in general, incorrect information about other organization's activities and misconceptions about the resettlement outcome circulated among international actors. Several representatives reported that certain other organizations had assisted in resettlement, while these other organizations stated that they had not assisted. One representative reported that interest was being charged on the financial credit that resettlers receive, though the responses of all state officials and resettlers fail to support this. In 2002, after the flood in Dasht, some organizations made an attempt at coordination and organized a meeting for several international organizations to discuss their approach to resettlement. Although this meeting brought seventeen agencies together, it excluded more agencies than it included. One conclusion written in the minutes of this meeting was, "[t]he international community agreed that assistance would not be given so as to prevent encouragement of such programs" (United Nations Office for the Coordination of Humanitarian Affairs 14 Aug. 2002). However, only certain members of the international community were at the meeting. Therefore "international community" here means one of many international communities in Tajikistan. Not everyone agreed that assistance would be withheld, only select agencies agreed to this. This lack of coordination is not particular to Tajikistan, as political economist Kent Buse writes that international agencies remain 
remarkably uncoordinated in many low and lower-middle income countries (Buse 1999, 219). International organizations in Tajikistan indeed exhibit low levels of coproduction and connectedness. The paucity of partnerships between international organizations in Tajikistan results from different approaches to humanitarian aid, as well as agency cliques.

International organizations are divided internally in their approach to resettlement, and this is most revealing in the case of the Aga Khan Foundation. While representatives of the organization in Dushanbe are critical of government incapacity to fulfill its promises to the resettlers, as well as the government disregard for options other than resettlement and the forced nature of resettlement of those from Dasht (Feerasta 2004; Husani 2004), one Aga Khan representative in Khorog is critical of the resettlers for expecting the government to fulfill its promises (Abdullaev 2004). This divergence of opinion is interesting, given the Aga Khan Foundation's special status in Tajikistan. As mentioned it has a memorandum of understanding with the government that both parties will support each other's activities. This is the only example of such agreed-upon cooperation in Tajikistan, revealing yet another division in the international community.

Another aspect of relations between the state and international actors is that the state takes advantage of international organizations. As mentioned in Chapter 2 , the health care charity MERLIN provided a shipment of medicine to a resettlement area through a local public prosecutor, which is standard procedure. On tracking the shipment, however, the organization found out that the medicine 
never reached the resettlement area. MERLIN representatives, and an OSCE representative who investigated the case, suspect that the local public prosecutor sold it to local pharmacies for profit (Prelics 2004). In addition, MERLIN received a letter from the state requesting assistance which used the date people were supposed to have arrived in resettlement area. However, when this agency visited the resettlement area, they found out that people had just moved one week earlier (Guillemot 2004). Other examples of such activity were not uncovered during this research, although it was unexplained how resettlers received financial aid in varying amounts. State officials take advantage of international aid for their own profit. This undermines both the activities of international organizations and state resettlement policy, as well as the relationship between the state and international organizations. The state deceives international organizations just as it deceives resettlers.

International organizations perceive themselves as a unique and fixed part of the governance structure in Tajikistan. In an Integrated Resettlement Assessment plan designed in 2002, the director of CARE outlined proposed tasks of the international community and government in resettlement. Based on the proposed agreement, the international community was to act as a policy developer, assistance provider and government monitor (CARE 2002). Although never enacted, this plan demonstrated the director's belief that the international community plays an integral role in policy implementation in Tajikistan, especially for holding the government accountable. In 2004, the United Nations Office for the Coordination of Humanitarian Affairs convened a meeting of nine agencies 
after the government requested that they organize emergency assistance for resettlement areas. At the meeting, these agencies "expressed concern that the international community had not been involved in the planning of the relocations at an earlier stage, and questioned the government's overall approach to the issue" (United Nations Office for the Coordination of Humanitarian Affairs 2004). They also agreed that they would like to be informed and involved in government plans for further relocations. At the same time, however, they criticized State Migration Services for approaching the international community for emergency assistance before approaching other government agencies (ibid.). Although representatives of international organizations perceive their work and resources as indispensable to implementing government policy in Tajikistan, they prefer to see the government exhaust its own resources before appealing to them for assistance.

The example of resettlement after the flood in Dasht, eastern Badakhshan also illuminates these relations between international actors and the Tajik state. In August 2002 a devastating flood occurred in a mountainous village in the eastern province of Badakhshan. Twenty-four people died and two hundred and fifty families were left homeless. During the flood, village residents ran in three different directions: further up the mountain, behind the flood and towards the road. With bridges collapsed and roads destroyed after the flood, victims were isolated in the areas they escaped to (Pirmatova 2004). The state took advantage of this displacement pattern in advocating resettlement. While flood victims were holding a memorial service for the deceased on the mountainside, 
President Rakhmonov arrived and held a meeting on the roadside to discuss and take a vote on relocation options available to the victims.

After stating there was limited land available for relocation in eastern Badakhshan province and that a risk of another natural disaster would be retained on reconstruction of Dasht, the only serious option given to victims was resettlement to southern Khatlon province, more than four hundred kilometres away (Global Partners 2004). According to a Global Partners representative who attended the meeting, the majority of flood victims were not at the meeting that decided their fate. Those that voted at the meeting were locals who were there out of curiosity, not because they were victims. This representative concluded that this was a "show meeting", attended by phony victims to help the state carry out its resettlement policy. While this conclusion could not be confirmed, it could also not be determined whether President Rakhmonov deliberately chose to exclude victims from the meeting by scheduling it to coincide with the memorial service. In any case, President Rakhmonov was able to shape the votes of those at the meeting, either by selecting who would take part in the vote or by using his status and authority in describing the options available to victims.

Through this meeting, President Rakhmonov also attempted to show to the international community that resettlement from Dasht was voluntary using a technique endorsed by international actors, a vote. However, due to the presence of an international actor at the meeting and his observations, the international community was not convinced of this. Though, international actors never outwardly criticized the government on this. This example shows that 
international actors act as observers and monitor the actions of the Tajik government, but carefully choose which issues to approach the government on.

Resettlement after the flood in Dasht shows relations between resettlers and international organizations are diverse. Several international agencies opted to abstain from assisting with resettlement from Dasht. Although they acknowledged the poor living conditions in resettlement areas, these actors were more concerned with sending a message to the government than with the living conditions of resettlers. Most of these agencies were willing to assist resettlers, but only if they could first hold the government accountable. The actions of the government were the main subject of discussion at the United Nations Office for the Coordination of Humanitarian Affairs meeting, not the situation of resettlers. The only action meeting participants decided to take was to write a letter of concern to the government, which was never delivered. This approach distanced these organizations from the resettlers, as well as from the situation in resettlement areas.

Relations between resettlers and the AKF show that the primary concern of some AKF representatives is to support the government, while for other AKF representatives it is to assist the Ismaili Muslim population in Tajikistan. As mentioned earlier, the AKF supports government programs and mainly works in eastern Badakhshan province. After the memorial service in Dasht, AKF representatives from the Khorog office visited those victims who found refuge in the mountains and told them that their neighbours below on the roadside had agreed to move to Khatlon province during the meeting with the President. AKF 
representatives explained that they could not help keep flood victims in Badakhshan province, as victims requested. They continued that they "would not meddle in government plans," (Pirmatova 2004) revealing their intimate partnership with the local government. These representatives then coerced these victims into resettling by saying that many flood victims had already agreed to resettle and that "there will not be any kind of assistance here. How will you live?" (Pirmatova 2004). AKF representatives used the ability they had to travel to the different areas where victims were located and convince them to take the decision preferred by the state. Having lost all of their belongings, animals and savings, and with no prospects for receiving aid from the state or international organizations in Badakhshan province, victims did not have the means to start over at their original place of residence. They needed to receive assistance, and the only place they could receive it was in southern Khatlon province. The state sculpted this as the only option since it ordered international organizations to only provide aid in the resettlement areas. AKF representatives in Khorog acted as messengers of the government's decision, and not in the interests of resettlers. This is in contrast to AKF representatives in Dushanbe who believed these resettlers were forced into resettlement, but nevertheless initiated a water transport campaign by which Ismaili Muslim resettlers could obtain water from a fresh water source. Although the opinions of AKF representatives differ, they all abided by their memorandum of understanding with the government and supported the relocation of those from Dasht. 
Other agencies were intent on assisting resettlers from Dasht and as such, were closely involved with resettlers. For example, the representative of Global Partners in Khorog stated that Global Partners provides aid when the citizenry needs it, regardless of the political situation. This organization helped recover the bridge in Dasht and offered to help resettlers in the resettlement area. Resettlers refused this assistance, revealing plans of leaving the resettlement area and stating that they prefer to receive this assistance after they move away. This representative contacts these resettlers periodically to inquire whether their position has changed. This reveals that resettlers can be agents in aid provision, which will be elaborated on more in Chapter 4 . The OSCE office is located approximately twenty kilometres from Beshkent valley, and as such it became a center of appeal for resettlers discontent with their situation. In this way the director became involved with resettlers. Although the OSCE could not provide aid to resettlement areas, the director donated a refrigerator, as well as his time and effort to help the resettlers adapt to their situation. He is in direct contact with resettlers and has been actively trying to improve their situation through appeals to other international actors and the municipal government for assistance.

Subtle forms of power are at work here. Some resettlers realize more is to be gained from appealing to international organizations than from appealing to the government about their living conditions. They act based on their perception of the high resource capacity of international organizations and low resource capacity of the state. This leaves these resettlers out of any pact with the state. 
The OSCE representative is able to use communication technology to contact acquaintances in the international community for this cause. He also has resources that he could donate to resettlement communities. However, he can also choose not to utilize the resources available to him since they are under his control.

Some resettlers have penetrated the sphere of international organizations in Tajikistan. Resettlers in Navruz and in Beshkent 2 established their own nongovernmental organizations. They received funding from international organizations to carry out projects in their resettlement areas. One group built a banya [public bathouse], while the other group had not yet begun to implement their project. This initiative will be discussed more in Chapter 4, however, it reveals an understanding on the part of some resettlers of how international organizations operate. Resettlers used this knowledge to improve their living situation and bypassed the state in doing so. In trying to improve their situation, resettlers learned confronting the state is futile and instead turned to international actors. This case shows that "[t]he realm of knowledge is an inextricable site of power in modernity" (Thomas and Wilkin 2004, 252), as resettlers improved their situation through knowledge about international organizations.

Although resettlers still hold the government accountable for not fulfilling their promises, the result of resettler contact with international organizations is that the state has to confront society less. Erika Weinthal concluded in her study of environmental organizations in Central Asia that

[t]he Central Asian governments' support for the linkage between transnational and societal actors prevents the state from having to confront society and also deflects society's criticism of the way the state is managing its environmental 
resources. As a result, transnational actors are contributing to the formation of a clear division between state and society, whereby the state is not embedded within society or society within the state (Weinthal 2004, 269).

This conclusion only partially applies to the situation in Tajikistan, where the state is embedded in many aspects of the daily life of its citizens, from water provision to the type of seeds available, despite the prominent presence of international actors.

The Tajik government is only one of several major actors in Tajikistan. Other countries have imported their presence through foreign aid, business investments or humanitarian activities in order to meet their security objectives. The state relies on international actors to step in and assist so that its capacity shifts from low towards high. However, an analysis of the results of aid provision in resettlement show that international actors are improving resettler capacity more than state capacity. Resettlers are also influencing this "strong-weak" balance, as they bypass the state and appeal to donors to improve their situation.

An analysis of the influence of international organizations on governance in Tajikistan should go past the mere presence of international organizations and look at the type and substance of their participation. In the case of resettlement, some international organizations were instrumental to the exercise of state power, while others tried to block it. Some were aiming to change state institutions and practices, while others were aiming to improve lives. International actors tried to shape the decisions of the state, as well as citizens. The agency and power of international actors to influence state policy is questionable since the state is continuing with resettlement, despite the concerns of some international actors. However, these concerns were never 
communicated to the government in a formal manner which could have influenced the government.

International actors react to government activities differently, demonstrating the existence of more than one 'international community' in Tajikistan. There are numerous aid organizations with a range of resources and types of activities they offer in Tajikistan. Aid coordination could simultaneously produce better living conditions for resettlers and improve state capacity. Yet the international community remains divided due to different approaches on humanitarian aid provision. 


\section{CHAPTER 4}

\section{SHIFTING GROUND: RESETTLERS AND RESETTLEMENT}

Resettlement areas are not visibly different from other rural localities in Tajikistan. Houses are in poor shape, cotton is the sole crop, donkeys are the means of local transport and kids are playing in the street. In all of rural Tajikistan fertile, irrigated land is limited, well-paid employment is scarce and the housing, education, health and water system have fallen apart. Most resettlers moved because they thought their life would be better in the resettlement area, but on arrival most resettlers faced conditions worse than expected. This generated a variety of responses. An examination of resettlers' outlooks and actions after resettlement reveals an interdependent, complicated relationship between resettlers and the state, international organizations, other resettlers and the host population.

This chapter will begin with an outline of the poor living conditions in resettlement areas. I will then show that this negative change in living conditions coupled with departure from their original place of residence has meant a loss of capital for resettlers and as a result, their livelihoods have been undermined. In outlining the various reactions and responses of resettlers to their living conditions, I will show that resettlers are not a homogenous unit. While some are state dependent and comply with resettlement conditions, others are agents defining the conditions of resettlement for themselves. Within all responses are aspects of state and resettler power, revealing that just as the state shapes resettlers, so do resettlers shape the state. 
The climate in most resettlement areas is difficult for newly resettled households. In southwestern Khatlon, where the bulk of resettlement areas are located, the climate is inhospitable as compared to the rest of Tajikistan. Summer temperatures soar to sixty degrees Celsius and rainfall is limited (Abdullaev and Akbarzadeh 2002, 29): this is in contrast to average summer temperatures in Badakhshan province of twenty two degrees Celsius. Southwestern Khatlon province is also host to strong dust-laden winds which lift topsoil, destroy crops, as well as tear doors and roof panels off of houses (Beshkent 1 Group 2004, Pirmatova 2004; Dashti Kozi Group 2004, Beshkent 1 Group 2004). Resettlers in northern resettlement areas experience lower summer temperatures and lighter winds than their counterparts in southwestern Khatlon, though otherwise their living conditions are similar.

Resettlement areas lack reliable sources of safe drinking and irrigation water, as well as sanitation facilities. In rural areas, the state first directs water to the cotton fields and citizens may access any remaining water at communal pumps or above-ground cement water canals. However, water circulates in these canals only for a short period during the summer and communal water pumps frequently break down and require repair, which takes on average fifteen days to complete (Sadulloev 2004). Despite repair, water does not flow out of some water pumps (Selobod Group 2004). In this case, resettlers usually obtain water by walking to the next village, filling pails from the local water pump and carrying the water back. Resettlers living in Beshkent Valley who have access to a vehicle may obtain spring water from a natural source within the Valley, named 
Chilichor Chashma; however none of those interviewed had private means to transport water from this source ${ }^{14}$. In winter it is even more difficult to find water in resettlement areas since the state limits electricity to a few hours in the morning and evening in rural areas. These water conditions are in contrast to those in Badakhshan province where most residents use mountain spring water in their daily routine. 'In Badakhshan, we had spring water that doesn't even compare to this water" (Chorshanbieva 2004). This is the same case for other resettlers, which mostly moved from the mountains to the valleys.

Such problems with water coupled with infertile land mean that resettlers have difficulty growing food on their land. All resettlers received land plots in addition to their household garden plots upon resettlement. In addition to being located several kilometres on average from their home, they are largely unworkable since the land is saline (Nazarov and Nosirova n.d.; ICG 2005, 27). Resettlers lack the finances to access inputs such as fertilizer, and having come from mountainous or urban areas, resettlers are untrained on how to work or revitalize such land. All combined, these conditions have led to unsuccessful harvests for most resettlers. The crops dry up because of a lack of water and only a small amount makes it to harvest (Beshkent 1 Group 1 2004, Chashma Group 2004, Sadulloev 2004, Beshkent 2 Group 2 2004). One resettler in Chashma commented, "Of course we had it better in Shurabad [our original home]. Coming here we counted on the fact that we would have an income after planting wheat. But it's the other way around. Although we planted wheat, we

\footnotetext{
${ }^{14}$ As mentioned in Chapter 3, for a short period of time representatives of the Aga Khan Foundation drove resettlers in Beshkent Valley from eastern Badakhshan province to access water here.
} 
have to buy it" (Chashma Group 2004). Resettlers in the resettlement locality Beshkent 2 reported the same. They moved in order to grow wheat, but they found out on arrival it was not possible because the land is infertile and there is not enough water (Beshkent 2 Group 2 2004).

Unable to reap a sufficient harvest from their land, and with a meager income from work in the cotton fields, food security is low in resettlement areas. Resettlers eat a starchy diet mainly composed of potatoes, bread and pasta. On average they eat meat twice a year on special holidays and rarely eat eggs or milk products. Many do not have a food reserve at home and some resettlers beg for food (Beshkent 1 Group 2004, Beshkent 2 Group 2 2004, Chorshanbieva 2004). A single mother of eight children reported, "We have been dying from hunger for two years" (Valieva 2004). Another resettler commented, "If we get water and the wind stops, then maybe we can grow something and have a chance at survival - enough wheat to feed ourselves. Without this, we are starving. We will die" (Chorshanbieva 2004). Several resettlers reported a loss in weight of all family members after resettlement and that their diet at their original place of residence consisted of more vegetables than in the resettlement area.

The change in climate coupled with unsafe drinking water and a poor diet has worsened resettlers' health. All resettlers reported a deterioration of their health condition since resettlement, though it has been worse for some more than others. "Our health has become worse here" (Beshkent 1 Group 2004). People complained mainly of headaches, kidney pain, high blood pressure, anemia, rashes, heart problems as well as instances of malaria, typhoid and 
tuberculosis. Malnutrition is also widespread and one resettler had a goiter (Pirmatova 2004). The health of children and the elderly has especially worsened. This had fatal consequences in one resettlement area when a newborn child passed away reportedly because of malnutrition (Chorshanbieva 2004). Other resettlers have died from intestinal diseases and an infection contracted after swimming in a canal (Mamadshoev 2002b). Hospitals were absent in all resettlement areas and access to medical services was limited due to a lack of public and private transportation. A study of planned resettlement in Laos also concluded that the health of resettlers deteriorates after resettlement. This study revealed that the health of resettlers is vulnerable during the first years following relocation, especially in resettlement from mountains to the plains (Evrard and Goudineau 2004, 948).

The quality of housing in resettlement areas is poor. All resettlers interviewed for this study have housing, though some were given abandoned homes that lack windows, doors, floors or a full roof (Barotov 2005). Faced with a lack of fuel to heat their houses during winter, some resettlers have used their floor for this purpose and live with dirt floors (White 2004). Others do not have the financial means to furnish their houses. Many resettlers complained their houses were damp, an effect of the high water table in resettlement areas. One resettler reported in 2004, "We moved here with my family in August 2002. We were promised conditions that would be like paradise, but there are no [viable] conditions at all here - it is very hot, the soil is saline, and the unfinished houses are damp" (Khairuddinov and Abdullaev 2004). Although some resettlers 
escaped crowded housing conditions through resettlement, the housing these resettlers received was in worse condition than at their original place of residence.

Schools vary according to resettlement area. Some resettlement areas have functioning schools with many grades while others do not. The resettlement villages Vashang, Beshkent 1, Navruz, and Dashti Kozi have schools that offer classes up to grade six. A resettler teacher in Beshkent 1 reported that all thirteen teachers resettled after the flood in Dasht were sent to Beshkent 1. This left a lack of teachers for Beshkent 2, where the state resettled other flood victims. One resettler reported that his daughter's reading abilities as well as her enthusiasm for learning have deteriorated since resettlement (Beshkent 2 Group 1 2004). Other resettlers in Beshkent explained that their children do not attend school because the family cannot afford clothing, shoes or notebooks for the children (Beshkent 2 Group 2 2004; Valieva 2004). Uzbek is the language of instruction at schools in Chashma and Beshkent 5, which are both located in the Beshkent Valley. Since resettlers are Tajik-speaking, their children do not attend these schools. One family sends their children to an internat (boarding school) in the town of Shaartuz, where the language of instruction is Tajik (Chashma Group 2004). Since the other family lives forty kilometres from Shaartuz, the children of this family do not attend school.

These living conditions are different from those set out in the resolutions governing resettlement. In terms of infrastructure, the resolutions state that the relevant government ministries are responsible for providing drinking water, 
electricity, medical centres, schools and public transportation between the resettlement area and the district center. The government ministries did not fulfill these responsibilities and the resettlement policy was not implemented as planned. Resettlers' reports of the living conditions compared to those laid out in the resolutions reveal a weak Tajik state unable to implement policy.

Resettlement has adversely affected the livelihoods of resettlers. According to Paul Chambers, "livelihoods comprise the capabilities, assets (including both material and social resources) and activities required for a means of living" (Chambers quoted in Meikle and Walker 2000, 37). Upon moving from one area to another, resettlers go through a double process: deterritorialization and reterritorialization. Deterritorialization consists of leaving a territory, but this departure also entails a change in way of life. Reterritorialization consists of settling in a new environment, as well as accepting and integrating into cultural references bound up with it (Evrard and Goudineau 2004, 938). Resettlers' livelihoods are undermined during these processes.

Sociologist Michael Cernea outlines several factors which diminish the capabilities, assets and activities of resettlers upon resettlement. These negative impacts of resettlement are: landlessness, joblessness, homelessness, social disarticulation, loss of access to common property resources, marginalization, food insecurity, health deterioration, increased mortality, issues of access to education, political expression and violence (Cernea cited in Meikle and Walker $2000,34)$. Landlessness refers to loss of land as a productive asset and investments made in improving land, joblessness is loss of wage employment, 
and homelessness can mean lack of a housing structure and/or a lack of attachment to the resettlement area. Social articulation refers to the destruction of existing social organization including informal and formal networks and marginalization occurs when families lose economic power and social standing.

Resettlers in Tajikistan were confronted by most of these factors and the result is diminished livelihoods. I have already outlined that upon resettlement most resettlers faced health deterioration, loss of access to common water resources, as well as loss of access to fertile land, inputs and equipment that guaranteed their food security. One resettler explained, "In Dasht we ate much better. In Dasht we also had a garden where we grew vegetables and wheat. The Aga Khan Foundation always helped us with seeds" (Pirmatova 2004). The agricultural knowledge and skills of most resettlers were less applicable after resettlement since the land the state resettled them to was of a different composition and they lacked the inputs they were familiar with.

Coping skills also became ineffectual. A representative of Global Partners, who works extensively in the eastern Badakhshan region remarked, "Life is not fun in the Pamirs [Badakhshan], but there these people had coping mechanisms that they don't have here in the desert without water" (Gamble 2004). Resettlers also endure 'joblessness' as the majority of them are not employed according to their profession in resettlement areas. Many resettlers work in the cotton fields and are underpaid, or not paid at all. As discussed in Chapter 2 the state failed to match professions of resettlers to employment needs in resettlement areas, diverting the labour force into the cotton industry. 
In addition to being jobless, resettlers are also placeless. Revealing their lack of attachment to the resettlement area, some resettlers refer to their previous residence as 'home'. "The living conditions at home were much better than here" (Mamadjanova 2004). Some resettlers idealize their previous place of residence. "In Vorukh it is heaven. There is no heat, it is never cold" (Sultanobod Group 2004). In addition, "Living conditions here are horrible compared to the living conditions we had in Dasht" (Beshkent 121 October Men). Resettlers also imagine a land of fruit and plenty there. "At home in Vorukh, we ate better since we grew almost all vegetables and fruits ourselves" (Sultanobod Group 2004). These positive images only improve over time since most resettlers are financially unable to return 'home'. As James C. Scott concluded in his study of the peasantry in Malaysia, "They have collectively created a remembered village and a remembered economy [emphasis original] that serve as an effective ideological backdrop against which to deplore the present... It is only now that the revalued past has become necessary to assess a menacing present" (Scott 1985, 178). The same applies here. Resettlers' memory is selective, not faulty. What they choose to remember helps them assess their situation. As anthropologist Elizabeth Colson concludes, "The ethnographic record points to camps and resettlement communities as seed beds most conducive to the growth of memory and the pursuit of the myth of return" (Colson 2003, 9). Unattached to the resettlement area and calling their former place of residence 'home', resettlers are "placeless" (Cernea 1995). They are physically away from home and mentally away from the resettlement area. 
Some resettlers also faced social disarticulation after resettling. Resettlement disrupts existing communities and networks, leading to social disarticulation. Social disarticulation is the "destruction of the existing social organization including both informal networks, such as family of neighbourhood networks based on friendship, and formal networks such as community based organizations and traditional leadership structures" (Meikle and Walker 2000, 36). For the most part, the state sent people from the same villages to different resettlement areas. This fragmentation of neighbours led to the physical disconnect of the original community and members lacked daily access to the social capital of their network. There was also no evidence of new social capital being built up between resettlers and members of the host population. Most reported good relations with their neighbours in interviews, but one group of resettlers reported that the host population was bitter that resettlers took their land (Oltynsoi Group 2004). Indeed, the competition for scarce resources is greater with the arrival of resettlers, leading to hostile host populations. "Uprooting has massive impacts across a whole spectrum of populations. Arrival as well as departure poses threats to communities and established definitions of self" (Colson 2003, 11). One resettler commented that their neighbours are "all strangers" and that because of that he cannot ask them for help (Saidov 2004). The result is social disarticulation of citizens.

Resettlement has also produced mixed results in terms of ethnic relations. These relations are most evident in the Beshkent Valley, the most ethnically diverse area to which the state has resettled people. Although most resettlers 
commented that relations with the host population were amicable, one group reported tensions between a host Uzbek population on one hand, and a Pamiri and Tajik resettler population on the other. Pamiri resettlers report problems with neighbours, many of whom are Uzbek host residents. "The Lokays, the longestablished local residents, often deride us, provoking us into fights and harassing our young women...A girl was raped recently, causing a storm of indignation among the Pamiris" (Khairuddinov and Abdullaev 2004). These hostile relations and act of violence are also negative impacts of resettlement.

Resettlers also build positive relations with each other. In Beshkent 2, Kulyabis and Pamiris banded together to repair their houses. Anthropologist Anthony Oliver-Smith writes, "[t]he affective ties between individuals and communities and their material environments are destroyed by uprooting and resettlement" (Oliver-Smith 1991, 2). This study revealed the opposite. The common experience of relocation drew resettlers together in solving common problems. Also, social capital was maintained despite the geographical fragmentation of neighbours. Resettlers from the same original place of residence who resettled in areas close to each other shared information, loaned each other money and gave each other food in times of need.

Villages resettled together fared better than communities that were dispersed among different locations. Two group resettlement villages in Navruz and Vashang took the initiative to improve their living conditions through negotiations with the state or by creating a non-governmental organization and securing funding from international donors. In both areas, resettlers took action 
as a group. The pioneering spirit of the group in Navruz was evident from the beginning. On arrival they found tents instead of houses in the resettlement area and so they educated their children in the tents. This group also pools their money together to pay for gas for the village ambulance (Chorshanbieva 2004). According to Barnes, total power is considerably increased if there is a group of individuals who have knowledge and act and interact coherently. A group's capacity for action is larger and wider ranging than many isolated individuals (Barnes cited in Haugaard 2002, 123). This shared distribution of knowledge gives rise to a capacity to carry out routines and execute projects in concert, which is an added capacity for action (Haugaard 2002, 124).

Resettlers in Tajikistan face landlessness, homelessness, social disarticulation, loss of access to common resources, food insecurity and health deterioration, all of which undermine their livelihoods. These factors work as a system, mutually reinforcing one another. Development planners Sheilah Meikle and Julian Walker explain:

[F]or example, poor housing may affect health which will in turn affect the capacity of resettlers to earn a living - and decreasing income may continue to affect health and nutritional intake. The depletion of one set of assets (social capital, for example, or housing) can thereby reinforce the depletion of another asset. If unchecked this kind of negative system can lead to a downward spiral of deprivation for resettlers (Meikle and Walker 2000, 37).

Resettlement involves radical changes as people are uprooted from their familiar circumstances. Whole communities suffer degrees of disintegration as social networks are dispersed to different resettlement sites.

Despite being confronted with these negative factors, not all resettler livelihoods were undermined. Some resettlers are content with the terms of 
resettlement and the living conditions in the resettlement area. Most resettlers eventually received transport to the resettlement area as well as land, housing and financial credit, all at the expense of the state. Good relations with neighbours are also keeping people in resettlement areas. Resettlers help each other out, lend each other money and in one case, marry members of the host population (Beshkent 1 2004, Sharipov 23 September 2004, Sadulloev 23 September 2004, Sattorov 2004, Chortimur Group 2004). One resettler in Karadum previously lived in a garage in Kulyab city. In terms of housing, she considers her life is better in the resettlement area and that she will stay. Another resettler in Karadum explained that there was no work and no room to live with his family at his previous residence. He is a tractor driver in the resettlement area and has been successful in growing some vegetables in his personal garden. Resettlers in Vashang say they will stay in the resettlement area because they have access to fruit that they did not have access to in the mountains. Others in Navruz asked, "where would we go?" and continued that they have already adapted to life in the resettlement area. Living in areas safe from natural disasters was also a factor keeping people in resettlement areas: "Now, no one is worrying" (Sadulloev 23 September 2004). Resettlers in Dashti Kozi and Shakhbur expressed the same sentiment. Others believe they will reap three harvests a year and commented "this will help us feed our children better than we have ever been able to before" (Mamadshoev 18 June 2002). Overall, movement to the resettlement area has improved the life of these resettlers, who are motivated to stay there to meet the basic needs of their family. 
Survival is also the motivation of other resettlers who reported that they wanted to return to their original place of residence. The majority of resettlers reported that their life is worse in the resettlement areas. One resettler remarked, "There are more problems here than hairs on my head" (Oltynsoi Group 2004). When asked whether they prefer life in the resettlement area or at their previous place of residence, most resettlers responded they preferred living at their original place of residence. This was an obvious answer to most resettlers. "In Kanibadam, of course there are better living conditions" (Muroteppa Group 2004). Another resettler responded, "it is not possible to live here... How will we live here? We are people after all" (Saidov 2004). When asked whether they preferred to leave or stay in the resettlement area, almost all resettlers said they would leave if they had somewhere to go and the means to get there (Chashma Group 2004, Beshkent 1 Group 1 2004). However, they also replied that if the state improves their living conditions they will stay. "But if they create good living conditions, we will of course stay" (Mamadjanova 2004). Others would stay if they had access to drinking water. "If they turned on the drinking water, it is possible that no one would leave from here" (Selobod Group 2004). Some were more definite about leaving, revealing their plan of repaying the credit at the five-year point with remittances from their son working in Russia (Beshkent 1 Group 2004).

Still others stay in resettlement areas because they lack the means to leave. Having lost their houses and land at their original place of residence due to natural disasters, they are unable to return there. Unable to receive land 
elsewhere due to a state monopoly on land, resettlers "stay in the resettlement areas as serfs to the cotton [farm]" (Gamble 2004). Some resettlers replied they would like to work in Russia, but they do not have the financial means to do so (Chorshanbieva 2004, Chashma Group 2004). Others replied they would have more problems if they were to leave since they would have to secure housing, land and employment in another area. One representative of Global Partners summarized the situation: "If it was easy to move, no one would be in Beshkent. People lost everything. It takes a lot to bring people up from that" (Global Partners Khorog 2004). Lacking any realistic possibility of redressing their situation, they have little choice but to adjust to the circumstances they confront daily.

Acknowledging the poor living conditions in resettlement areas, resettlers blame different people for their situation. Some resettlers blame resettlement disorganization on the fact that no single coordinating body took responsibility for the move (Mamadshoev 18 June 2002). "They always make promises, but you can wait as long as you want and you still won't get any real help from them" (Khairuddinov and Abdullaev 2004). Others blame themselves for the conditions they find themselves in. "No one fooled us into coming here. We fooled ourselves" (Oltynsoi Group 2004). Another resettler commented, "it turns out we were mistaken" (Rushanova 2004). Some resettlers blame the government. "They lied to us, they lied. Everyone here will die if this doesn't change" (Kurbonova 2004). "It was all a lie", replied one resettler referring to false 
promises of good land and assistance (Esoev 2004). Some believe the government lured people to Beshkent with false promises (Sayf 12 August 2004).

Many resettlers have lost hope in the government. A resettler in Dashti Kozi commented, "the construction of homes is going very slow and people have lost faith that they [the government] will help and support us" (Dashti Kozi Group 2004). Others are tired of waiting for the government to deliver on its promises to provide adequate living standards - "I want to ask the government to move us away from here to other places, preferably the Pamirs and help us with housing" (Khairuddinov and Abdullaev 21 May 2004). As Scott writes about the rich and poor of Malaysia, when people try to make sense of the massive changes that they have experienced the result is a struggle over the facts and their meaning, over what has happened and who is to blame, over how the present situation is to be defined and interpreted (Scott 1985, 178). It is convenient to blame those who are most immediately and directly responsible for their recent reverses (ibid., 182).

Just as resettlers have different opinions on whether they will stay or leave the resettlement area and who is responsible for their situation, they also exhibit a range of responses in dealing with the poor living conditions. While some resettlers depend on the state to improve their situation, others articulate their autonomy from state control and attempt to improve their situation independently. This articulation can occur due to the low financial and institutional capacity of the Tajik state, but also because resettlers utilize their personal capacities and resources to achieve desirable outcomes. As a result, resettlers at once 
undermine and enforce the resettlement programs. The discussion will now focus on reasons for resettler compliance and resistance to the rules and conditions of resettlement and what this reveals about the power of the state and resettlers.

Resettlers comply with the conditions of resettlement because the state has succeeded in transforming them into subjects of state control and dependence. Soviet rule shaped the expectations of the citizenry and created citizens' dependence on the state. These expectations and dependence persist in Tajikistan. Citizens depend on the state on a daily basis for water, land and electricity. Using its infrastructural capability to allocate such resources, the state controls the everyday life of citizens. It controls what land can be used, when it can be watered, with how much water, when citizens can use electrical appliances and for how long. The state controls citizens' opportunities by limiting their access to these scarce resources.

In addition to being dependent on the state for these basic resources, resettlers also still expect the state to provide for their basic social and economic needs. The information state officials gave to resettlers about the conditions of resettlement perpetuates these expectations. State officials told resettlers that the state would supply transport, financial credit, employment and land, as well as water, electricity, schools and a medical centre in the resettlement area. Resettlers' expectations are based on this information, but also on their own habits. My interviews revealed that having always expected the state to provide 
for them, most resettlers could imagine no alternative to this and they therefore continue to have this expectation of the state.

Such dependence on the state has produced a passive citizenry, which is evident in resettlement areas. Resettlers in Beshkent reported that living conditions were much worse than they expected, and they commented that the "government has done little to make our lives easy or even sustainable" (Khairuddinov and Abdullaev 2004). They trust that the state will provide for them. "The state promised that in the near future they will create all of the living conditions and that we will have irrigation water. And we believe in the state, that everything here will gradually normalize" (Rajabov 2004). Power is visible here in the regularity of behaviour of the state and citizens as both actors do not evaluate the structures they are acting within (Holzschleiter 2005, 735). Both the state and citizenry are playing their traditional roles of provider and receiver respectively. In this they are reproducing the practices and expectations of each role, all the while maintaining state control of the citizenry.

The resettlement process acts to cement these roles. In a study on resettlement, anthropologist Elizabeth Colson found that most Zambian subsistence farmers suffered an initial period of shock as they were torn out of their familiar environments, and were unwilling to take risks in the first several years after resettlement (Colson 2003, 13). Anthropologist Jonathan Habarad also found that lu Mien refugees from Laos were averse to experimentation after resettlement in the United States (Habarad cited in Colson 2003, 9). In resettlement, people and their identities are uprooted. The upheaval of 
resettlement leads to an environment conducive to the continuance of already established roles and identities. Colson explains,

Theoretically we would expect a period of a hiatus after the shock of uprooting. Since people define themselves in terms of the roles they play and it is thus that they are evaluated and valued, the loss of role structures means that they cannot know who they are or who anyone else is until new roles are constructed and people assigned to them. It takes time to assess the loss of old roles or their transformation. It takes time to renegotiate relationships. All this involves processes of adaptation (Colson 2003, 8).

For those whose new hopes are thwarted, or who have little control over what happens, "hope and experimentation lapse into further despair and apathy" (ibid., 9). The result is a lack of initiative while resettlers wait for the state to improve their situation.

Not all resettlers play a passive role, though. Some resettlers negotiated with the state to improve their living conditions. Arguing that they live in desertlike conditions with no surrounding vegetation to use as fuel in the winter, one resettlement village negotiated three years unlimited, free electricity with municipal government officials (Sadulloev 2004). This group was also able to negotiate a bus from the state since there is no public transport through or to this village. Although the relevant local state officials were unavailable to comment on these negotiations for this study, I believe resettlers were successful in their negotiations because they approached the state with plausible grievances which limit their settlement in the area. In providing electricity and a bus, the state is not only living up to its responsibilities laid out in the resolutions, it is also providing incentives to ensure resettlers remain in the resettlement area. This particular resettlement area is also less than ten kilometres from the border with Uzbekistan and as such, plays an important role in 'Tajikifying' the borders. 
Therefore negotiations may also have been successful because the resettlement area is strategic in meeting the state goal of securing its borders.

Recognizing the lack of fuel sources in the resettlement area and the lack of public transport to find fuel sources elsewhere, as well as that the state wants resettlers to remain in the resettlement area, these resettlers were able to negotiate with the state and gain improved living conditions. These materially weak actors can exploit possibilities by organizing and aligning themselves into larger groups propagating a single opinion (Holzschleiter 2005, 736). Their strategy of action was based on their acknowledgement of state objectives, holding the state accountable and acceptance of the idea they could act as agents themselves. Although these resettlers are subjects of state control and dependence they were able to imagine different modes of interaction with the state and act out an alternative to the passive role played by other resettlers. In this way they are utilizing their capacity to negotiate in order to achieve their desired outcome.

Resettlers in Chapaev reported that they too negotiated with the state. However, their negotiations were not successful. After suffering a landslide in their former village Kamar, the state offered to resettle these residents to Beshkent Valley or Kumsangir. Selected members of this community visited these areas in order to make their decision. On return they all agreed to not resettle to the proposed areas, but to negotiate Dzherkala as their resettlement area. This town is closer to their original place of residence and according to them, has acceptable infrastructure. Local state officials refused to resettle them 
to Dzherkala and "forced" them to settle in Chapaev, which is a village ten kilometres from their original place of residence (Chapaev Group 2004). These local state officials were also not available for an interview for this study. Having visited the area, I suspect resettlers were likely unable to negotiate their resettlement to Dzherkala because of a lack of available land for housing there (Dakhana 2004). These resettlers did not entirely lose in the negotiations, as they were able to resettle within the same district as their original place of residence.

Some resettlers appealed to the central state to improve their living conditions. Residents of Beshkent 2 wrote complaints to the President as well as the Ministries of Labour, Health and Education about the poor living conditions in resettlement areas (Sayf 2004). At the time of interview, they had yet to receive a reply from these ministries. Resettlers also approached the Beshkent municipal government with their complaints, but these state officials denied the problems existed (ibid.). Resettlers used this strategy because it is common practice for interacting with the state in Tajikistan, learned from Soviet times. I could not ascertain whether it was a result of these appeals that the prime minister visited Beshkent Valley and attempted a dialogue with resettlers. At the end of the meeting, the prime minister stated he would order the water infrastructure to be fixed, part of which was completed in 2004 .

Other resettlers took the initiative to improve their living conditions themselves, rather than appealing to the state. As the sole resettler in one village and uncertainty about when the next resettlers would arrive, one man 
realized it was futile to wait for the state to provide his household with electricity and water. Therefore he wired electricity and extended a water pipe to his house (Sharipov 2004). Similarly, in Selobod resettlers pooled their money together to buy a water pipe. "With our own means we connected a water pipe from the village Oshoba" (Selobod Group 2004). These resettlers exhibited the capacity to act outside of the traditional 'receiver' role played by the citizenry. They also managed to use their skills to their benefit. Skills are a potential power resource. Two people may possess the same skill but depending on their motivation as well as if and how they employ that skill they will exert different power. One person may use skills to increase their power, the other may not. In the case of these resettlers, they employed technical and group skills to improve their living situation.

Resettlers require the means to improve their situation, but also the mindset. "We are doing everything with our own hands, we are working for the improvement of our living conditions. What depended on the government helped us, and the rest we have to create for ourselves" (Dashti Kozi Group 2004). Resettlers in Navruz have a similar independent attitude. "Gradually we established ourselves. We gradually started to collect a harvest...all women and men on Saturdays worked as subbotniki [volunteer workers], cleaned up and helped the construction workers...But we hope that this is a temporary thing, that we can gradually be able to build ourselves big houses" (Chorshanbieva 2004). This attitude helps these resettlers improve their living conditions. 
State information controls resettlers. Those without financial resources to travel to potential resettlement areas or who did not have access to first-hand information from neighbours or relatives, relied on the information they had from the state to make their decision. Although some state officials provided accurate information, many resettlers did not have an accurate impression of the area before arriving. Indeed, some resettlers had the information all wrong. When state officials proposed resettlement to Beshkent to people in the town of Shurabad, they understood this resettlement area was in Kyrgyzstan. It was only after arriving in Beshkent that they understood Beshkent is a district in Tajikistan (Chashma Group 2004). Others thought they were going to the center of Beshkent district, Shaartuz, or to a village close to Shaartuz such as Beshkent 1, but they were actually brought to Beshkent 5 , approximately forty kilometres from Shaartuz (Saidov 2004).

Given the dire living situation in Tajikistan, many people are willing to move on the prospect of receiving land. One man considering resettlement from Ishkashim in eastern Badakhshan province admitted he would be willing to resettle across the country if it meant he could feed his family (Nurov 2004). However, this readiness to move is entirely based on the information resettlers received from state officials. This shows the appeal of the resettlement programs, but it also reveals a non-questioning citizenry that readily accepts information from the state as true. These resettlers do not imagine seeking information on resettlement areas themselves. However, it could be that these 
resettlers lack the means to access other information sources. Therefore, the means and mindset of resettlers is important in an analysis of their actions.

State information about resettlement areas is usually uncorroborated, old and embellished. This state information feeds the general mindset among citizenry that conditions are poor where they are living and by default, better elsewhere in the country. This is a problem in Tajikistan, where information exchange among state departments is not coordinated and the state lacks the finances to obtain current information. In telling citizens inaccurate information, the state is exploiting resettlers' poor financial position in order to enforce the policy. At the same time, making the decision to resettle based on inaccurate information undermines resettlement since the person may have made a different choice had they been given accurate information. State officials and resettlers work and live according to and make decisions based upon myths of resettlement area conditions without verifying this information for themselves. In effect state information is power at work as they motivate state officials and direct the citizenry.

Alternate information sources were available to resettlers who had the means to access them. In some cases, the relatives or acquaintances of the resettlers lived in or near the resettlement area and potential resettlers received information from them about the resettlement area (Shakhbur Group 2004, Karadum Group 2004, Beshkent 2 Group 2, 2004, Muroteppa Group 2004, Chortimur Group 2004). Village leaders from Vashan gathered the means to travel from village members, visited the potential resettlement areas and filmed 
videos of the resettlement area conditions at each location to show potential resettlers. Still others moved within the same district close to their original place of residence and therefore knew what they could expect (Dashti Kozi Group 2004). In these ways, some resettlers had an accurate impression of the resettlement area. For the most part, people received this accurate information from their relatives, neighbours or acquaintances, not from the state or international organizations. With the initiative and the means to obtain information, these resettlers made informed choices on resettlement.

The government secures compliance from resettlers on employment in the cotton industry by failing to organize employment according to profession in the resettlement areas. Although some teachers and nurses were able to find employment according to their profession in the resettlement area (Beshkent 1 Group 2004, Pirmatova 2004, Sixty Years of Border Troops Group 2004, Beshkent 2 Group 2 2004, Sadulloev 2004, Oltynsoi Group 2004), and two resettlers became state agents in the resettlement area, working as a policeman (Chortimur Group 2004) and the Beshkent Valley representative for State Migration Services (Barotov 2004), many resettlers were left unemployed since the demand for their professions in resettlement areas was low. As explained in Chapter 2, without having found employment in their profession, many resettlers turned to employment in the cotton industry in order to earn an income. The cotton industry was the only source of income in nine resettlement areas (Chorshanbieva 2004, Beshkent 2 Group 2 2004, Selobod Group 2004, Oltynsoi 
Group 2004, Saidov 2004, Rushanova 2004, Sultanobod Group 2004, Shakhbur Group 2004).

The inaction of the government to organize employment for resettlers according to their profession as promised makes diversion of resettlers to the cotton industry more probable. However, resettlers readily accepted the information from state officials that they would be able to find employment according to their profession in resettlement areas without verification or question. Here the government is exploiting resettlers' dependence on information from state officials as well as the regularity of government-organized employment and the non-questioning aspect of the citizenry. In exercising its capacity to exploit these elements, the government achieves its desired outcome.

Resettlers pick cotton despite receiving a measly, irregular payment. Depending on the resettlement area, resettlers reported that they are entitled to receive from CAD $\$ 0.01$ to 0.03 per kilogram of cotton they turn in. However, in no instance did resettlers receive what they deserved. In Beshkent 2, cotton workers collectively received sixty two kilograms of corn as partial payment for the cotton they picked during the harvest (Oxfam 2004), while in Selobod workers received soap and oil (Selobod Group 2004). Seventy per cent of women working in cotton in Beshkent district work only to collect the cotton stalks after the harvest, which they use for cooking and heating their houses in the winter season (Oxfam 2004). Cotton stalks are also another source of income, from which people earn a maximum of CAD\$20 per season (Oxfam 2004). 
These workers are paid in kind because the farms are in debt. One resettler explained:

All the state farms and collective farms that exist here, they are in debt to other organizations. So working in the cotton fields, it is certain that you will not be paid for your work, but they will give you a liter of oil, a little flour and soap... High school teachers, working for the state, have not received their salary for 5 months now. If the collective farm is giving food instead of a salary, then no one here is receiving any kind of income (Selobod 2004).

An Oxfam report explained, "Even though the payments are very low women prefer to pick cotton, as they sit at home and don't have any other paid work to do" (Oxfam October 2003). As Erika Weinthal concluded, the "reliance on cotton exports for foreign revenue has served as a mechanism for social control [in Central Asia]" (Weinthal 2004, 260). In limiting employment options in resettlement areas and denying resettlers their due payment, the state is controlling the finances and residence of resettlers.

Some resettlers refuse to work in the cotton industry even though there are no other opportunities to gain income in resettlement areas. Women in Beshkent 2 reported that they refuse to work in cotton since they are rarely paid and even if they are paid they receive CAD\$ 3.70 to 5.50 per month (Valieva 2004). The situation is the same in Selobod. Few people work in cotton because of the miserable wage and because they have children to look after. These resettlers rely in remittances for labour migrants to survive.

The state constrains resettlers' departure from the resettlement area by requiring that resettlers remain in resettlement areas for a fixed period of time. Some resettlers are obeying the five-year residence rule, and thus complying with state policy. Resettlers in Beshkent 1 responded that they will remain in the resettlement area as agreed for five years, but at that point they will repay the 
state the credit they owe it using remittances from their relatives working in Russia. Another resettler responded, "but to leave just like that, it's of course forbidden since we came here on an agreement, we said that we would work" (Sultanobod Group 2004). All of the resettlers are registered in the resettlement areas except for one family, which is waiting to be registered. These resettlers are following the rules set out in the government resolutions for resettlement and in this way they are enforcing resettlement. In asserting control over the movement of resettlers, the state restructures, imposes order upon and sets boundaries around society (Mann 1986). This rule forbids the departure of resettlers and confines them to the resettlement area. As subjects of the state, resettlers obey this rule and in this way, the state secures compliance with the resettlement scheme.

Settler compliance is therefore based on the generalized state capacity to direct the citizenry. Parsons writes "the capacity to secure compliance must, if it is to be called power in my sense, be generalized and not solely a function of one particular sanctioning act which the user is in a position to impose, and the medium used must be 'symbolic'" (Haugaard 2002, 78). This capacity to secure compliance relies on the unwavering and longstanding habits and roles of both the state and citizenry. In describing a resettlement scheme in Zimbabwe, sociologist Alison Goebel concluded

Resettlement is nothing if not a 'modern development project' of the state, designed in part to redress past land injustice, but also to promote successful 'modern' small-scale farming among the African peasantry. Within this victory for modernity can be read the success of state power to 'discipline' the bodies and minds of resettlers (Foucault 1979). As such, settler compliance becomes an aspect of state power, rather than merely its effect [emphasis mine]. Settlers are not only 'oppressed' by the state-imposed rules and practices of modern farming 
in conservation, but they internalize the values, and become a part of the power/knowledge nexus of modern developmentalism (Goebel 1998, 299).

Resettlement in Tajikistan can also be considered an effort of the state to 'discipline' the minds and bodies of resettlers. It disciplines the minds of resettlers by shaping their expectations of resettlement through promises and by acting as the main, and sometimes only, information source for resettlers' knowledge of resettlement area conditions. It also disciplines their bodies through residence rules which act to keep them confined to resettlement areas, by diverting them to employment in the cotton sector and through limiting agricultural productivity by not providing water for personal land plots.

However, the state is not disciplining the minds and bodies of all resettlers. With such bleak employment prospects in the resettlement areas, many resettlers violated the five-year residence rule to search for work elsewhere. State officials acknowledged in interviews that resettlers are leaving resettlement areas because of the low cotton wages, as well as because they originate from non-cotton growing areas (Latifov 2004). In practice, only some resettlers had ventured to the district center or Dushanbe. Most reported that the employment situation was just as dreary outside of the resettlement area, except for one man who had found work as a mini-bus driver in Dushanbe. All resettlers responded that the majority of young male resettlers had left the resettlement areas to pursue work in the Russian Federation. Sometimes this also included the older male population, leaving a largely female population behind in the resettlement areas. In some cases, as many as ninety per cent of the male population of the resettlement village is working abroad (Selobod Group 2004; 
Vashang 2004). This situation is not particular to resettlement areas, as mentioned in the introduction to this study.

Departure to seek employment elsewhere is a tool of resistance for resettlers. Anthropologist James C. Scott identifies flight as an "everyday weapon of resistance" used by the peasantry in Malaysia. "When flight is available - to the frontier, to the cities - it is seized" (Scott 1985, 349). Scott writes that an everyday weapon of resistance is an action that is unorganized, individual, unsystematic, opportunistic, and self-indulgent, with no revolutionary consequences and implies an accommodation with a system of domination. Labour migration from resettlement areas in Tajikistan is one such weapon of resistance. It is an avoidance protest of state policy. Unable to earn an income in Tajikistan, resettlers leave the country to find work elsewhere. Labour migrants from resettlement areas also practice evasion, another everyday weapon of resistance. They live abroad, but remain registered in the resettlement area and so can claim international assistance when present. In this way, resettlers are agents with the capacity to secure a better income for themselves. In exercising this capacity, resettlers are acting on government inaction to provide them with employment according to profession, as promised.

Labour migration from resettlement areas is both undermining and enforcing the state resettlement policy. On one hand, people are disobeying the five-year residence rule and leaving resettlement areas for extended periods of time without de-registering. As a result, they are neither part of the cotton labour force in resettlement areas, nor part of the citizenry there to 'Tajikify' the border. 
Labour migration abroad is also undermining state resettlement because the remittances earned from this migration are in some cases financing the departure of additional resettlers from the resettlement area back to their original place of residence or elsewhere in Tajikistan. However, remittances are also being used for daily subsistence in resettlement areas and in this way labour migration is ensuring that resettlers can purchase their basic necessities and remain in the resettlement areas.

Resettlers exercise other forms of mobility from resettlement areas. Despite the registration of the entire family in the resettlement area, some resettlers are maintaining two residences. Resettlers in Dashti Kozi reported that they use the house and land at their old residence three times per week in the fall and winter, and relocate there completely in the spring and summer. Interestingly, these resettlers suffered a landslide at their previous residence and according to the government resolutions, they should have disassembled their houses and moved entirely to the resettlement area. Likewise, a young couple that resettled to Beshkent 2 regularly return to visit their family at their previous place of residence when they have run out of food. Relatives' remittances from working in Russia finance this trip. With access to another residence, resettlers are not confined to their home in the resettlement area and can therefore decide their availability for work in the cotton industry. Whatever the original living conditions, the possession of another dwelling in resettlement areas is a relief for some resettlers from natural disasters and familial tension. The 'double residence' is also evidence of resettler resistance and compliance. Here they 
employ flight, evasion, non-compliance and compliance. Resettlers leave the resettlement area while remaining on the register as required, but they maintain and visit their previous place of residence, which according to state policy must be disassembled.

Rather than maintain a 'double residence' some resettlers opted for noncompliance and completely departed from the resettlement area. In Chashma, resettlers took this decision soon after resettlement. "Many left from here because normal living conditions were not created for them, there were not enough houses, people were living here in field camps which were not fit for living. Many children became ill and they left" (Chashma Group 2004). People left Beshkent 1 also because of the living conditions on arrival in the resettlement area, as well as their worsened health conditions. Some resettlers left Navruz because coming from Badakhshan province, they were inexperienced in agriculture (Vokhobov 2005). A family resettled to Beshkent 2 returned to their original place of residence in the eastern Badakhshan province. They too financed this trip with remittances from a relative working in Russia (Rushanova 2004). Resettlers with financial capacity are able to practice non-compliance.

It is typical that resettlers secure the finances for their mobility through family or neighbourhood communities, which are effective shock-absorbing units as the state functions under low capacity. In one family, thirteen members arrived in the resettlement area and only four members remain. With a lack of financial and institutional means to track these resettlers, the state cannot prevent people from leaving. Elements of resettler power emerge here. 
Resettlers surface as the dominant actors who are able to articulate their own movement with the state present only as an observer. Scott writes that "The parameters of resistance are also set, in part, by the institutions of repression" (Scott 1985, 299). Non-compliance is possible because of the weak institutions to track resettlers in Tajikistan.

These examples of mobility show that the 'settling' process promoted by the state paradoxically generates unplanned and unexpected further migrations. In moving away from the resettlement areas, resettlers are independent agents utilizing their capacity to improve their own situation. This is possible due to low state capacity for enforcing the residence rule. They disregard the limitations placed on them by the state, reinterpret the rules for themselves and produce new realities in order to improve their living situation. Resettlers have agency which leads to fragmentation of social control. The state seeks to mobilize people and resources and impose a single set of rules, but some resettlers apply different interpretations of the rules. In this case power does not repress or conceal, it produces. Resettlers exercise their autonomy vis-à-vis state resettlement policy by seizing opportunities available for mobility and by using personal and institutional networks to do so. They act on a terrain that contains limits as well as possibilities. These resettlers actively negotiate the social world rather than act out a script dictated by the state.

Another weapon of everyday resistance in resettlement areas is theft. Resettlers also reported that people are stealing this low yield from their fields, and they believe it is the work of individuals (Pirmatova 2004). However, some 
resettlers admitted that they are stealing melons from their Uzbek neighbours (Beshkent 2 Group 2 2004). This reveals the low food security and mobility of the village population as well as the weakness of rural police units. The targets are both resettlers and host residents. Both groups have something worth taking, but it is not clear which group(s) are doing the taking. Resettlers have the greatest incentive to take since they lack the animals that the host population has. In any case both groups are pitted at each other and this raises tension in the resettlement area and undermines resettlement policy.

The state also gains compliance because resettlers lack capacity in several areas. Resettlers from mountainous areas often did not have the expertise to work the land in resettlement areas. "The land was different in Badakhshan. We don't know how to work this land" (Etimov 2004). Other resettlers who moved from urban centers to rural resettlement areas had never worked in agriculture before and with no employment prospects in their profession in the resettlement area, these people were ushered into working in the cotton fields. Therefore moving people from mountainous and urban areas that lack the ability to produce food for themselves in the valley, provides an untrained labour force for the cotton industry.

Resettlers also lack an awareness of their land rights. A report by a government program set up to promote gender equality revealed that many rural women are unaware of their economic rights and their rights to use land (Kasymbekova 2005). Most resettlers interviewed for this study were confused as to whether they could sell the land they received on resettlement. This 
general unawareness of personal rights is also a lack of capacity to determine one's situation. Resettlers must acquire the capacity to work the land and to negotiate the use of the land. For many, this capacity does not simply exist. They acquire this capacity through gaining knowledge, and this capacity serves as power when it is used to purchase or sell land. Equipped with this knowledge, resettlers may be able to reap a harvest and may be able to grow crops leading to food security for their families.

Resettler capacity is also determined by international organizations, whose assistance promotes dependency among some resettlers. The actions of international and non-governmental organizations towards resettlers are enforcing the state resettlement policy. All resettlers reported that they had received some sort of assistance from at least one organization after resettlement. Local organizations included the local prosecutor's office, Beshkent municipal government, a mosque and a textile combinat. Aid came mainly in the form of food, medicine, water and mosquito nets. Other assistance included school repairs and animals on loan. Some resettlements received more assistance than others and some assistance programs targeted only the resettlement population, leaving out the host population (Beshkent 2 Group 2 2004). As mentioned earlier the AKF transported water only to Ismaili resettlers in resettlement villages in Beshkent district.

Aid provision also reveals an aspect of the relationship between the state, resettlers and international organizations. Resettlers who have left the resettlement area permanently or temporarily purposefully remain on the register 
so that they can return and receive aid. International organizations accept residence registration lists as true, and since the state lacks the financial and institutional capacity to track resettlers, resettlers can leave and return to receive their aid. Resettlers again use their power of movement to survive, but also their abilities to deceive and evade. Weinthal found that when state cannot or chooses not to fulfill expectations for provision of social welfare and environmental protection, societal groups may turn to actors beyond the state to fill this void (Weinthal 2004, 270). This assistance acts as a subsidy for the cotton industry. It keeps resettlers in the resettlement area and working in cotton. Weinthal suggests that transnational actors should empower societal actors to hold state actors accountable for their commitment. By receiving assistance some resettlers have developed a dependency on the assistance provided by international organizations in addition to a dependency on the state.

Society shapes state as state influences society. The Tajik state does not have a meaningful influence over all resettlers. Professor of international studies Joel Migdal argues that state control of society is reflected by three factors: compliance, participation and legitimation (Migdal 1988, 32). In situations where the population conforms to the demands of the state, is involved in state-run or state authorized institutions and the population accepts the states myths and consequently, the state's desired social order, Migdal argues the state has strong control over society. He adds that the weakest states are those where intentions of state leaders coincide the least with the actual rules by which people abide (Migdal 1988, 241; ibid. 259). The state is not able to control all the 
consequences of resettlement. This is largely because the level of technical assistance provided by the state to the resettlers is still very low, and much lower than is needed by the ambitious resettlement plans. This makes adaptation on the selected site difficult.

Huge discrepancies appear between the planning documents and the actual living conditions of most of the migrants. The resultant mobility of resettlers highlights the duality of the state. As Migdal writes,

States have become a formidable presence in their societies, but many have experienced faltering efforts to get their populations to do what state policy makers want them to do. States are like big rocks thrown into small ponds: they make waves from end to end, but they rarely catch any fish (Migdal 1988, 9).

The Tajik state penetrates the daily life of citizens with residence rules and control over utility and land provision, but it is unable to enforce and implement resettlement policy.

Resettlers exhibit a range of responses to their living conditions at their new places of residence. While some choose to wait for the state to live up to its promises, others take the situation into their own hands. Through this range of responses, resettlers demonstrate their ability to reshape the policy process and in effect, shape the state. With their own resources and capacities for action, resettlers are not victims of state policy. A look at resettler's perceptions, opinions and responses shows that '[t]here is no one 'indigenous' or 'local' knowledge, but competing perspectives" (Goebel 1998, 284). Some resettlers endure the harsh conditions of resettlement without complaint while others dwell on promises unfulfilled. Resettler societies in Tajikistan are a complex and independent reality with its own laws and mechanisms of reaction. 


\section{CHAPTER 5}

\section{CONCLUSION}

Resettlement has resulted in a confused situation. Over a five-year period, the state moved citizens from many parts of the country to numerous different resettlement areas. This was done before and after natural disasters and according to eight resolutions. In some instances, households were moved individually, while in others, whole villages were moved together. State implementation of resettlement policy was incomplete and inconsistent, revealing low state financial and institutional capacity. State officials are a fragmented group with various understandings of the program, different information on resettlement areas and multiple attitudes towards resettlers. The state cannot be considered a unitary actor in resettlement and as such, has multiple centers of authority.

Resettlement area living conditions fail to approach those listed in the ambitious resolutions governing resettlement, and those expected by resettlers. In response, resettlers exhibited a range of reactions upon arrival in the resettlement area, demonstrating that they are also not unitary actors. While some resettlers are state dependent and comply with resettlement conditions, others are independent agents defining the conditions of resettlement for themselves. International actors are also major players here. They responded differently to government requests for assistance simultaneously promoting and relieving low food security, showing that there are several international communities in Tajikistan. 
This seemingly straightforward plan to move people to the valleys has significantly affected citizens' livelihoods. For the most part, resettlers arrived in areas with a different climate, infertile land, a lack of irrigation and drinking water, poor housing and few employment prospects. In making this move resettlers lost important resources such as employment, social networks, acceptable housing and access to fertile land and fresh water. Their health also deteriorated due to low food security, the change in climate and poor quality of water. In effect, resettlement has undermined the livelihoods of most resettlers.

This study adds to the literature on resettlement. It confirms that migration is a complicated act and the categories 'voluntary' and 'involuntary' do not adequately capture the nature of the process. The nature of resettlement is better categorized by investigating the complexity and analyzing the aspects that give it shape. Also, in addition to the state, resettlers and international actors are active players in the state resettlement of citizens. Any study of the resettlement process must look at the roles and experiences of members of each group and expose the various motivations and reactions.

A chronological look at the resettlement process further illuminates the complexity of the situation. During the pre-resettlement phase, the state is the dominant actor. Identifying citizens who would be most interested to move, the state directs citizens in need of land as well as those living under the threat of a natural disaster to where it deems fit, the valleys. The state also determines the composition of resettlement communities since it decides which plot of land these citizens occupy. It employs statist capital and informational capital in persuading 
citizens to resettle by describing attractive living conditions in resettlement areas, which are inaccurate. Long been the only source of information, state information is accepted as truth by resettlers and state officials. State officials in all departure areas were able to attract, organize and transport citizens to the resettlement area, demonstrating high state capacity to implement this part of the policy. However the number of resettlers is seventy per cent less than outlined in the state plan, showing low state capacity to fulfill the plan.

Living in poverty, crowded housing and under the threat of a natural disaster, many citizens in Tajikistan are eager to improve their living conditions. Lacking the financial means to resettle themselves, the state offer of transport, land and financial credit is extremely attractive. Citizens without the financial means to travel to the resettlement area to see the conditions for themselves before making their decision used the information state officials gave them about the resettlement area to form their impression and expectations of the area and to make their decision on whether to resettle. This information was sometimes old and inaccurate, while other times it was current and accurate, revealing low capacity to share information among state agencies. As such, the state distributed inconsistent information, exploiting the information disadvantage of citizens.

Some potential resettlers did not rely entirely on state information to make their decision. Three whole villages that were approached by the state to resettle managed to collect funds from among their residents for several appointed leaders to travel to the state-proposed resettlement area to collect more 
information. Upon return, one group agreed to resettle to the state-proposed area while the two other groups exercised negotiating power with the state and agreed on an alternate resettlement area closer to their original place of residence. In this case financial capacity leads to negotiating power and a more desirable outcome for resettlers.

The state was able to secure citizens' agreement to resettle for several reasons. Understanding the current living conditions of the citizenry, the state designed a program that potential resettlers would find hard to refuse and that would allow it to achieve its objectives of boosting the cotton industry and securing the borders. Citizens were familiar with resettlement as a policy since the state enacted such policies during Soviet times. The state also employed deception and coercion as state officials presented inaccurate information about resettlement areas, threatened to neglect those who decided to stay at their original place of residence instead of resettling and offered assistance to vulnerable victims of natural disasters only in resettlement areas. Realizing that citizens depend on the state for information and that international actors are present in Tajikistan on the invitation of the Tajik state, the state was able to successfully deceive resettlers about living conditions in resettlement areas and direct the location of international assistance provision.

The dynamics between the state, resettlers and international actors change during the post-resettlement phase. Although able to assert control in the pre-resettlement phase, the state loses control of citizens and policy implementation in resettlement areas in the post-resettlement phase. The state 
failed to provide the infrastructure and compensation outtined in the resolutions governing resettlement. It also failed to resettle the number of citizens called for in the resettlement plan and to enforce the rules of resettlement. The state is also unable to keep resettlers in the resettlement area. The state therefore lacks any meaningful influence over resettlers after resettlement. With no mechanisms in place to check state accountability, the state is not reprimanded for poor implementation of the resettlement policy. Acknowledging poor living conditions in resettlement areas and low state capacity, the state appeals to international organizations to compensate with aid to resettlers.

The decision of international organizations to provide aid in resettlement areas affects state and resettler capacity. International actors exhibited different motivations for providing and not providing assistance. Those that provided aid did so because of resettler need and government requests, while those that did not provide assistance did so based on instructions from their head offices and on unconfirmed perceptions of unacceptable government motives for resettlement. The provision of aid by international organizations amounts to indirect support of resettlement policy since it keeps resettlers in the resettlement areas as potential if not actual cotton pickers. In effect, this assistance shifts state capacity from low towards high, whereas their refusal to provide aid is equivalent to disagreement with state policy and keeps state capacity low. In providing aid, international organizations also improve the capacity of resettlers since their assistance improves food security, health and education. Overall, international organizations affect resettler capacity more than state capacity. 
Their aid directly improves the lives of resettlers and although it may keep some resettlers at their new home and in this way affect state capacity, many other resettlers are nonetheless leaving which shifts state capacity back towards low.

Resettlers affect implementation of resettlement policy most directly. With low state capacity to enforce the rules of resettlement, resettlers are able to decide their own compliance with resettlement. The inhospitable living conditions in resettlement areas triggered a variety of responses from the resettled population. Although their experiences of resettlement are highly differentiated, common to all resettlers is that survival is the main motivation in pursuing their strategy of choice.

Many resettlers abide by the rules and conditions of resettlement. Some do this because they can imagine no alternative to the state as their provider. The state has disciplined the minds of these resettlers by shaping their expectations, knowledge and influences, and has disciplined their bodies through residence rules, diverting them to employment in the cotton sector and by limiting their agricultural productivity. Other resettlers fail to have or acquire the skills to improve their situation. Unable to improve the fertility of their land and unaware of their rights as migrants, these resettlers depend on the state to improve their situation. Without the financial means to leave, these resettlers are confined to the resettlement area.

Many other resettlers practice forms of "everyday resistance". While some resettlers maintain two residences, one in the resettlement area and one at their previous place of residence, others have permanently returned to their previous 
place of residence or moved to other areas in Tajikistan or to Russia. Labour migration to Russia is financing further flight of resettlers in the same directions. The 'settling' process is undermined by this further migration because the state is unable to enforce the residence rule. Those that flee remain on the residence register in the resettlement area, securing themselves humanitarian aid if and when it arrives. This is evidence of evasion and deception, other forms of "everyday resistance". Therefore these resettlers emerge as dominant actors determining the course of state policy implementation because of weak state institutional capacity. State officials acknowledge resettlers are leaving resettlement areas and although their departure has not halted state resettlement plans, it has influenced both plan fulfillment and discussions of future resettlement plans.

Resettlers' resistance to complying with the conditions of resettlement laid down by the state was ultimately a result of the state failure to provide the living conditions it reported existed at resettlement sites. They were able to exercise non-compliance for several additional reasons. They arrived without the skills needed to improve their life in the resettlement area, they lost faith in the state, they were able to negotiate financial loans with their neighbours and the state failed to pay those working in cotton what they deserve so they chose to search for work elsewhere. Resettlers are powerful actors after resettlement with the capacity to interpret what the rules mean and elaborate their own strategies of survival. With this capacity they are able to shape the policy implementation process in Tajikistan. 
This chronological look at the roles and actions of the state, resettlers and representatives of international organizations in resettlement is telling. The Tajik state asserts control before resettlement, only to lose it after resettlement due to low state financial and institutional capacity. The state is a dynamic mix of its Soviet past and globalized, international present. Contemporary resettlement is a repeat of the Soviet modernization project in a post-war setting. The Tajik state's reliance on cotton production is a mechanism for social control as during Soviet times, but now exports are a significant source of revenue for the independent state. The state finds financial capacity in reproducing Soviet structures and practices. However, there is an absence of any state attempt to implement alternative solutions even when resettlement is clearly overall causing more harm than good for the people concerned and international actors and low state capacity. Like resettlers, the state has the goal of survival, but it also strives for regional and international integration. Post-Soviet Tajikistan is an actor in its own right, though it relies on good relations with international actors and the compliance of citizens to survive due to its weak financial and institutional capacity.

Citizens are both agents and subjects in Tajikistan. Despite losing social networks and access to valuable resources upon resettlement, some resettlers are able to exercise power to improve their situation. These resettlers are not victims of state resettlement policy since they realize holding the state accountable for its promises is futile and employ resources and capacities for action such as knowledge, technical skills, finance and initiative. Resettler 
agency shows there are limits to state power in Tajikistan and that resettlers live in an independent reality with their own laws. Other resettlers comply with the conditions of resettlement since they lack these same capacities and because the turmoil of resettlement leads to the continuance of already established roles.

An analysis of the influence of international organizations on governance in Tajikistan must go beyond reporting the mere presence of international organizations and look at the type and substance of their participation. There are multiple international communities in Tajikistan with various motivations and outlooks. Some international organizations were instrumental to the exercise of state power, while others tried to block it. Some were aiming to change state institutions and practices, while others were aiming to improve the lives of citizens. International actors tried to shape the decisions of the state, as well as citizens. The agency and power of international actors to influence state policy is questionable since the state is continuing with resettlement despite the concerns of some international actors. However, these concerns were never communicated to the government in a formal manner which may have influenced the government. Although international actors are excluded from the policy making process, they indirectly affect this process through aid provision. The provision of food aid to resettlers allows the Tajik government to turn its focus away from resettlers and towards cotton production.

The state, resettlers and international organizations have an interdependent relationship, but the motivations of each group are different. The state aims to improve the economy and maintain Tajikistan's sovereignty, 
resettlers are focused on issues of basic subsistence and international organizations are working both to improve state institutional capacity and the life of citizens. With a low financial and institutional capacity, the state depends on international organizations to perform state tasks, such as feeding the citizenry. International organizations rely on the state to endorse their activities. The assistance or non-assistance international organizations render plays on their relations with the state, as well as citizens' living conditions and the state's ability to implement policy. The state depends on resettlers to pick cotton and to safeguard the borders of the state. Resettlers rely on the state for land, water and electricity, which is under state control. Having realized the low capacity of the state, resettlers appeal to international organizations for aid, as does the Tajik state, to compensate for the state's unfulfilled promises.

Even though these players are interdependent, they are autonomous from each other. The state can exercise the power to remove international organizations from the country. International organizations are ultimately beholden to the interests of their external donor(s) and as such, aid provision depends on these interests, not on the Tajik state or resettlers. With low state institutional capacity, resettlers are able to articulate their autonomy from the state by leaving the resettlement area. Resettlers and state officials each have their turn to act as the dominant actor during the resettlement process, while international actors always play a complementary role to members of both groups. 
As the roles of each player are shifted around, the "strong-weak" state balance tilts towards "strong" or "weak", at times losing strength and at others gaining strength. Although each player has its own separate motivations and logic, they all influence each other. In effect, resettlers, state officials and representatives of international organizations are mutually constitutive of each other. Therefore, as Erika Weinthal found in other Central Asian states, the state's ability to implement policies is not just a function of state-society interactions, but also a function of state-international actor relations and societyinternational actor relations (Weinthal 2004, 252).

This interdependent relationship between the state, resettlers and international organizations indicates that resettlement is a non-linear, dynamic process. We must consider the interactions of all players and their different motivations over the course of time in the analysis. The actions of each player do not take place in a vacuum; they affect members of their own group as well as the other groups. The situation is in flux, it is not static and not necessarily approaching one final destination. The players are not always opposed, separate and timeless entities. They act to both undermine and enforce the process as well as the actions of each other, all the while revealing power as a dispersed and decentralized phenomenon.

The balance in this relationship depends on the actions and non-actions of each player within each group. As such there is no single categorization of state capacity here. It shifts depending on the particular circumstances and players. It is in continuous flux. There is no one group that ultimately determines the 
survival of both the other groups. The Tajik state and international actors are dependent on each other for their existence, but resettlers are able to act as agents without the help of either the state or international actors. As such the interdependent relationship is sustainable. However, should resettlers lose their capacity for agency and become entirely dependent on the state and international actors as a group, the interdependent relationship would turn fragile, with each group depending on the others for survival.

The result of resettlement is a confused and complex Tajik society, in which all three groups play major roles. This study exposed the disparity that can exist between policy design and implementation. In this case, policy design was ambitious considering the low financial commitment of the state for resettlement. With limited state influence on society, resettlers seized the opportunity to respond to their situation in various ways. International actors and state officials also respond to resettlement in different ways. The multiple interests and reactions of those involved renders resettlement a dynamic process that changes over time and exposes the shifting balance that characterizes the contemporary, post-Soviet Tajik state. 


\section{BIBLIOGRAPHY}

Abdullaev, Kamoludin and Shahram Akbarzadeh. 2002. Historical Dictionary of Tajikistan. Lanham, Maryland: Scarecrow Press.

Abdullaev, Sheroz, Aga Khan Representative (Khorog). 2004. Interview by author, 29 October, Khorog. Written Recording. Carleton University, Ottawa.

Abdullaev, Zafar and Kambiz Arman. 2005. Eurasia Net. 28 February. Internet. Available from http:www.eurasianet.org/departments/insight/articles/eav022805b.shtm; accessed 13 June 2005.

Abdullo, Ziyo and Jonibek Akobir. 2002. The First Meeting. Sulhi Osiyo, 7 September, 12. (In Russian)

Abel, Genevieve, Director CARE (Dushanbe). 2004. Interview by author, 7 September, Dushanbe. Tape Recording. Carleton University, Ottawa.

Abootalebi, Ali Reza. 2000. Islam and Democracy. New York: Garland Publishing Inc.

Adams, Laura. 2004. Cultural Elites in Uzbekistan: Ideological Production and the State. In The Transformation of Central Asia, ed. Pauline Jones Luong, 93119. Ithaca: Cornell University Press.

Akcali, Pinar. 2003. Nation-State Building in Central Asia: A Lost Case? Perspectives on Global Development and Technology 2 (3-4): 409-429.

Akiner, Shirin. 2002. Prospects for Civil Society in Tajikistan. In Civil Society in the Muslim World, ed. Amyn B. Sajoo, 149-193. New York: Routledge.

Aljazeera Network. 2005. Tajik Islamic Party Slams Hijab Ban. 1 November. Internet. Available from: http://english.aljazeera.net/NR/exeres/6AA44AAC87AD-4DA2-89C0-2D324F99C033.htm; accessed 1 November 2005.

Arendt, Hannah. 1970. On Violence. London: Allen Lane.

Asia Plus (Dushanbe, Tajikistan). 2005. Formation of Russian Military Base in Tajikistan Practically Completed, Says Russian Ambassador. 24 October. Internet. Available from http://www.asiaplus.ti/eng/index.php; accessed 24 October 2005. Russian).

2002a. Suffering Pamiris Being Sent to Beshkent. 15 August. (In 
. 2002b. Resettlers from GBAO in Critical Situation. 30 May. (In Russian).

Atkin, Muriel. 2002. Tajikistan: A President and His Rivals. In Power and Change in Central Asia, ed. Sally N. Cummings, 97-114. New York: Routledge.

1997. Thwarted Democratization in Tajikistan. In Conflict, Cleavage and Change in Central Asia and the Caucasus, ed. Karen Dawisha and Bruce Parrott, 277-311. New York: Cambridge University Press.

Avazlieva, Oidinoi, State Migration Services Official (Shaartuz). 2004. Interview by author, 6 October. Tape Recording. Carleton University, Ottawa.

Avesta (Dushanbe, Tajikistan). 2005. New Tajik-Afghan Bridge Marks New Era of Geopolitical Change. 30 June. (In Russian).

Azizmamadova, Shirin. 2005. Uzbeks Clear Mines from Tajik Border. 30 October. Institute for War and Peace Reporting. Internet. Available from

http://www.iwpr.net/index.pl?archive/rca2/rca2_417_4_eng.txt; accessed 31

October 2005.

Bakhtiyor, Khalilov, Agriculture Assistant of CARE. 2004. On Travel to Qumsangir and Nosiri Khisrav Districts. To Nasimova Firuza, Project Manager, CARE. 2 July. CARE, Dushanbe, Tajikistan.

Barakat, Sultan and Arne Strand. 2000. Forced Migration and Dilemmas of Humanitarian Assistance: Challenges for Applied Research. Norwegian Journal of Geography (54): 134-136.

Barkey, Karen and Sunita Parikh. 1991. Comparative Perspectives on the State. Annual Review of Sociology 17: 523-549.

Barotov, Odina, State Migration Services Official (Beshkent). 2004. Interview by author, 6 October, Shaartuz. Tape Recording. Carleton University, Ottawa.

Barr, Abigail. 2004. Forging Effective New Communities: The Evolution of Civil Society in Zimbabwean Resettlement Villages. World Development 32 (10): 1753-1766.

Berdahl, Daphne. 1999. Where the World Ended: Reunification and Identity in the German Borderland. Berkley, CA: University of California Press.

Beshkent 1. 2004. Interview by author, 21 October, Beshkent 1. Tape Recording. Carleton University, Ottawa. 
Beshkent 2 Group 1. 2004. Interview by author, 5 October, Beshkent 2. Tape Recording. Carleton University, Ottawa.

Beshkent 2 Group 2. 2004. Interview by author, 21 October, Beshkent 2. Tape Recording. Carleton University, Ottawa.

Boboev, Anvar, Minister of State Migration Services. 2004. Interview by author, 27 August, Dushanbe. Tape Recording Carleton University, Ottawa.

Bohr, Annette. 2004. Regionalism in Central Asia: New Geopolitics, Old Regional Order. International Affairs 80 (3): 485-502.

Bosc, Igor, Head of Mission International Organization for Migration. 2004. Interview by author, 2 September, Dushanbe. Tape Recording. Carleton University, Ottawa.

Bourdieu, Pierre. 1977. The Economics of Linguistic Exchanges. Social Science Information 16(6): 654-68.

British Broadcasting Corporation (BBC). 2005a. Ian MacWilliam. Tajik Opposition Leader Jailed. 5 October. Internet. Available from: http://news.bbc.co.uk/go/pr/fr//1/hi/world/asia-pacific/4312466.stm; accessed 5 October 2005.

. 2005b. Country Profile: Tajikistan. 30 August. Internet. Available from http://news.bbc.co.uk/1/hi/world/asia-pacific/country_profiles/1296639.stm; accessed 12 September 2005.

2005c. Russian Border Troops Fear Greater Afghan Drug Flow After Tajik Pullout. 22 March (Lexis Nexis).

2002. Another 100 Tajik Families to be Resettled in South from Eastern Region. 17 April (Factiva).

Buse, Kent. 1999. Keeping a Tight Grip on the Reins: Donor Control Over Aid Coordination and Management in Bangladesh. Health Policy and Planning 14(3): 219-228.

Burniske, Gary, Director of Mercy Corps (Dushanbe). 2004. Interview by author, 14 September, Dushanbe. Tape Recording. Carleton University, Ottawa.

Buszynski, Leszek. 2005. Russia's New Role in Central Asia. Asian Survey 45 (July/August): 546-565.

Capisani, Giampaolo R. 2000. The Handbook of Central Asia. New York: St. Martin's Press. 
CARE. 2002. Terms of Reference: Integrated Resettlement Assessment.

Carey, Henry F. and Rafal Raciborski. 2004. Postcolonialism: A Valid Paradigm for the Former Sovietized States and Yugoslavia? East European Politics and Societies 18 (2): 191-235.

Cernea, Michael. 1999. The Economics of Involuntary Resettlement: Questions and Challenges. Washington, DC: World Bank.

. 1997. The Risks and Reconstruction Model for Resettling Displaced Populations. World Development 25 (1): 1569-1587.

Chapaev Group, Resettlers. 2004. Interview by author, 2 November, Chapaev. Written Recording. Carleton University, Ottawa.

Charkhi Gardun (Dushanbe, Tajikistan). 2002. Badakhshanis are being Resettled to Beshkent, 30 August, 2. (In Tajik).

Chashma Group. 2004. Interview by author, 21 October, Chashma. Tape Recording. Carleton University, Ottawa.

Cheterian, Vicken. 2005. Torn Between Nationalists and Islamists Central Asia's Five Fragile States. Le Monde Diplomatique. March. Internet. Available from http://www.cimera.org/en/about/LeMondediplomatique-March2005.doc; accessed 19 October 2005.

Chorshanbieva, Natalya. 2004. Interview by author, 6 October, Navruz. Tape Recording. Carleton University, Ottawa.

Chortimur Group, Resettlers. 2004. Interview by author, 4 November, Chortimur. Written Recording. Carleton University, Ottawa.

Chudoba, Johannes, Director of United Nations Office for Coordination of Humanitarian Affairs. 2004. Interview by author, 30 August, Dushanbe. Tape Recording. Carleton University, Ottawa.

Cokgezen, Murat. 2004. Corruption in Kyrgyzstan: The Facts, Causes and Consequences. Central Asian Survey 23 (1): 79-94.

Colson, Elizabeth. 2003. Forced Migration and the Anthropological Response. Journal of Refugee Studies 16 (1): 1-18.

Cummings, Sally N. 2002. Introduction: Power and Change in Central Asia. In Power and Change in Central Asia, ed. Sally N. Cummings, 1-24. New York: Routledge. 
Dadabaev, Timur. 2004. Post-Soviet Realities of Society in Uzbekistan. Central Asian Survey June 2004 23(2): 141-166.

Dashti Kozi Group. 2004. Interview by author, 25 September, Dashti Kozi. Tape Recording. Carleton University, Ottawa.

Dave, Bhavna. 2004. A Shrinking Reach of the State? Language Policy and Implementation in Kazakhstan and Kyrgyzstan. In The Transformation of Central Asia, ed. Pauline Jones Luong, 120-158. Ithaca: Cornell University Press. Davlatov, Sharif, State Migration Services Official (Dushanbe). 2004. Interview by author, 16 November. Written Recording. Carleton University, Ottawa.

Dikayev, Turko. 2005a. Some 1000 Families from Khatlon Province to Be Moved to Tursunzoda District. 9 August. Asia Plus (Dushanbe). (Factiva).

.2005b. Celebration of $2700^{\text {th }}$ Anniversary of Kulob Scheduled for 2006. 28 April. Asia Plus (Dushanbe). (Factiva)

Eurasia Net. 2005a. Uzbek Government Exerting Pressure on Local NGOs to Close 'Voluntarily'. 4 October. Internet. Available from http://www.eurasianet.org/departments/civilsociety/articles/eav100405 pr.shtml; accessed 5 October 2005

Available from

2005b. Opposition Under Pressure in Tajikistan. 19 September. Internet. http://www.eurasianet.org/departments/insight/articles/eav091905aru_pr.shtml; accessed 19 September 2005

. 2003. Tajikistan Conference Draws Attention to Lack of Central Asian Cooperation on Water Issues. 2 September. Internet. Available from: http://www.eurasianet.org/departments/environment/articles/eav090203.shtml; accessed 19 July 2005.

European Union (EU). 2005a. Overview of BOMCA. 17 March . Internet. Available from http://www.eu-bomca.org/en/fareas/overview; accessed 2 October 2005.

.2005b. US, EU to help Tajiks police Afghan border, as Russia pulls out. 16 February. Available from: http://www.eubusiness.com/afp/050216165242.10awpkm4; accessed on 11 July 2005.

2004. Strategy of BOMCA. 24 February. Internet. Available from http://www.eu-bomca.org/en/about/strategy; accessed 2 October 2005. 
. 2002. Strategy Paper 2002-2006 and Indicative Program 2002-2004 for Central Asia. 30 October. Internet. Available from http://europa.eu.int/comm/external_relations/ceeca/rsp2/02_06_en.pdf; accessed 2 January 2006.

Evrard, Olivier and Yves Goudineau. 2004. Planned Resettlement, Unexpected Migrations and Cultural Trauma in Laos. Development and Change 35 (5): $937-$ 962.

Fairfield, Paul. 2002. The Ways of Power. Pittsburgh, PA: Duquesne University Press.

Feerasta, Hakim, Director Aga Khan Development Network (Dushanbe). 2004. Interview by author, 2 September, Dushanbe. Tape Recording. Carleton University, Ottawa.

Freizer, Sabine. 2004. Central Asian Fragmented Civil Society: Communal and Neoliberal Forms in Tajikistan and Uzbekistan. In Exploring Civil Society: Political and Cultural Contexts, ed. Marlies Glasius, David Lewis and Hakan Seckinelgin, 130-140. New York: Routledge.

Gamble, Greg, Director of Global Partners (Dushanbe). 2004. Interview by author, 31 August, Dushanbe. Tape Recording. Carleton University, Ottawa.

Gebre, Yntiso D. 2002. Contextual Determination of Migration Behaviours: The Ethiopian Resettlement in Light of Conceptual Constructs. Journal of Refugee Studies, Vol. 15, No. 3, 265-282.

Glenn, John. 1999. The Soviet Legacy in Central Asia. New York: Palgrave.

Global IDP Project. 2005a. Turkmenistan: Government Uses Forced Displacement as Tool of Repression. Internet. Available from http://www.internaldisplacement.org/8025708F004BE3B1/(httpInfoFiles)/445B7E4296658EC18025 70B5004D2925/\$file/Turkmenistan_summary.pdf; accessed 18 October 2005.

. 2005b. Uzbekistan: Authorities Deny Return of Thousand Villagers Displaced from Tajik Border. Internet. Available from http://www.internaldisplacement.org/8025708F004BE3B1/(httpInfoFiles)/5C60AF56D125FADCC12 570CA003B4C43/\$file/Uzbekistan_overview_oct05.pdf; accessed 18 October 2005.

Goebel, Allison. 1998. Process, Perception and Power: Notes from 'Participatory' Research in a Zimbabwean Resettlement Area. Development and Change 29: 277-305. 
Grzymala-Busse, Anna and Pauline Jones Luong. 2002. Reconceptualizing the State: Lessons from Post-Communism. Politics and Society 30 (December): 529-554.

Guillemot, Joy, Director of MERLIN. 2004. Interview by author, 28 August, Dushanbe. Written Recording. Carleton University, Ottawa.

Habart, Helisene, Project Manager European Commission (Dushanbe). 2004. Interview by author, 14 September, Dushanbe. Written Recording. Carleton University, Ottawa.

Hall, Michael, Director of International Crisis Group (Dushanbe). 2004. Interview by author, 15 September, Dushanbe. Written Recording. Carleton University, Ottawa.

Hann, Chris. 1996. Introduction: Political Society and Civil Anthropology. In Civil Society: Challenging Western Models, ed. Chris Hann and Elizabeth Dunn, 1-26. New York: Routledge.

Harris, Collette. 2004. Control and Subversion: Gender Relations in Tajikistan. Sterling, Virginia: Pluto Press.

Hasson, S. and N. Gosenfeld. 1980. Israeli Frontier Settlements: a CrossTemporal Analysis. Geoforum 11: 315-334.

Haugaard, Mark. 2003. Relections on Seven Ways of Creating Power. European Journal of Social Theory 6(1): 87-113.

ed. 2002. Power: A Reader. New York: Manchester University Press.

Hofecker, Glen, Director Global Partners (Khorog). 2004. Interview by author, 28 October, Khorog. Written Recording. Carleton University, Ottawa.

Horsman, Stuart. 1999. Uzbekistan's Involvement in the Tajik Civil War 1992-97: Domestic Considerations. Central Asian Survey 18 (1): 37-48.

Human Rights Watch. 2005. Country Summary: Tajikistan. January. Internet. Available from: http://hrw.org/english/docs/2005/01/13/tajiki9897_txt.htm; accessed 4 August 2005.

2004. Country Summary: Tajikistan. January. Internet. Available from:

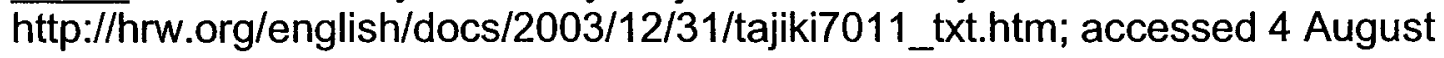
2005.

2003. Country Summary: Tajikistan. January. Internet. Available from: http://www.hrw.org/wr2k3/europe12.html; accessed 24 October 2005. 
lji, Tetsuro. 2005. Cooperation, Coordination and Complementarity in International Peacemaking: The Tajikistan Experience. International Peacekeeping 12 (2) Summer: 189-204.

Indra, Doreen, ed. 1990. Engendering Forced Migration: Theory and Practice. New York: Berghahn.

Institute of War and Peace Reporting (London). 2005a. Iran Looks to Strengthen Tajik Ties. 30 August. Internet. Available from:

http://www.iwpr.net/index.pl?archive/rca2/rca2_407_2_eng.txt; accessed 1 September 2005.

. 2005b. Water Problems in Tajikistan. 12 August. Internet. Available from http://www.iwpr.net/index.pl?archive/rca2/rca2_402_4_eng.txt; accessed 1 Sept. 2005.

Interfax. 2005. French Military Presence in Tajikistan Depends on Bilateral Accords - Envoy. 7 July. (Lexis Nexis).

International Crisis Group. 2005. The Curse of Cotton: Central Asia's Destructive Monoculture. 28 February. Internet. Available from:

http://www.crisisgroup.org/home/index.cfm?id=3294\&l=1; accessed 30 April 2005.

2004. Tajikistan's Politics: Confrontation or Consolidation? 19 May. Internet. Available from http://www.crisisgroup.org/home/index.cfm?id=2757\&l=1; accessed 30 December 2005.

2003a. Central Asia: Islam and the State. 10 July Internet. Available from http://www.crisisgroup.org/home/index.cfm?id=1442\&l=1; accessed 4 September 2005.

2003b. Radical Islam in Central Asia: Responding to Hizb ut-Tahrir. 30 June. Internet. Available from http://www.crisisgroup.org/home/index.cfm?id=1441\&l=1; accessed 10 October 2005.

International Federation of the Red Cross (IFRC). 2002. Tajikistan: Landslide Information Bulletin No. 03/2002. Internet. Available from http://www.reliefweb.int/w/rwb.nsf/0/84636c7a2bbeff8fc1256c2200536314?Open Document; accessed 11 May 2004.

International Organization for Migration. 2005. Children in the Cotton Fields. Dushanbe: privately printed. 
2004. Glossary on Migration. International Organization for Migration: Geneva, Switzerland. 2003. Labour Migration From Tajikistan. Dushanbe: privately printed.

ITAR-TASS. 2005. Russia-Tajik Border Guard Cooperation Needs BoostRakhmonov. 8 September (World News Connection)

Jackson, S and A. Sleigh. 2000. Resettlement for China's Three Gorges Dam: Socio-Economic Impact and Institutional Tensions. Communist and PostCommunist Studies 33(June): 223-241.

Jacobsen, Karen and Loren B. Landau. 2003. The Dual Imperative in Refugee Research: Some Methodological and Ethical Considerations in Social Science Research on Forced Migration. Disasters 27 (3): 185-206.

Jones Luong, Pauline. 2004a. Central Asia's Contribution to Theories of the State. In The Transformation of Central Asia, ed. Pauline Jones Luong, 29-58. Ithaca: Cornell University Press.

. 2004b. Economic "Decentralization" in Kazakhstan: Causes and Consequences In The Transformation of Central Asia, ed. Pauline Jones Luong, 182-210. Ithaca: Cornell University Press.

. 2004c. Introduction. In The Transformation of Central Asia, ed. Pauline Jones Luong, 1-28. Ithaca: Cornell University Press. . 2002. Institutional Change and Political Continuity in Post-Soviet Central Asia. New York: Cambridge University Press.

Kadamshoi, Sarvar, State Migration Services Official (Rushan). 2004. Interview by author, 17 August, Rushan. Written Recording. Carleton University, Ottawa.

Kamp, Marianne. 2004. Between Women and the State. In The Transformation of Central Asia, ed. Pauline Jones Luong, 29-58. Ithaca: Cornell University Press.

Karadum Group, Resettlers. 2004. Interview by author, 22 October, Karadum. Written Recording. Carleton University, Ottawa.

Karimova, Makhfirat, State Migration Services Official (Kulyab). 2004. Interview by author, 12 October, Kulyab. Tape Recording. Carleton University, Ottawa.

Kasymbekova, Valentina. 2005. Tajikistan: Hard Life for Rural Women. Institute of War and Peace Reporting (London). 25 August. Internet. Available from: 
http://www.iwpr.net/index.pl?archive/wp/wp_008_02_eng.txt; accessed on 27 September 2005.

Katada, Saori N. 2001. Why did Japan Suspend Foreign Aid to China? Japan's Foreign Aid Decision-Making and Sources of Sanction. Social Science Japan Journal 4 (1): 39-58.

Khairuddinov, Boris and Zafar Abdullaev. 2004. Tajikistan: Dreaming of the Mountains. Institute of War and Peace Reporting (London). Internet. Available from http://www.iwpr.net/index.pl?archive/rca/rca_200405_286_4_eng.txt; accessed 8 September 2004.

Khassanov, Sukhrob. 2004. Interview by author, 24 September, Penjikent. Tape Recording. Carleton University, Ottawa.

Khodeiberdiev, Khodeiberdi, Ministry of Emergency Situations Official (Khujand). 2004. Interview by author, 22 September, Khujand. Written Recording. Carleton University, Ottawa.

Kinsey, B.H. 1982. Forever Gained: Resettlement and Land Policy in the Context of National Development in Zimbabwe. Africa: Journal of the International African Institute 52 (3): 92-113.

Kondrashova, Valentina. 2005. Damage Caused by Natural Disasters to Tajikistan this Year Amounts to Over 200 Million Somonis. Asia Plus (Dushanbe, Tajikistan) 11 October. (In Russian).

Kreutzmann, Hermann. 2003. Ethnic Minorities and Marginality in the Pamirian Knot: Survival of Wakhi and Kirghiz in a Harsh Environment and Global Contexts. The Geographical Journal 169 (3): 215-235.

Kudratov, Faizullo, Project Manager Oxfam (Kulyab). 2004. Interview by author, 11 October, Kulyab. Written Recording. Carleton University, Ottawa.

Kurbanova, S.I. 1993. Resettlement: How it Was. Dushanbe: Irfon. (In Russian).

Latifov, Yuri, State Migration Services Official (Dushanbe). 2004. Interview by author, 1 December, Dushanbe. Written Recording. Carleton University, Ottawa.

Lehrer, David and Anna Korhonen. 2004. Postcommunist Aid Negotiation: A Review of Recent Research. Cambridge Review of International Affairs 17 (3): 593-616.

Lichbekov, Zuribek, Local Government Representative (Roshtkala). 2004. Interview by author, 29 October, Roshtkala. Written Recording. Carleton University, Ottawa. 
Lieber, Michael D. 1977. Conclusion: The Resettled Community and Its Context. In Exiles and Migrants in Oceania, ed. Michael D. Lieber, 385-399. Honolulu: The University Press of Hawaii.

Lukes, Steven. 2005. Power and the Battle for Hearts and Minds. Millennium: Journal of International Studies 33(3): 477-493.

MacFarlane, N. 1999. Western Engagement in the Caucasus and Central Asia. Central Asian and Caucasian Prospects Project. London: Royal Institute of International Affairs.

Makhmadshoev, Farukh, Project Manager United Nations World Food Programme. 2004. Interview by author, 6 September, Dushanbe. Tape Recording. Carleton University, Ottawa.

Mamadjanova, Mehrinisso. 2004. Interview by author, 7 October, Dakhana. Tape Recording. Carleton University, Ottawa.

Mamadev, Farukh. 2004. Interview by the author, 6 September, Dushanbe.

Mamadshoev, Marat. 2004. History of the Appearance of the Propiska. Asia Plus (Dushanbe, Tajikistan), 19 February. Internet. Available from http://www.asiapluc.tj/arkhiv/2004/24.htm; accessed 24 October 2005. (In Russian)

2002a. White Sun of Beshkent 2. Asia Plus (Dushanbe, Taiikistan), 4

July, 3. (In Russian)

. 2002b. Tajikistan: Down and Out in Beshkent. Institute of War and Peace Reporting (London), 18 June. Internet. Available from http://www.iwpr.net/? $p=r c a \& s=f \& o=175340 \& a p c \_s t a t e=h e n i r c a 2002 ;$ accessed 11 May 2004.

Mannonov, Bahrom. 2005. Tajik President Urges to Fulfill Resolutions Adopted at SCO Summit in Astana. Asia Plus (Dushanbe, Tajikistan). 8 July (Factiva)

Massiiwa, Medicine. 2005. The Fast Track Resettlement Programme in Zimbabwe: Disparity Between Policy Design and Implementation. The Round Table 94 (379): 217-224.

Matthews, Sally. 2004. Post-Development Theory and the Question of Alternatives: A View from Africa. Third World Quarterly, 25(2): 373-384.

McDermott, Roger. 2005a. Tajikistan Searches for Border Security Assistance. Eurasia Daily Monitor (Washington, DC). 12 October. Internet. Available from: 
http://www.jamestown.org/print_friendly.php?volume_id=407\&issue_id=3489\&arti cle_id=2370329; accessed 11 November 2005.

2005b. Tajikistan's Border Service Plagued by Corruption. Eurasia Daily Monitor (Washington, DC). 9 August. Internet. Available from: http://www.jamestown.org/authors_details.php?author_id=174 accessed 10 August 2005.

McGrath, Michael, Director of Save the Children USA. 2004. Interview by author, 31 August, Dushanbe. Tape Recording. Carleton University, Ottawa.

McMann, Kelly. 2004. The Civic Realm in Kyrgyzstan: Soviet Economic Legacies and Activists' Expectations. In The Transformation of Central Asia, ed. Pauline Jones Luong, 213-245. Ithaca: Cornell University Press.

Meikle, Sheila and Julian Walker. 2000. The Theory and Practice of Resettlement in China. Eastern Anthropologist 53 (1-2): 35-49.

Merry, E. Wayne. 2004. Governance in Central Asia: National in Form, Soviet in Content. Cambridge Review of International Affairs 17 (July): 285-300.

Migdal, Joel. 1988. Strong Societies and Weak States. Princeton, New Jersey: Princeton University Press.

Mitchell, 1999. Society, Economy and the State Effect. In State/Culture: State Formation after the Cultural Turn, ed. George Steinmetz, 76-97. Cornell University Press, Ithaca New York.

Mizrab, Sayyof. 2004. Golden Beshkent or a Trap for the Poor? Olamu Odam (Dushanbe, Tajikistan), 5 August. (In Russian).

Muggah, Robert. 2003. A Tale of Two Solitudes: Comparing Conflict and Development-Induced Internal Displacement and Involuntary Resettlement. International Migration 41 (5): 5-27.

Muroteppa Group, Resettlers. 2004. Interview by author, 21 October, Muroteppa. Tape Recording. Carleton University, Ottawa.

Nakayama, Mikiyasu, et al. 1999. Resettlement Issues of Cirata Dam Project: A Post-project Review. Water Resources Development 15 (December): 443-458.

Nazarov, Nazar. 2005a. Tajikistan: Government Resorts to Repression and Intimidation. Eurasia Net. 29 April. Internet. Available from http://www.eurasianet.org/departments/insight/articles/eav042905.shtml; accessed 13 June 2005. 
2005b. Tajik Opposition Leader Arrested. Institute for War and Peace Reporting (London). 29 April. Internet. Available from http://www.iwpr.net/index.pl?archive/rca2/rca2_372_2_eng.txt; accessed 12 September 2005.

Nazarov, Timur and Tadjiniso Nosirova. N.d. The Beshkent Valley. Available from: http://enrin.grida.no/story.cfm?article=16; accessed 19 October 2004.

Nazirov, Sairakhmon. 2005. Hostages of Beshkent. Asia Plus (Dushanbe, Tajikistan), 10 November. Internet. Available from http://www.asiaplus.tj/article/weeknews.htm; accessed 12 November 2005.

Nourzhanov, Kirill. 2005. Saviours of the Nation or Robber Barons? Warlord Politics in Tajikistan. Central Asian Survey 24 (June): 109-130.

Nurov, Mamadsaid, Potential Resettler. 2004. Interview by author, 28 October, Ishkashim. Written Recording. Carleton University, Ottawa.

Nye, Joseph S. 2004. Soft Power: The Means to Succeed in World Politics. New York: Public Affairs.

Olimov, Shamsi, State Migration Services Official (Varzob). 2004. Interview by author, 7 December. Written Recording. Carleton University, Ottawa.

Oliver-Smith, A. 1991. Involuntary Resettlement: Resistance and Political Empowerment. Journal of Refugee Studies 4 (2): 132-149.

Olsen, Gorm Rye, Nils Carstensen and Kristian Hoyen. 2003. Humanitarian Crises: What Determines the Level of Emergency Assistance? Media Coverage, Donor Interests and the Aid Business. Disasters 27(2): 109-126.

Overland, Indra. 2005. "Humanitarian Organizations in Tajikistan and the Coordination of Aid to Displaced Afghans in No Man's Land". Journal of Refugee Studies 18 (2): 133-150.

Oxfam. 2004. "Research Notes from Fieldwork in Beshkent."

Pannier, Bruce. 2005a. Central Asia: Tajiks Begin Taking Over Guard Duties from Russians on Southern Border. Eurasia Net. 17 November. Available from http://www.eurasianet.org/departments/insight/articles/pp111704a.shtml; accessed 13 June 2005.

2005b. Tajikistan: Opposition Leader Brought Home to Face Charges, Ex-Interior Minister Imprisoned for 15 Years. Radio Free Europe/Radio Liberty. 27 April. Internet. Available from 
http://www.rferl.org/featuresarticle/2005/04/e8aec502-90f6-4ce0-90f1d6f2b1a22c91.html; accessed 12 September 2005.

Peel, Quentin. 2005. Central Asia is Corrupted by Cotton. Financial Times 10 March. Available from: http://yaleglobal.yale.edu/display. article?id=5399; accessed 2 August 2005.

Pichon, Cecile, Director European Commission Humanitarian Organization (Dushanbe). 2004. Interview by author, 6 September, Dushanbe. Tape Recording. Carleton University, Ottawa.

Pirmatova, Nigina, Resettler. 2004. Interview by author, 21 October, Beshkent 1. Tape Recording. Carleton University, Ottawa.

Polian, Pavel. 2004. Against their Will: The History and Geography of Forced Migrations in the USSR. New York: Central European University Press.

Polovonov, Ikhbolkhon, Department of Labour Official (Ishkashim). 2004. Interview by author, 28 October, Ishkashim. Written Recording. Carleton University, Ottawa.

Prelics, Miklos, Director of Organization for Security and Cooperation in Europe (Shaartuz). 2004. Interview by author, 5 October, Shaartuz. Tape Recording. Carleton University, Ottawa.

Prescott, J.R.V. 1987. Political Frontiers and Boundaries. Allen and Unwin: Boston.

Pulotov, Saidosim, State Migration Services Official (Isfara). 2004. Interview by author, 20 September, Isfara. Tape Recording. Carleton University, Ottawa.

Radio Free Europe/Radio Liberty. 2005a. Tajik President Says No U.S. Military Bases in His Country. 23 September. Internet. Available from http://www.rferl.org/features/features_Article.aspx?m=09\&y=2005\&id=60382C8020ED-497F-8CF3-4BBB85CAD0FE; accessed 27 September 2005. . 2005b. Tajik Officer Sentenced for Drug Trafficking. 22 September. Internet. Available from http://www.rferl.org/features/features_Article.aspx?m=09\&y=2005\&id=124006D95731-446D-BA02-FADFBDF44F43; accessed 27 September 2005.

Rajabov, Mamadsaid, Resettler. 2004. Interview by author, 23 September, Vashang. Tape Recording. Carleton University, Ottawa.

Rajabov, Zafar, State Migration Services Official (Farkhor). 2004. Interview by author, 14 October, Farkhor. Tape Recording. Carleton University, Ottawa. 
Rakhimdzhanova, Sh. State Migration Services Announces Improved Situation of Resettlers in Beshkent District. Avesta (Dushanbe)13 September. (In Russian).

Rashid, Ahmed. 1994. The Resurgence of Central Asia. New Jersey: Oxford University Press.

RIA Novosti. 2005a. Military, Energy Cooperation with Tajikistan Russia's Top Priority. 4 October. Internet. Available from http://en.rian.ru/world/200510004/41591982-print.html; accessed 6 October 2005.

2005b. Main Threats to Russia's Security Come from Central AsiaExpert. 2 October. Internet. Available from http://www.en.rian.ru/russia/20051002/41574063-print.html; accessed 2 October 2005.

Nexis)

.2005c. Tajikistan a Priority for Russia, President Putin. 3 June. (Lexis

Rowland, Richard H. 2005. National and Regional Population Trends in Tajikistan: Results from the Recent Census. Eurasian Geography and Economics 46 (3): 202-223.

Roy, Olivier. 2002. Soviet Legacies and Western Aid Imperatives in Central Asia. In Civil Society in the Muslim World, edited by Amyn B. Sajoo, 123-148. New York: Routledge.

Rozikov, Oimakhmad, State Migration Services Official (Pyanzh). 2004. Interview by author,

Rushanova, Mavsuma, Returned Resettler (Derzud). 2004. Interview by author, 30 October, Derzud. Written Recording. Carleton University, Ottawa.

Rustamov, Kalangar, State Migration Services Official (Shurab). 2004. Interview by author, 20 September, Shurab. Written Recording. Carleton University, Ottawa.

Ruz I Nav (Dushanbe). 2004. Outgoing Ambassador to Tajikistan Says Regional Stability is UK's Main Goal. 26 June. (Lexis Nexis)

Sadulloev, Ozar, Resettler. 2004. Interview by author, 23 September, Vashang. Tape Recording. Carleton University, Ottawa.

Saidov, Murod, Resettler. 2004. Interview by author, 4 November, Chortimur. Written Recording. Carleton University, Ottawa. 
Salahi, Lara. 2005. Tajikistan Banks on Russia for Defense. United Press International 1 July. (Lexis Nexis).

Sattorov, Firuz, Resettler. 2004. Interview by author, 12 October, Dakhana. Tape Recording. Carleton University, Ottawa.

Sayf, Moliki. 2004. Is Beshkent a Prison for those who have Lost their Way? Najot (Dushanbe) 12 August. (In Tajik).

Scott, James C. 1985. Weapons of the Weak: Everyday Forms of Peasant Resistance. New Haven: Yale University Press.

Selobod Group, Resettlers. 2004. Interview by author, 21 September, Selobod. Tape Recording. Carleton University, Ottawa.

Shakhbur Group, Resettlers. 2004. Interview by author, 15 October, Shakhbur. Tape Recording. Carleton University, Ottawa.

Sharipov, Habib, Resettler. 2004. Interview by author, 23 September, Dashti Kon. Tape Recording. Carleton University, Ottawa.

Shingleton, William D. and John McConnell. 2001. From Tamerlane to Terrorism: The Shifting Basis of Uzbek Foreign Policy. Harvard Asia Quarterly. Available from http://www.fas.harvard.edu/ asiactr/haq/200101/0101a004.htm; accessed on 4 August 2005.

Shurab 1, Resettler. 2004. Interview by author, 20 September, Shurab. Tape Recording. Carleton University, Ottawa.

Shurab 2, Resettler. 2004. Interview by author, 20 September, Shurab. Tape Recording. Carleton University, Ottawa.

Shurab 3, Resettler. 2004. Interview by author, 21 September, Shurab. Tape Recording. Carleton University, Ottawa.

Sixty Years of Border Troops Group, Resettlers. 2004. Interview by author, 22 October, Sixty Years of Border Troops. Written Recording. Carleton University, Ottawa.

Storch, Katja, Project Manager United Nations High Commissioner for Refugees (Dushanbe). 2004. Interview by author, 29 September, Dushanbe. Written Recording. Carleton University, Ottawa.

Sultanobod Group, Resettlers. 2004. Interview by author, 7 October, Sultanobod. Tape Recording. Carleton University, Ottawa. 
Tajikistan. On the resettlement of 52 households from the city of Kulyab to Karadum, Kumsangir district, Khatlon region. Dushanbe: 31 March 2004. Resolution 135. (In Russian).

2004. Cotton Production in the Republic of Tajikistan. Dushanbe: State Statistics Committee. (In Russian).

. On the partial resettlement of the population from Jamoat Vorukh, Chorkukh, Surkh to other populated areas. Dushanbe: 20 February 2003. Resolution 71. (In Russian).

. On the gradual voluntary resettlement of young families from Gorno Badakhshan Autonomous Region to Kabodiyon and Beshkent Districts in Khatlon Region. Dushanbe: 11 January 2001, Resolution 10. (In Russian).

. On the confirmation of the regulation for the order of resettlement of households from ecologically dangerous areas. Dushanbe: 9 November 2000. Resolution 467. (In Russian).

. On the crediting of households which are subject to resettlement from dangerous areas subject to the impact of ecological processes for the period 2000 to 2004. Dushanbe: 4 August 1999. Resolution 344. (In Russian).

Thomas, Caroline and Peter Wilkin. 2004. Still Waiting After All These Years: The 'Third World' on the Periphery of International Relations. British Journal of Politics and International Relations 6 (2): 241-258.

Thompson, Niobe. 2004. Migration and Resettlement in Chukotka: A Research Note. Eurasian Geography and Economics 45 (1): 73-81.

Tojikiston (Dushanbe). 2003. How Will Those from Revad Survive the Winter in Istaravshan? 4 December.

Torbakov, Igor. 2001. Tajik-Uzbek Relations: Divergent National Historiographies Threaten to Aggravate Tensions. Eurasia Net. 12 June. Available from http://www.eurasianet.org/departments/culture/articles/eav061201.shtml; accessed 4 August 2005.

ul Haque, Ihtasham. 2005. Iran, Tajikistan Offer to Supply Electricity. Dawn (Karachi, Pakistan). 27 September. Internet. Available from:

http://www.dawn.com/2005/09/27/top3.htm; accessed 27 September 2005.

Umarov, Rakhmon, State Land Committee Official (Dushanbe). 2005. Interview by author, 25 January, Dushanbe. Written Recording. Carleton University, Ottawa. 
United Nations Development Programme. 2003._Tapping the Potential: Improving Water Management in Tajikistan. Internet. Available from:

http://www.undp.org/cc/pdf/Whatsnew/whatsnew_2004/Tajikistan_water\%20man agement.pdf; accessed 13 November 2005.

United Nations Office for the Coordination of Humanitarian Affairs. Integrated Regional Information Networks (IRIN). 2005a. Central Asia: Weekly News Wrap. 19 November. Internet. Available from

http://www.irinnews.org/print.asp?ReportID=50174; accessed 19 November 2005.

Available from

http://www.irinnews.org/report.asp?ReportID=50056\&SelectRegion=Asia; accessed 19 November 2005.

. 2005c. Kyrgyzstan-Tajikistan: Landmine Threat Along Uzbek Border Removed. 31 October. Internet. Available from http://www.irinnews.org/print.asp?ReportID=49864; accessed 19 November 2005.

. 2005d. Kyrgyzstan-Tajikistan-Uzbekistan: Working to Reduce Conflict in the Ferghana Valley. 19 September. Internet. Available from http://www.irinnews.org/print.asp?ReportID=49135; accessed 6 October 2005

2005e. Kyrgyzstan-Tajikistan-Uzbekistan: Reducing Cross-Border Water Conflict. 9 February. Internet. Available from http://www.irinnews.org/report.asp?ReportID=45458\&SelectRegion=Central_Asia ; accessed 19 November 2005.

2004. Inter-Agency Meeting on the Relocation of Families in Tajikistan. 13 May. United Nations Common Premises, Dushanbe, Tajikistan.

2002a. Minutes of the Inter-Agency/Donors Meeting. 14 August. 14:30. United Nations Common Premises, Dushanbe, Tajikistan.

. 2002b. Tajikistan: Relief Effort to Flash Flood Victims Underway. 8 August. Internet. Available from http://www.reliefweb.int/w/rwb.nsf/0/903cfb37d149a36cc1256c0f004db6f0?Open Document; accessed 11 May 2004.

Agency for International Development. 2005. USAID Budget: Tajikistan. 14 June. Internet. Available from http://www.usaid.gov/policy/budget/cbj2006/ee/tj.html; accessed 2 October 2005. 
United States. Central Intelligence Agency. 2004. World Factbook: Field ListingBudget. Internet. Available from

http://www.cia.gov/cia/publications/factbook/fields/2056.html; accessed 30 December 2005.

United States. Department of State. 2005. Background Note: Tajikistan. October. Internet. Available from http://www.state.gov/r/pa/ei/bgn/5775.htm; accessed 6 November 2005.

. Embassy of the United States of America in Philippines. 2005. Building Partnerships for Progress Official Development Assistance Increases Further-But 2006 Targets Still a Challenge. 11 April. Internet. Available from http://manila.usembassy.gov/wwwhr536.html; accessed 28 December 2005.

. Embassy of the United States of America in Tajikistan. 2005. Tajikistan in the Corridor of Reform. 11 August. Internet. Available from http://www.silkroadstudies.org/new/inside/forum/Hoagland_WPCarey.pdf; accessed 2 January 2006.

. Embassy of the United States of America in Tajikistan. N.d. Embassy Sections: Export Control and Related Border Security Assistance Program. Internet. Available from http://dushanbe.usembassy.gov/exbs.html; accessed 2 January 2006.

. Library of Congress. 2005. Jim Nichol. Tajikistan: Recent Developments and U.S. Interests. 9 March. Internet. Available from http://www.fas.org/sgp/crs/row/98-594.pdf; accessed 2 January 2006.

. N.d. Agriculture. Internet. Available from:

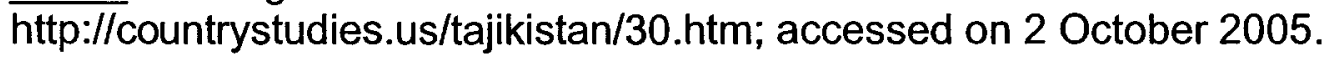

. States News Service. 2005. U.S. Assistance to Tajikistan - Fiscal Year 2005. 17 August (Lexis Nexis)

Usmonov, Islom, Ministry of Emergency Situations Official (Dushanbe). 2005. Interview by author, 14 January. Written Recording. Carleton University, Ottawa.

Vokhobov, Yakhbedzhon, Ministry of Labour Official (Dushanbe). 2005. Interview by author, 17 January, Dushanbe. Written Recording. Carleton University, Ottawa.

Weinthal, Erika. 2004. Beyond the State: Transnational Actors, NGOs and Environmental Protection in Central Asia. In The Transformation of Central Asia, ed. Pauline Jones Luong, 246-270. Ithaca: Cornell University Press. 
Wennberg, Franz. 2002. The Globality of Tajik Nationalisms - A Research Note. Central Asian Survey 21 (4): 403-410.

Werner, Cynthia. 2004. Women, Marriage and the Nation-State: The Rise of Nonconsensual Bride Kidnapping in Post-Soviet Kazakhstan. In The Transformation of Central Asia, ed. Pauline Jones Luong, 59-89. Ithaca: Cornell University Press.

White, Billy, Manager of Relief Program at Central Asian Development Agency, 2004. Interview by author, 1 September, Dushanbe. Tape Recording. Carleton University, Ottawa.

Whitlock, Monica. 2004. China-Tajik Border Opened. British Broadcasting Corporation. 25 May. Internet. Available from http://news.bbc.co.uk/2/hi/asiapacific/3745921.stm; accessed 19 October 2005.

World Bank. 6 January 2005. Republic of Tajikistan Poverty Assessment Update. Report 30853. Human Development Sector Unit. Central Asia Country Unit. Europe and Central Asia Region. World Bank: Washington.

Zaharieva, Lilia, United Nations Tajikistan Office of Peace-building Representative (Dushanbe). 2004. Correspondence by electronic mail.

Zuribekov, Zuribek, State Migration Services Official (Khorog). 2004. Interview by author, 29 October, Khorog. Written Recording. Carleton University, Ottawa. 


\section{Appendix 1}

\section{Interview Questions for Government Officials}

1. How did the presidential decrees for population resettlement come about? What was the decision process behind them? What government agencies were involved?

2. How were the resettlement programs advertised? (TV, radio, newspapers, individuals, etc.)

3. What kind of households were chosen to be resettled? Were some households turned down?

4. From which localities were households moved? Why were these places chosen?

5. To which localities were households moved? Why were these places chosen? What are the main income-generating activities in these areas?

6. What kind of assistance were households told to expect on arrival? Were migrants offered jobs? If so, what kind of jobs?

7. What is the procedure for repaying government credit? What is the procedure if migrants are unable to repay this credit?

8. What types of assistance do government agencies normally offer victims of natural disasters in Tajikistan?

9. What were the conditions of the agreement to move? Do migrants have to stay for a certain number of years, work in certain jobs, etc.?

10. How many households were moved each year? Do you have statistics that you would be willing to share with IOM on these movements?

11. Do you have any official reports that you would be willing to share with IOM on the locations and conditions of these settlements?

12. What is the process for new migrants to obtain residence permits in their new settlement area?

13. For these resettlement programs which agencies were involved, or have been involved, in providing assistance and protection?

14. Are there integration mechanisms in place fookr resettled households? Income-generating activities 
Schools

Medical services

Basic living necessities

15. What is the process for people to return to live at their original place of residence if they would so choose?

16. Are you aware of any households that have returned to their original place of residence? Explain.

17. Does Tajikistan have any specific policies governing the settlement conditions of displaced persons and policies on return to areas deemed disaster hazards?

18. Which languages are used for teaching in the schools in these new areas? What other ethnic groups are present in these areas?

19. Are there any future plans for resettlement of households in Tajikistan?

20.Are there any other important issues you would like to discuss? 


\section{Appendix 2}

\section{Interview Questions for Resettlers}

1. Biographical information
Age
Place of origin
Primary Occupation

2. When did you arrive here?

3. Reason for moving from former place of residence:

Did a natural disaster play a role in your decision to move? If so, what were your other possible options for housing besides moving under the government resettlement program?

Did the government suggest you move?

Were you given incentives to move? If so, what were the incentives? (job, house, credit, etc.) Did you move because of these incentives? Did you receive them when you resettled?

What were you expecting the economic situation in your destination area to be like?

Explain the conditions of your agreement to move - Did you agree to live in the resettlement area for a certain number of years? Did you agree to pay back loans in a certain amount of time? Would you have had to return the credit if you decided not to stay? Did you agree to a certain job here? What was your primary reason for moving here?

4. Property at place of former residence:

Were you de-registered from your previous residence?

Do you still own a house or land there?

Who is living in the house or who is using the land now?

Do you wish to move back in the future?

5. Describe the living conditions you had at your former residence.

Housing

Roofing

Structure

Flooring

Furniture

Number of rooms

Number of people living there

Number of children

Amount of land and its fertility

Water

Where did you usually get your water from?

How far was the water source from your residence? 
Electricity

Where were the latrines located?

Gas

Did you have electricity? Was there a constant supply?

What did you use to cook your food and keep warm in winter?

Where did you get it from?

Was there a constant supply?

Employment

Were you employed? If so, where?

Is your work usually part time or full time?

What was your income per month?

Education

How much were your monthly expenses?

Was there a school here?

Did your children go to school?

Food

Did you grow your own?

Did you own any animals?

Did you sell food in the market or to your neighbours?

How many meals did you usually have in one week?

Health

What did you usually eat?

Where was the nearest hospital?

How did you get there?

How much did you pay for a doctor's services?

If you needed medicine where did you get it from?

5. Arrival to new area of settlement:

Were you given a choice of places to move to?

Did you want to move here originally?

Describe any possible negative consequences that may have come about should you have chosen not to move under the government resettlement program.

What was the registration procedure when you arrived?

Do you have a propiska for your new place of residence?

Did you receive government assistance? If so, how much? What did you spend it on? Do you have to pay it back? When? For how long? Where do you go to pay it back? What is the interest rate? What if you want to move somewhere else - do you have to pay the money back before you move?

6. Housing:

Were you promised housing at your new place of residence?

Was there housing for you on arrival? If so, what condition was it in? How did you end up in this house and not any other? 
Do you own your housing here? If so, what was the procedure for taking ownership?

How many people are living in the house?

Is there electricity?

Has your housing situation improved here?

7. Water:

Where do you usually get your water from?

How far is the water source from your residence?

Do you boil the water?

Does it taste salty?

Where are the latrines?

Has your water situation improved here?

8. Gas:

What do you use to cook your food and keep warm in winter?

Where do you get it from?

Is there a constant supply?

9. Employment:

Are you employed? If so, where?

How many months have you been employed?

Is your work usually part time or full time?

How much are you paid for your work

What is your main source of income?

What is your income per month?

Has your income improved here?

How much are your monthly expenses?

Can you work elsewhere if you wanted?

Have you ever gone to find work elsewhere? If so, where and what was the result?

What is the main income-generating activity in this area? Was the development of these activities mentioned as an issue when you were discussing the resettlement program?

10. Education:

Is there a school here?

What was the procedure for registering your children in school?

Do your children go to school?

How many times a week?

11. Food:

Where do you get your food?

Do you grow your own?

Do you own any animals?

Do you sell food in the market or to your neighbours? 
How long will your current food supply last?

What do you usually eat?

Has your food situation improved here?

12. Health:

How many people in your house have been sick in the last 6 months, the last year?

What kind of sicknesses have they had?

Where is the nearest hospital?

How do you get there?

How much do you pay for a doctor's services?

When was the last time you consulted a health worker for anything?

If you need medicine where do you get it from?

Has your health situation improved here?

13. Relations with neighbours:

Do you have Uzbek or Kyrgyz neighbours?

How often do you talk to them?

How often do you help each other, borrow tools or food?

Do your children study together at school? In which languages?

14. What is the main ethnic group in this area? Was ethnicity mentioned as an issue when you were discussing the resettlement program?

15. Have you received aid from other locals or international organizations? If so, describe what kind of aid and the frequency of aid that you received.

16. Overall opinion:

Do you want to move away or stay here?

Do you want to move back to your former residence?

How do you move away legally?

17. Are there any other important issues you would like to discuss? 


\section{Appendix 3}

\section{Interview Questions for Representatives of International Organizations}

1. What types of services or programmes does your organization provide in terms of disaster reduction programs and humanitarian aid?

2. Please describe the process by which your organization decides to engage in protection and/or assistance to internally displaced persons due to natural disasters or otherwise.

3. Are you aware that the Tajik government has a concrete policy to resettle citizens within Tajikistan?

4. If so, do you have any official reports or statistics that you would be willing to share with IOM on the migration, locations and conditions of these resettlement areas?

5. Have you been involved in rendering humanitarian assistance to people in these resettlement areas? If so, please provide details. If not, why?

6. Describe your observations of the living conditions in out-migration regions, in-migration regions and the process that is used to move resettlers.

7. Are you aware of any other organizations that have rendered humanitarian assistance to people in resettlement areas?

8. Has the government or other organizations put integration assistance mechanisms in place for those who have been resettled?

Income-generating activities

Schools

Medical services

Basic living necessities

9. Are you aware of any households that have returned to their original place of residence? If so, please elaborate.

10. From your point of view, what options do these resettled households have? Can they return to their original place of residence? Can they move elsewhere? Can they change jobs?

11. What are the main income-generating activities in the areas people are being resettled? Have these activities played a role in this migration? Explain. 
12. Has ethnicity played a role in this migration? Explain.

13. Are you aware of other areas slated for moving by the government? If so, please elaborate.

14. Are you aware of any organizations and/or institutions that have specifically investigated this issue? If so, would you provide their contact information?

15. Are there any other important issues you would like to discuss? 